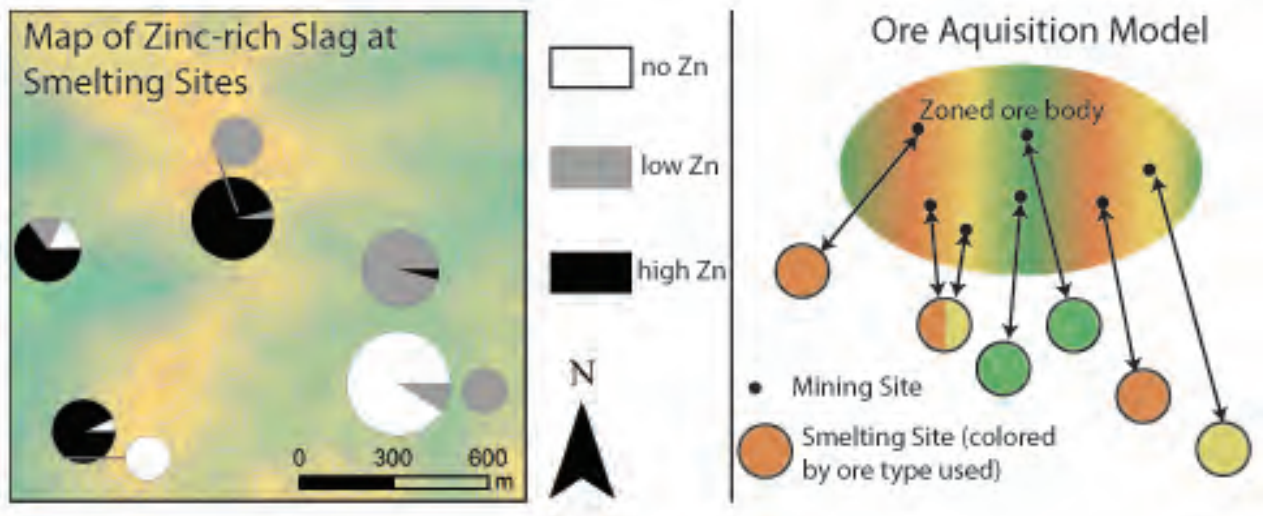




\section{Copper Production Landscapes of THE SOUTH CAUCASUS}

4 Nathaniel L. Erb-Satullo ${ }^{1}$

5 Brian J. J. Gilmour ${ }^{2}$

6 Nana Khakhutaishvili ${ }^{3}$

7

$8{ }^{1}$ Department of Anthropology, Harvard University, 11 Divinity Ave, Cambridge, MA, 02138

9 USA; nsatullo@fas.harvard.edu; Phone: 001-413-441-2331; Corresponding Author

$10 \quad{ }^{2}$ Research Lab for Archaeology and the History of Art, Oxford University, Dyson Perrins

11 Building, South Parks Rd, Oxford, OX1 3QY, United Kingdom; brian.gilmour@ rlaha.ox.ac.uk

$12{ }^{3}$ Department of History, Archaeology, and Ethnology, Shota Rustaveli State University, 10

13 Rustaveli Ave, Batumi 6010, Republic of Georgia; nana_khakhutaishvili@yahoo.com

14 


\section{Abstract}

17 Studies of metal production frequently show a correlation between scale and organizational

18 complexity. The remarkably rich landscapes of metal-producing sites of late $2^{\text {nd }}$-early $1^{\text {st }}$

19 millennium BC Colchis provide an unprecedented opportunity to reexamine this apparent

20 correlation. Investigations of copper smelting sites show that industries with a large aggregate

21 output can be the result of numerous small groups of metalworkers acting independently. Spatial

22 data on site distributions, estimates of productive output, and archaeometric data on ore

23 procurement patterns were integrated to reconstruct the organization of production. Judicious use

24 of a portable X-ray fluorescence spectrometer (pXRF) showed that not only were smelting sites

25 highly dispersed, but also that metalworkers at different sites were using ores from geologically

26 distinct deposits. This innovative approach helped to reconstruct the organization of production

27 in a distinctive metal production landscape, bridging an enduring divide between landscape-scale

28 and microscopic investigations of craft production.

33 Keywords: Craft production; landscape; survey; metallurgy; slag; smelting; Late Bronze Age;

34 Early Iron Age; GIS; Black Sea 


\section{Introduction}

Metal production systems are complex enterprises shaped by both natural and anthropogenic factors (Hardesty, 2010: 109). Geological realities constrain where ore deposits are located, and ecological factors determine where suitable fuel sources can be found. Often these areas are located in mountainous regions or in other areas of marginal agricultural potential, meaning that ore deposits are removed from both sources of labor and consumer markets. Many metallurgical technologies require specialist knowledge gained over long periods of time. These twin issues - the complexity of the production process and the spatial distribution of resources-have invited a range of different solutions, from emergent systems organized from the bottom up (Morse, 2003: 4), to highly organized expeditions by centralized authorities (Shaw, 1998).

In Western Asia, the organization of metal production, particularly bronze and iron, has figured prominently in discussions of social and technological change in the Late Bronze and Early Iron Age (LBA-EIA) (Mirau, 1997; Sherratt, 1993; Zaccagnini, 1990). The overwhelming geographical focus of research on LBA-EIA metal production and trade is the eastern Mediterranean and the Levant (Kassianidou, 2012; Knapp, 2012; Knapp and Kassianidou, 2008;

53 Liverani, 2003; Liverani, 2008; Pulak, 2008; Sherratt, 1993, 1998). Much of the scholarly debate

54 has centered on the degree of state control over trade and (to a lesser extent) production (Bell,

55 2012; Routledge and McGeough, 2009). However, though it is clear that economic activity was 56 organized by both merchant families independent of the palace and "men of the king" working

57 for the crown, the pervading viewpoint is that much trade, especially long-distance large-scale movements of materials, was organized from the top down.

Studies of LBA-EIA copper production have uncovered landscapes that bear the mark of

60 a highly centralized system of control over production. There is ample evidence of New

61 Kingdom (LBA) Egyptian presence in major copper producing areas (Rothenberg, 1987, 1988),

62 even if the nature of that presence is unclear. Despite new Early Iron Age dates from Timna Site

63 30, a site previously thought to be Late Bronze Age in date (Ben-Yosef, 2010: 567; Ben-Yosef et

64 al., 2012), it is highly likely that Egyptians exploited copper in the Timna area (Yagel et al., 65 2016). By the Early Iron Age, large fortified smelting camps were constructed at Timna and 66 Faynan (Bachmann and Rothenberg, 1980; Hauptmann, 2007; Levy et al., 2012; Levy et al., 
2014; Rothenberg, 1990; Weisgerber, 2003). These smelting sites attest to both the centralization

68 of production and the efforts to control and protect valuable resources and labor-a remarkable

69 feat if, as has been suggested, significant portions of the population remained mobile (Levy, 70 2009).

Evidence of Late Bronze copper production on Cyprus is substantial, but there are some important gaps (Knapp, 2012). While copper slags are commonly found in urban LBA contexts on the island (Courtois, 1982; Kassianidou, 2012; South, 2012; Stech, 1982; Tylecote, 1982),

74 LBA evidence of copper smelting and mining in the rural hinterlands near ore deposits is more scarce (Kling and Muhly, 2007; Knapp and Kassianidou, 2008). This is almost certainly due to modern mining, as well as the presence of large slag heaps of pre-modern, post-Bronze Age date (see Shaar et al., 2015). There is ample speculation that, especially in the Late Bronze Age,

78 Cypriot mining and smelting was a highly organized enterprise directly administered by elites in coastal centers (Knapp and Kassianidou, 2008: 144), though the ubiquity of metal production at different sites suggests centralized island-wide control is less likely (Stech, 1982: 113). It is certainly possible coastal elites directed mining and smelting activities in the interior, but the small body of evidence for LBA metallurgical activities in inland mining regions leaves open other possibilities.

Outside of the Eastern Mediterranean, very few studies have looked at the spatial and social organization of LBA-EIA copper production in Southwest Asia. Investigation of copper production landscapes in the western regions of the South Caucasus reveals an industry that defies traditional models of how large metal production industries were organized. Data from field survey and test pitting of smelting sites, coupled with a detailed reconstruction of the technology of copper production (Erb-Satullo et al., 2014; Erb-Satullo et al., 2015), provide a fundamental basis for considering questions about the spatial and social organization of copper

91 production. The large number of metal production sites, and the large quantities of production

92 debris found at each of them, allow us to merge spatial and archaeometric data in new ways. This

93 approach not only illuminates the dynamics of a metal production landscape, it also demonstrates

94 how archaeometric data can contribute to a broader understanding of social and economic

95 processes. The picture that emerges is one that differs from traditional notions about the links

96 between organizational complexity and scale of production, demonstrating that industries with 
97 large-scale aggregate output can emerge though the actions of numerous independent, small98 scale producers.

\section{Space and Social Organization in Production Landscapes}

Any attempt to reconstruct the organization of copper production must begin with a

103 discussion of the spatial parameters of the industry. Where are the ores coming from? What do

104 the spatial distribution of smelting camps and the kinds of activities taking place at them tell us

105

106 about the organization of production? How is metal distributed and where are artifacts made?

The synthesis of spatial and archaeometric data allows us to approach more complex social questions about the coordination of production. Was metal production organized from the top-down or were small groups of people exploiting many different deposits? The degree to which production was controlled (and if so, by whom) is a fundamental issue. The concepts of coordination and control are related to the concept of attached production (Costin, 1991; Earle, 1981). However, the above terms, particularly "coordination," do not assume that the producer no longer retains the "rights of alienation" (i.e. the ability to dictate how the product is distributed), a key element of some definitions of attached specialization (cf. Clark and Parry, 1990: 298). As an index of production, coordination refers to the degree to which metal production was carried out by a large group of people acting in concert towards a single goal. High levels of coordination encompass a range of different types of social organization, including both communal pooling of labor resources, as well as highly regimented mining and smelting expeditions organized from the top down (e.g. Shaw, 1998).

The extent of coordination and control has a direct impact on the spatial organization of production activities (Rochette, 2009; Zori et al., 2013). Highly concentrated smelting camps are easier to monitor. Direct visual oversight of production allows those organizing and controlling production to ensure compliance and obedience in the labor force, monitor the distribution of raw materials to workers, and increase organizational flexibility through easy communication between work parties. In the archaeological record, there are numerous instances where the concentration of production is correlated with other evidence of increased control (Levy et al., 2014; Olivier and Kovacik, 2006). Following Arnold and Munns (1994), one analytical approach for assessing the degree of control is to identify "choke-points," or key nodes along the chaîne 
128 opèratoire where a small minority could exert an outsize influence over production. In the case of 129 Arnold and Munns, while Channel Island bead production was not directly monitored by elites, 130 the importance of elite-owned canoe transportation for bead distribution meant that they exerted 131 de facto control over the industry. In the sequence of activities required to produce bronze 132 objects, there are many possibilities for this kind of horizontal integration. Rich deposits of 133 copper ores may be located deep underground, requiring significant labor to cut through 134 overlying rock. This circumstance might result in the construction of just a few, easily controlled 135 mines. On the other hand, ore may occur in numerous outcrops close to the surface, making 136 control of access more difficult. The primary smelting stage of production offers another chance 137 to exercise control over production, especially if this activity, which requires specialist skills, 138 occurred in nucleated workshops close to centers of political authority. Spatial nucleation of production activities and top-down control by political elites are not 140 strictly connected, however (Campbell et al., 2011; Costin, 2011: 112ff.). Some ecological 141 factors may push for a more dispersed pattern of production, even if it falls under the control of a 142 regional authority. A large smelting camp will quickly exhaust fuel in its immediate vicinity, so a 143 more dispersed landscape of smelting sites might reduce the amount of work required to bring 144 fuel to the furnace. Lack of external threats may result in a centrally administered production 145 system that is nevertheless somewhat dispersed (e.g. Yagel et al., 2016). A cellular model of 146 production (see Martinón-Torres et al., 2014) also permits spatial dispersion of workshops even 147 within the context of a tightly controlled industry. Conversely, Stark's (1991) study of 148 community specialization among Kalinga potters reveals how production can be concentrated in 149 certain areas, but without administrative control.

150 For these reasons, it is not sufficient merely to look at the spatial distribution of smelting 151 sites and their relative sizes. In addition, the patterns of behavior at these sites must also be 152 examined. Distance unavoidably attenuates the ability to control both end products and labor, 153 and increases the cost of maintaining that control (Costin, 1996: 212). However, it is conceivable 154 that controlled, or at least coordinated, enterprises might be scattered in different locales. 155 Spatially dispersed yet highly controlled production landscapes may show a high degree of 156 coordination in production activities, such as the types of ores used, the standardization of tools, 157 or a homogeneous set of production practices. Highly organized, tightly controlled industries 158 may be dispersed for some stages of production, but it is very unlikely that they would be 
dispersed at all stages of production. It is also crucial to consider the possibility that loose networks of independent metalworkers may share techniques and practices (through apprenticeship or other informal forms of knowledge sharing), producing a common technological style in an industry where daily activities were nonetheless carried out 163 independently.

With few exceptions (Thornton, 2009a, 2009b), typical treatments of metal production in the Near East have focused on situations where there is a high degree of correlation between

166 concentration, top-down organization, and scale (e.g. Ben-Yosef, 2010: 889). In contrast, there is

167 little investigation of cases in which scale, nucleation, intensity, and elite oversight are not 168 correlated. The following analysis of Colchian bronze production closely examines the 169 relationship between the spatial distribution of activities, and other evidence of top-down coordination. Integrating chemical and spatial data, this approach not only examines spatial proximity of sites, but also considers coordination through the lens of ore procurement networks.

This data integration overcomes a long-standing challenge for archaeometallurgical research. Spatial and chemical/mineralogical data are rarely integrated on a large scale in the

174 study of metal production. In large part, this is due to a mismatch between the two types of data.

175 Chemical and microscopic analyses identify patterns on the micron scale. The mode of analysis 176 is often intensive by necessity — chemical and microscopic analyses require significant time and 177 money to prepare. Moreover, the destructive nature of some analyses discourages large sample 178 sizes. Large robust datasets, such as in lead-isotope studies of Mediterranean copper ores and 179 bronze artifacts, take years to produce (Gale, 1999; Gale and Stos-Gale, 1982; Stos-Gale et al., 180 1997). In addition, the ephemeral nature of some production activities and the difficulties of 181 correctly identifying production debris in the field contribute to small sample sizes from most 182 excavations. As a result, these kinds of data are rarely synthesized to address broad systemic 183 questions (for excellent exceptions to this general pattern, see Bray et al., 2015; Bray and 184 Pollard, 2012; Perucchetti et al., 2015).

185 In contrast, studies of ancient landscapes are by definition extensive. Scales are measured in meters and kilometers, six to nine orders of magnitude greater than the scale of slag

187 microscopy. Integration of intensive and extensive datasets at wildly differing scales poses a 188 serious challenge. However, overcoming the tyranny of (very small) distances offers a chance to examine previously invisible patterns of behavior and address questions of broad anthropological 
relevance (i.e. questions at the human scale). Despite its enormous potential, archaeometallurgical research has largely failed to do this (Killick, 2015; Martinón-Torres and Killick, in press).

The exceptionally rich metal production landscapes of the South Caucasus present an opportunity to integrate micro-scale and macro-scale datasets, answering key questions about the spatial and social organization of production. Building on an essential foundation of microscopic and chemical analyses (Erb-Satullo et al., 2014; Erb-Satullo et al., 2015), we used rapid qualitative chemical analyses to generate large sample sizes, revealing spatial patterns in the oreuse taking place at different sites, and reconstructing the organization of production.

\section{Survey and Analysis of Copper Smelting Sites in Ancient Colchis}

Between 2010 and 2014, a series of surveys were carried out to explore metal production landscapes in western Georgia, a region known to the Greeks as Colchis, and possibly Kulkha to the Urartians (see Melikishvili, 1962). Soviet-period survey and excavation uncovered a large number of metal production sites (Gzelishvili, 1964; Khakhutaishvili, 1976, 1977, 2009 [1987]), but without the benefit of modern GPS, mapping capabilities were limited. In the denselyvegetated subtropical landscape, traditional systematic survey techniques were ineffective at locating small smelting sites, so the knowledge of local villagers and Soviet-period field notebooks were the primary tools for relocating known sites and find new ones. Both copper and iron smelting sites were located, though the earliest dated iron smelting site in our current project dates to the mid-late 1st millennium BC (see Erb-Satullo et al., submitted). This paper focuses on the copper smelting landscapes of the Late Bronze and Early Iron Age (c. 1500-600 BC). Copper smelting sites were mapped in all the areas investigated during the Soviet period, illustrating the broad regional extent of the industry (figure 1). Late Bronze and Early Iron Age copper smelting was likely carried out in a more or less continuous band through the foothill regions of the Greater and Lesser Caucasus range. This complex of sites almost certainly extends eastward along the southern shore of the Black Sea, as the Eastern Pontides are also extremely rich in metal deposits (Lutz et al., 1994; Seeliger et al., 1985).

Because mapping a few sites in a number of different areas reveals little about the local spatial organization, survey efforts were concentrated in the Supsa-Gubazeuli area, in order to 
221 examine the spatial organization of copper production in detail (figure 1). Three seasons of 222 fieldwork (2010, 2012, and 2014) identified 49 metal production sites. Radiocarbon dating of the 223 sites shows that this landscape was active for a period 300-500 years between about 1300 and 224800 BC (Erb-Satullo et al., submitted). While not all previously known sites were relocated, the 225 distribution likely represents a good approximation of the actual smelting landscape within the 226 areas investigated. The two most striking features of the smelting site distribution are the density 227 of smelting sites within the area surveyed, and the lack of clustering. This distribution alone 228 suggests that any attempt to coordinate or control production on this scale would have faced 229 serious challenges. Sites are scattered across numerous small ravines and ridges, making travel 230 between them challenging. Given the extent of modern vegetation and topography, it is rare to be 231 able to see one site from another unless they are very close. It is difficult to estimate the level of 232 vegetation in the LBA-EIA, given that most paleoecological research in the area has focused on 233 coastal zones (Connor et al., 2007; Janelidze, 2007; Janelidze and Tatashidze, 2010). The thick

234 forests, which today are found slightly higher in the foothills immediately to the south of the 235 survey area, probably extended to lower elevations in the Bronze Age. Large-scale land 236 clearance for tea plantations dates to the $20^{\text {th }}$ century. Even when modeling a landscape with no 237 vegetation, intervisibility of sites is low for sites that are so close together (figure 2). Of the 1128 238 possible site pairings ${ }^{1}$, only 105 pairings are intervisible (9\%), assuming an observer and target 239 height of $2 \mathrm{~m}$ above the ground surface. When one excludes site pairings that are over $1 \mathrm{~km}$ 240 apart, the proportion of intervisible sites is only 49 of 281 (17\%). Many pairs of proximate sites 241 are not intervisible (e.g. Sites 20, 40 and 41; Sites 45 and 46; Sites 25 and 47; Sites 25 and 24). If 242 one assumes that it is easier to control dispersed labor parties if nearby sites are intervisible and 243 within shouting distance, it follows that the topography of the Supsa-Gubazeuli production area 244 inhibits coordination between dispersed groups. In other words, it is not only the dispersed 245 distribution of the sites that makes them more difficult to control, it is their arrangement within 246 the specific topographic and ecological environment of the Caucasus foothills. It is nonetheless 247 important to recognize that intervisibility and proximity are not direct indices of coordination 248 and top-down organization. Lack of intervisibility between smelting parties does not preclude

\footnotetext{
${ }^{1}$ Site 34, located in the Vakijvari gorge, was excluded from this analysis since it is far removed from the other sites. This analysis assumes that all sites are contemporary. While there is good evidence that virtually all these sites date to the LBA-EIA (Erb-Satullo et al., submitted; Khakhutaishvili, 2009 [1987]), they were probably not all in operation at the same time.
} 
coordination - after all, the distances in question are not large. However, the distribution of these

250 sites within the landscape would have imposed challenges for any attempt to manage production, 251 ensure compliance, and maintain control over a dispersed workforce.

252 It is worth comparing the Colchian site distribution with that of Late Bronze Age copper 253 smelting in the Timna Valley (Yagel et al., 2016). Like the Colchian case, LBA smelting sites in

254 Timna are small (relative to later EIA sites) and somewhat dispersed. However, Yagel et al.

255 argue that the spatial positioning and character of Timna Site 3 suggest that it served as an

256 administrative center for other sites in the vicinity. None of those elements are present at

257 Colchian sites, which are remarkably homogeneous in character.

258 In addition to their spatial distribution, the second main feature of the sites is their small

259 size. No excavated site in the Supsa-Gubazeuli region contained more than two furnaces, and

260 slag heaps are generally only 10-20 m in diameter. Data collected from test pits can be combined

261 with earlier, more extensive excavations during the Soviet period to approximate the scale of

262 production at each site. As quantities of slag are proportional to the amount of labor involved,

263 such calculations also put rough constraints on the number of people involved in production and

264 the duration of occupation.

265 Published details from earlier Soviet projects (Khakhutaishvili, 2009 [1987]) provides

266 usable information about the total size of slag heaps at a number of sites. Often, the excavator

267 reported the approximate area of the waste dump and the maximum depth of the slag heap. In

268 addition, the excavator sometimes reports the number of cubic meters of slag recovered during

269 excavation. Gilmour (2009) assumes about 10 tonnes of slag for every 6.6 cubic meters of slag

$270 \quad\left(\sim 1500 \mathrm{~kg} / \mathrm{m}^{3}\right)$ as reported by David Khakhutaishvili. An alternative method involves calculating

271 the volume of the slag heap from reported area and maximum depth figures (approximating its

272 shape as a generalized cone), then multiplying that volume by the empirical value of

273 approximately $470 \mathrm{~kg}$ of slag per cubic meter of slag heap calculated during testing of Site 43 in

$2742012 .^{2}$ Both of these methods provide only coarse approximations, but their roughly equivalent

275 results are encouraging (table 1). Averaging the slag quantities at all sites for which the whole

276 slag heap is quantified (i.e. excluding those figures, such as Mziani III,1 where information is

\footnotetext{
${ }^{2}$ Note that this is not comparable to the other figure of $1500 \mathrm{~kg}$ per cubic meter of slag. The higher figure refers to the density of slag only, while the lower one refers to the density of unexcavated slag heap, which includes sediments and voids in the slag heap matrix.
} 
277 only available for one part of the slag heap), gives values of roughly $13,000 \mathrm{~kg}$ (calculation 1) 278 and $17,000 \mathrm{~kg}$ (calculation 2).

279 Estimates of total slag quantities can be used to estimate how many cycles of copper 280 production took place at each site. Technological reconstructions of the copper smelting process 281 (Erb-Satullo et al., 2014; Erb-Satullo et al., 2015) have shown that slag was produced in two 282 distinct stages of production. One (probably earlier) stage produced dense slag cakes left to cool 283 in the furnace, while the other (most likely later) stage of production produced spongy masses of 284 slag formed from scraping or pouring molten slag from smaller reaction vessels. Each slag cake 285 therefore corresponds to one furnace firing. The average diameter of measured slag cakes was 286 about $24 \mathrm{~cm}(\mathrm{n}=28)$. Thickness was more difficult to measure because full sections of slag cakes 287 were rarely preserved, but one example measured $7 \mathrm{~cm}$. Slag cake densities were measured 288 empirically on four samples, with an average density of $4.1 \mathrm{~g} / \mathrm{cm}^{3}$. Modeling the shape as a 289 cylinder, and assuming that roughly $10 \%$ of the slag cake volume consists of gas bubbles, gives a 290 cake mass of about $12 \mathrm{~kg}$. Estimating the mass fraction of slag cakes as a proportion of total slag 291 at a site is difficult. Attempts to quantify this figure using data from small test pits yielded wildly 292 varying values, from less than 0.1 to greater than 0.9 , reflecting the simple fact that spongy slags 293 and dense slags were often deposited in different parts of the site. An intermediate value of 0.6 294 was chosen for this analysis, meaning that a site with an estimated 15,000 $\mathrm{kg}$ of slag would 295 represent about 770 slag cakes and an equivalent number of furnace firings.

296 If one speculates that these smelting sites were in use for at least a generation of 20-25 297 years, this amount of slag represents an upper bound of 30-40 firings per year. Even accounting 298 for time taken for the production of charcoal, mining, and the stages of production that produced 299 spongy slag, this represents a fairly modest undertaking well within the capabilities of a small 300 group of metalworkers smelting for only part of the year. These final calculations of annual 301 output involve substantial assumptions, but the figures suggest that the labor required to produce 302 the amount of slag at each site would not have required a large expedition.

303 Quantities of slag at individual sites can also be used to make very approximate estimates 304 about the aggregate output of the industry. Assuming an average of about 15,000 kg (15 metric 305 tons) of slag per site, the 49 sites identified in the Supsa-Gubazeuli area represent about 735 tons 306 of slag. The reported 400 sites mentioned by Khakhutaishvili (2009 [1987]: 17) in the four areas 307 he studied would be roughly equivalent to 6000 tons of slag. But as we have already discussed, 
the small size of the sites, and the densely vegetated landscape probably means that this figure is a gross underestimation of the total number of sites. Anecdotal evidence (e.g. Site 34) strongly suggests that the landscape of copper smelting sites extends up into the densely wooded copperrich mountains immediately to the south of the study area. Mountainous areas of southwestern

312 Georgia are almost totally unexplored in this regard, and the same is true of the Greater Caucasus 313 regions of Svaneti, Abkhazia, and Racha. Nevertheless, work conducted by local archaeologists 314 in these regions unequivocally shows that they were also major centers of metal production 315 (Chartolani, 1989: 158-166; 2001; Chernykh, 1992: 275-276; Iessen and Degen-Kovalevskiy, 316 1935; Maisuradze and Gobedzhischvili, 2001; Mudzhiri, 2011; Sulava, 2001). While the 317 individual output of any particular smelting site was rather small, the aggregate output of the 318 Colchian copper smelting industry was quite extensive. These figures allow order-of-magnitude comparisons with contemporary sites.

320 Excavation of Politiko Phorades, an early LBA (1650-1500 BC) site in Cyprus, recovered more 321 than 3.5 tons of plano-convex slag cakes, or roughly equivalent to $3200-3500 \mathrm{~kg}$ (Knapp and 322 Kassianidou, 2008: 142). These values are on the same order of magnitude as many individual 323 slag heap size estimates for the Supsa-Gubazeuli area. The excavators argue that the scale of 324 production at Politiko Phorades does not support a centralized enterprise, but note that such 325 organization probably existed in the later part of the LBA (Knapp and Kassianidou, 2008: 144). 326 Total values in the range of about 4 million tons of slag (Constantinou, 1982: 22; Kassianidou, 327 2013: 37) do not distinguish between Bronze Age slag heaps and later pre-modern exploitation 328 (Ben-Yosef, 2010: 87; see also Shaar et al., 2015).

329 In contrast to the somewhat ambiguous evidence on Cyprus, Early Iron Age smelting 330 sites in the southern Levant show clear evidence for large-scale production. By one estimate, 331100,000 to 130,000 tons of slag were produced in just four Iron Age sites in Wadi Faynan 332 (Hauptmann, 2007: 147), with 50,000-60,000 tons at Khirbet en-Nahas alone (Levy et al., 2004: 333 867). The quantity of early Iron Age production debris on the western side of the Arabah is 334 smaller, through still substantial (Ben-Yosef, 2010: 617). Smelting camps at Bir Nasib in the 335 Sinai, dated to the LBA and possibly earlier, contained as much as 100,000 tons of slag 336 (Rothenberg, 1987). More recent work has suggested that early estimates of slag quantities might 337 be an overestimate, since slag heaps, at least at Khirbet en-Nahas, are only about $40 \%$ slag by 338 volume (Ben-Yosef, 2010: 338). Nevertheless, the scale of production at the larger sites in the 
Southern Levant is three orders of magnitude greater than any single contemporary Colchian

340 smelting site. Accurate comparisons of aggregate output of all smelting sites in the two regions

341 are challenging, because the Southern Levant has been the subject of more intensive research,

342 and the arid landscape makes large sites easier to find. By comparison, the small site size, less

343 intensive research, and lush subtropical landscape would all suggest an underestimation of the

344 Colchian bronze industry relative to the Southern Levant. It is conceivable that, in aggregate, the

345 actual scale of production was comparable in both areas.

346 The previous discussion has intentionally used slag rather than metal as the proxy for

347 industrial output. It is very difficult to move from quantities of slag to quantities of metal

348 produced, especially for copper smelting operations. The composition of the ore and

349 technological decisions (such as fluxes used) will significantly affect these ratios. For the Faynan

350 region, which contains mostly copper oxide ores, estimates run on the order of 10:1 for

351 slag:metal ratios (Hauptmann, 2007: 253). Similar ratios are used to estimate the quantity of

352 metal produced at Politiko Phorades (Knapp and Kassianidou, 2008). However, different ratios

353 of slag:metal have been suggested, from 3.75:1 (Maldonado and Rehren, 2009: 2004) to the

354 radically different ratio of 1:6 (Shalev et al., 2006). While there is relatively good qualitative

355 information about the ore sources used in Colchis, there is simply not enough quantitative data to

356 estimate slag:metal ratios.

357 It is worth asking how much fuel, and correspondingly, how much woodland, would have

358 been required to support this industry. Calculating the acreage of trees required to produce a

359 given quantity of slag is challenging, and depends on the richness of the ore, metal production

360 technologies, charcoal-making practices, wood harvesting strategies, and local ecologies (Straka,

361 2014; Wertime, 1983: 451). As a result, the following calculations should be treated as very

362 approximate. Wertime, calculating the area of forest cut to produce 1 ton of slag, estimates 0.5 to

3631.5 acres per ton for Mediterranean metal production, with Cyprus on the upper end of that range

364 due to its relatively low-grade ores (Wertime, 1982: 357; 1983: 451-452). Given the wetter

365 climate and denser vegetation of the Eastern Black Sea region, 1.5 acres per ton of slag seems to

366 be a reasonable upper bound for the Colchian case. Assuming an average of 15,000 kg (16.5

367 tons) of slag per site, these calculations yield about 25 acres of forest per site, equivalent to an

368 area with a radius of about $175 \mathrm{~m}$. For all the sites mapped in the Supsa-Gubazeuli area, the total

369 forest area required is just under $5 \mathrm{~km}^{2}$. If the wetter climate resulted in higher productivity in 
370 terms of charcoal per acre of forest, and 0.5 acres of trees per ton of slag is closer to the true

371 figure, then the 49 sites of the Supsa-Gubazeuli region correspond to the clearance of just 2.5

$372 \mathrm{~km}^{2}$. Both figures are significantly less than the roughly $8-9 \mathrm{~km}^{2}$ over which the sites are

373 distributed, and forest regeneration may have significantly reduced the total amount of land

374 cleared during the period that these sites were active. The fuel demands of the industry

375 undoubtedly impacted the local ecology, and exhaustion of adjacent stands of trees may have

376 prompted the relocation of smelting sites, as has been documented ethno-historically in Anatolia

377 (Yener, 2000: 78). Indeed, environmental records from settled areas near the coast show

378 evidence of anthropogenic burning and land clearance around the $1^{\text {st }}$ millennium BC, though in

379 this case, metallurgy is not directly implicated (Connor et al., 2007: 31-33). However, these

380 calculations make it reasonably clear that the fuel demands of this smelting landscape did not

381 exceed the capacity of the immediately surrounding forest, and most fuel could have been

382 brought from very nearby, perhaps less than $200 \mathrm{~m}$ away. This means that the labor requirements

383 for procuring and transporting fuel were far less than for a large centralized site operating over a

384 long period, which would have quickly exhausted the closest stands of trees.

\section{Ore supply and the Organization of Mining}

The size and distribution of smelting sites suggest a lack of coordination and top-down control of production activities. However, leaping immediately to this conclusion risks casually conflating lack of concentration with lack of coordination and control. As discussed above, there are circumstances where an industry organized from the top down might still have a high degree of dispersion. Indeed, a cursory examination of production remains shows broad similarities in technological style between sites. Are these commonalities indicative of large-scale coordination, or are they merely reflective of a common technological style among independent producers?

In order to address the question of whether metalworkers at each site were acting independently, it is necessary to take a closer look at the activities taking place at each site. Are metalworkers smelting ore mined from a single location, or are they using ores gathered from multiple sources? The former case would indicate a greater degree of coordination and perhaps control of the metal production sequence, even if smelting sites were highly dispersed. Iron mining by the Toro of Uganda provides a fitting ethnographic example of such an arrangement 
401 (Childs, 1998). Iron mines were controlled by their discoverers, who allotted mining rights to

402 family members and other associates. The iron ore was processed in different smelting

403 workshops, but the original discoverer of the mine held considerable power over access to the

404 deposit. Could such a model apply to the Colchian case? Fortunately, the chemical and

405 mineralogical composition of the slag reflects variations in the original ore sources (Erb-Satullo

406 et al., 2014), making it possible to distinguish ores gathered from different mines.

407 This approach naturally requires a strong understanding of the ore sources, their

408 compositional variation, and their parageneses (formation of associated non-ore minerals). The

409 Eastern Pontic and Lesser Caucasus mountains are known for a wide variety of metallic deposits,

410 including porphyry, volcanogenic massive sulfide and vein-type deposits (Gugushvili et al.,

411 2010; Moon et al., 2001). In Southwestern Georgia, copper and other polymetallic deposits are

412 typically associated with syenitic and dioritic intrusions in andesitic host rock (Erb-Satullo et al.,

413 2015: 272-273; Nazarov, 1966). The deposits in the Merisi region, consisting primarily of

414 copper, silver, lead and molybdenum, have been best recorded (Gugushvili et al., 2010: 339), as

415 they were briefly exploited during modern times (Ghambashidze, 1919: 88; Nazarov, 1966: 117).

416 The likely source of the ores smelted at the Supsa-Gubazeuli sites is the stock batholith intrusion

417 in the upper reaches of the Bzhuzhi and Vakijvari gorges, some 10-15 km away. This massive

418 intrusion into andesitic host rock probably opened up numerous fissures in the host rock,

419 allowing ore bearing fluids to form numerous small, but potentially rich metal veins. This pattern

420 is confirmed by Soviet-period geological surveys of nearby copper deposits (Gabunia, 1933:

421 556-557) (figure 3). Ore bodies such as this may vary chemically and mineralogically, a

422 phenomenon known as zonation. Evidence of zonation is reflected in Gabunia's descriptions,

423 with some copper deposits listed as having associated sphalerite ((Zn,Fe)S), galena (PbS), pyrite

$424(\mathrm{FeS})$, and hematite $\left(\mathrm{Fe}_{2} \mathrm{O}_{3}\right)$.

425 Laboratory analysis of the smelting slags showed that paragenetic mineral and chemical

426 variation was translated to the slag in the smelting process (Erb-Satullo et al., 2014; see also

427 Tylecote et al., 1977) (figure 4). Differences in zinc, deriving from sphalerite, were clearly

428 observed in both chemical and mineralogical analyses.

429 New trace element analyses of slag via powder WDS-XRF suggest that zinc-bearing

430 sphalerite was not the only paragenetic mineral that varied between different ore deposits (table

431 S1 in online supplementary material). The plot of molybdenum vs. cobalt, both of which are 
432 elements commonly associated with copper deposits, illustrates this point effectively (figure 5).

433 High cobalt content tends to correlate with low molybdenum, and vice versa. In addition,

434 chemical compositions are relatively consistent within sites. Samples from Site 5 have up to

4352939 ppm Co, but never more than 630 ppm Mo. Likewise, samples from Site 3 have up to 1449

436 ppm Mo, but never more than 705 ppm Co. The linear spread in samples from the same sites

437 (most obvious for Sites 3, 5, and 38) is likely due to volatilization or admixture of other material

438 during the smelting process. Importantly, none of these samples have appreciable $\mathrm{Zn}$ content.

439 High Zn samples from Site 8 all cluster together with very low Co and Mo. These results

440 demonstrate that there were likely many different types of ore deposits being exploited, with

441 varying combinations of $\mathrm{Zn}$, Mo, Co, and probably other elements. ${ }^{3}$ Not all ore differences

442 translate to the slag as well as zinc, but that does not mean that they did not exist.

443 Despite the clear evidence that differences in slag chemistry and mineralogy reflect

444 differences in ore sources, there are some challenges to this analysis. These deposits were not

445 mined in modern times, and many are located in steep, densely forested gorges with no modern

446 settlement and no easy means of access. Thus, it was not possible to locate and sample ancient

447 mines directly to demonstrate that the differences are between mining sites rather than within

448 mines. However, several lines of evidence point to the former case. Geological surveys do report

449 paragenetic variation between nearby copper deposits, mentioning sphalerite $((\mathrm{Zn}, \mathrm{Fe}) \mathrm{S})$ as an

450 accessory mineral in some but not in others (Gabunia, 1933: 556-557). Moreover, the consistent

451 chemical and mineralogical differences between slags from different smelting sites (figure 5)

452 (Erb-Satullo et al., 2014: 153-156) also suggest these major ore variations were mostly between

453 mines, not within them. Otherwise, we would expect to see more homogenous assemblages of

454 slag compositions at different sites. Thus, while some variation within mines is possible, the

455 large differences in the presence and absence of key elements almost certainly reflect the 456 exploitation of distinct deposits.

457 Still, there are limits on the extent to which mines can be distinguished. Nearly all 458 textural and mineralogical information about the ores, which might have allowed more fine459 grained differentiation, has been destroyed or severely compromised by the high temperatures of 460 the smelting process. Similarly, more subtle chemical differences have also been obscured.

\footnotetext{
${ }^{3} \mathrm{Ag}, \mathrm{Pb}$, and $\mathrm{Cr}$ are additional possibilities. Minute inclusions of lead and silver sulfides were noted in one or two slags. Trace lead and chromium concentrations do vary somewhat by site. Silver content was not measured.
} 
461 These circumstances place limitations on the ability to distinguish different ore sources. For 462 instance, there may have been many different deposits of zinc-rich ores that were exploited, but 463 distinguishing between them using slag analysis is challenging.

$464 \quad$ Keeping in mind these limitations, careful use of the portable X-ray fluorescence 465 spectrometer ( $\mathrm{pXRF}$ ) permitted the rapid qualitative analysis of a large number of slags, making 466 it possible to map spatial patterns in ore acquisition and assess to what extent metalworkers were 467 acting in concert to acquire ore. 691 slag samples were analyzed from 39 of the 49 sites 468 surveyed. Analysis of the spectra focused on two elements clearly associated with paragenetic 469 mineral variation in the original ore deposits, $\mathrm{Zn}$ and Mo. Spectra were classified as having large, 470 small, or no peak in the X-ray spectrum, corresponding to high, low and no quantities of $\mathrm{Zn}$ and 471 Mo. For additional information about the pXRF methodology, especially the methods of 472 classifying peaks, see Appendix A (supplementary material).

473 Qualitative pXRF analysis permits testing of two distinct models of ore acquisition 474 (figure 6). In the coordinated mining model, mining expeditions were organized by local elites, 475 and then ores were smelted in separate camps. If this were the case, we would expect 476 contemporary sites to have used the same types of ores, and exploitation of multiple types of ore 477 at a single site should be fairly minimal. If multiple types of ore are exploited at single sites, one 478 should expect the ore-use profile to be broadly consistent between contemporary sites.

479 On the other hand, in the independent mining model, multiple groups of miners extracted 480 ore from a constellation of mining sites. In this case, contemporary sites would have dramatically 481 different ore-use profiles. This model encompasses both situations where metalworkers at a 482 particular smelting site exploited ores from one source, and cases where metalworkers used ores 483 from multiple deposits. The latter case might indicate that the people carrying out the smelting 484 received ores from multiple groups of miners, or, if the miners and the smelters are the same 485 people, that different ore deposits were exploited during different mining campaigns.

486 The results of a large pXRF survey show some intriguing patterns on both an intra- and 487 inter-site level. For sites where samples were taken from a number of different contexts, the data 488 show a general consistency between different contexts on the same site (figure 7). This is 489 especially clear for the zinc data. Generally, if a site has a high proportion of zinc-rich slags (e.g. 490 Site 28), that high frequency is seen across a range of contexts. On the other hand, some sites 491 have no high zinc slags, despite the fact that multiple contexts were sampled (e.g. Sites 5 and 
46). Only Site 43 showed a marked difference between surface collected slags and those from test pit contexts, suggesting that multiple ore sources were exploited by metalworkers at the site.

The data for the presence and absence of molybdenum show the same relative consistency between different contexts at the same site. Compared with the data for zinc, however, the patterns are less clear. Several explanations may account for this difference. Even in high molybdenum samples, the absolute concentration of molybdenum is less than that of zinc, meaning that the tripartite categorization signifies a finer scale of differentiation (see Appendix A in online supplementary material). The smaller absolute quantities of molybdenum in the slag (and, correspondingly, the ore), mean that smaller variations are required to shift the sample to another qualitative category and obscure the translation of the ore pattern to the slag. It is also unclear how molybdenum content is affected by smelting, since available experimental data does not discuss that element (Tylecote et al., 1977). Interestingly, very few samples had a high content of both molybdenum and zinc. Among the samples with low or no zinc, however, there are large numbers of samples both with and without high molybdenum.

These intra-site comparisons point to several conclusions. The results suggest that variability found in surface collected slags are reasonably good approximations of the range of ores being smelted at the site, though surface collections likely contain a wider range of variation than small test pits. The data on molybdenum variation may point to the same conclusion, though the smaller absolute variation and outstanding questions about partitioning make this dataset somewhat less reliable. The likely use of ores from distinct mining locales could be the result of exploiting different outcrops in different years of seasonal work.

Maps of ore-derived variations in slag chemistry reveal significant patterns. Maps were produced based on zinc data alone, molybdenum data alone, and a combination of the two. The zinc map reveals striking differences in the use of zinc-rich ores between different sites (figure 8). A number of sites with large sample sizes (e.g. 5, 46, 25, and 41) have no high-zinc slags, indicating that they were exploiting ore deposits with little to no zinc. This is a striking contrast to other sites (e.g. 8, 14, 24, 28, and 29), where the majority of slag samples are rich in zinc.

Moreover, there is very little spatial correlation between sites using zinc-rich ores and sites using zinc-poor ores. High-zinc slags are found at slightly higher frequencies in the southwest portion of the survey area, while low and no-zinc slags are slightly more common in the northeastern part, but this is not a sharp distinction. This slight pattern is likely a reflection of 
523 proximity to ores of different types. Zinc-rich ore deposits may be closer to the smelting sites in 524 the southwestern area, while zinc-poor ores are probably more common in areas closer to the 525 northeastern part of the survey area.

526 Remarkably, different ore types were often used at sites in very close proximity to one

527 another. For instance, metalworkers at Site 14 exploited large amounts of high-Zn ores (15 of 16

528 samples), while neighboring Site 36, located about $100 \mathrm{~m}$ away, apparently did not (0 of 8

529 samples). The data are even more compelling for Site 27 and 28, which have larger sample sizes

530 and are about $90 \mathrm{~m}$ from one another. Only 1 sample of 46 at Site 27 was categorized as zinc-

531 rich, while 31 of 47 samples were zinc-rich at Site 28. These comparisons strongly suggest that

532 these proximate sites were not part of a larger, coordinated mining expedition. Spatial proximity

533 of sites using the same ore sources is a key prediction of the coordinated mining model. The lack

534 of this spatial patterning is further indication that mining and smelting were conducted by

535 multiple independent groups of miners and metalworkers. Some of these pairs of proximate sites

536 may have been occupied sequentially. Metalworkers probably did not build new workshops

537 every season, but they may have shifted sites of production between different generations. At

538 that point, the veins or outcrops exploited by the earlier generation of metalworkers may have

539 been exhausted, prompting a change in ore source.

$540 \quad$ Radiocarbon dating supports the independent mining model, showing that sites exploiting

541 zinc-rich and zinc-poor ores were in operation at about the same time (for detailed discussion of

542 chronology, see Erb-Satullo et al., submitted). Two wood charcoal samples from Site 28 were

543 dated to $996-842$ calBC (95\% confidence) and 1026-836 calBC (95\% confidence), while a single

544 charcoal sample from Site 27 produced a date of 1016-839 calBC (95\% confidence). Sites 5 and

5458 also date to the same period, yet have dramatically different ore-use profiles. Two charcoal

546 samples from Site 5, which had no high zinc slags among the 46 analyzed, yielded dates of 970-

$547961 ; 935-822$ calBC (95\% confidence) and 908-812 calBC (95\% confidence). Two samples from

548 Site 8, a site with abundant zinc-rich slags, were dated to 915-815 calBC (95\% confidence), and

549 1086-903 calBC (95\% confidence). These dates do not prove that metalworkers were operating

550 these sites at exactly the same time, as each site was probably not occupied continuously for

$551100+$ years. Nevertheless, the dating does show that the exploitation of zinc-rich and zinc-poor

552 ores were not separated by hundreds of years. Importantly, these results contradict the

553 predictions of a coordinated mining model. 
The spatial patterning of molybdenum-rich samples reveals generally similar patterns

555 (figure 9). There are some inter-site differences in the molybdenum content (compare Sites 5, 8, 556 27, and 29), but these differences are not as sharp as in the zinc data. Mapping patterns of zinc 557 and molybdenum data together (figure 10) revealed additional patterns, suggesting a greater 558 diversity of mining sites. While zinc-rich slags are slightly more common in the southwestern parts of the survey area, zinc- and molybdenum-rich slags, though rare overall, are more common in the northeast. Similarly, the combined dataset suggests that there may be different kinds of zinc-poor deposits, as evidenced by the differing molybdenum content in zinc-poor slags at Sites 5 and 41. In conjunction with the WDS-XRF trace element analyses on the more

563 limited sample, these results hint that the number of mining sites almost certainly exceeds the

564 capacity of the available methods to distinguish them. It is highly likely that zinc-rich ores from one site likely came from a different mine than zinc-rich ores from another site.

Results from the large-scale qualitative $\mathrm{pXRF}$ analysis of slags have crucial implications

567 for the spatial and social organization of mining and smelting. Combined with the spatial

568 dispersion of the smelting sites, the evidence that metalworkers were using ores from different mining sites points to the conclusion that primary production was carried out independently by different groups of people (figure 11). Though they may have shared technological practices, evidence for more sustained coordination or top-down organization in raw copper production is minimal. Still, questions remain about the organization of production elsewhere in the chaîne opèratoire of bronze production. Is there evidence that artifact production was nucleated and perhaps controlled by certain social groups? Answering this question requires an analysis of secondary production sites.

\section{The Organization of Secondary Production}

Archaeological evidence shows that raw copper, and in some cases alloyed bronze, was

580 transported from smelting sites to settlement sites for casting and forging into artifacts.

581 Numerous bronze hoards have been found in the region (Lordkipanidze, 2001: Fig. 1). The

582 hoards include both finished artifacts as well as pieces of raw metal in the form of ingots, ingot

583 fragments, or amorphous lumps of metal. Mostly, the unformed metal is unalloyed copper

584 (Abesadze and Bakhtadze, 2011 [1988]: 362-365). These analyses suggest that most copper was 
585 alloyed in the later stages of production, just before casting into metal. This data conflicts with 586 the clear evidence that some alloying did happen at primary smelting sites, earlier in the 587 production sequence (Erb-Satullo et al., 2015). Perhaps metalworkers followed different 588 production sequences, depending on whether they had immediate access to alloying materials. 589 Ingot sizes tend to vary, and there is little evidence for standardization. It is difficult to track the exact pathways of metal from smelting sites to casting foundries in settlements. However, there is certainly nothing comparable to the fortified Cypriot sites that some interpret as way stations

592 for copper travelling from the mines to the coast (Kassianidou, 2012: 97; Peltenburg, 1996: 35).

593 Metalworkers may have brought the raw metal from smelting sites to the more densely settled

594 areas themselves. The only evidence for the consolidation of metal resources comes from 595 examples of very large ingots, which are found in many museums in western Georgia (e.g.

596 Ozurgeti Museum, Dadiani Museum in Zugdidi, Kutaisi State Historical Museum). Their size in 597 relation to the crucibles found at smelting sites suggests that these ingots may be metal 598 consolidated from several different smelting episodes. One example in the Kutaisi State 599 Historical museum is only partially fused, and many different artifacts are visible. Since most of 600 these very large examples have no detailed contextual information, it is difficult to know whether 601 the metal was consolidated as part of a non-retrievable offering or as a means of amassing 602 metallic wealth.

603 The highly dispersed pattern of production found in smelting activities also extends to 604 secondary production - the process of making finished goods out of raw metal (figure 12). 605 Mikeladze notes "the presence of bronze casting molds at all Colchian settlements beginning at 606 least from the end of the 3rd millennium BC, despite their strictly agricultural character" 607 (Mikeladze, 1990: 26) (NES translation). Many of these settlements are in lowland coastal areas 608 somewhat removed from the foothill zones where smelting sites are concentrated. At Ispani, an 609 Early Bronze Age settlement found beneath peat deposits near the modern resort town of 610 Kobuleti, several tuyères and casting molds were found (Mikeladze and Khakhutaishvili, 1985 : $611 \mathrm{Pl} .4$ ). The settlement has been dated by radiocarbon to the 3rd millennium BC (Burchuladze et 612 al., 1976: 359; Burchuladze and Togonidze, 1987: 244). Other early evidence for casting and 613 shaping of artifacts comes from the central tell settlement at Pichori and Anaklia II, in layers 614 dated to the late 3rd and early 2nd millennia BC (Apakidze, 2009: 334, 337, Tf . 339-311; 
615 Baramidze et al., 2002; Mikeladze, 1990: Pl. 4). These include molds for hoes and axes, as well 616 as other implements.

617 Evidence for secondary metal production is equally abundant in later periods that are 618 contemporary with the Supsa-Gubazeuli smelting sites. The tell settlement of Namcheduri has a 619 stratigraphic sequence spanning the Late Bronze Age to the Classical period (Mikeladze and 620 Khakhutaishvili, 1985). Casting molds are found in many levels (VI, V, and III, dated by the 621 excavators to the mid-second millennium BC, the 12th-11th c. BC, and no later than the 7th c. $622 \mathrm{BC}$, respectively), and include those for making jewelry, miniature and full-size axes, and a 623 dagger or spear (Mikeladze and Khakhutaishvili, 1985: Pl. 36). Tuyères were found in 624 construction fill between Namcheduri levels III and IV, and were interpreted by the excavators 625 as originating from an earlier workshop at the base of the mound (Mikeladze and 626 Khakhutaishvili, 1985: 26-27). A broad range of metallurgical implements, including tuyères, 627 crucible fragments, ladles, and a wide variety of molds, were found at Choloki, another site in 628 the immediate vicinity (Apakidze, 2009: 340-341; Chavleishvili, 1991). Architectural remains at 629 Choloki are relatively well preserved, and show that metal production was carried out in a small 630 circular building with a single furnace. Namcheduri and Choloki were probably part of a mosaic 631 of patchy, low density settlement, located on drier ground within a marshy landscape (Connor et 632 al., 2007; Mikeladze and Khakhutaishvili, 1985: 4, P1 . 1; Tsetskhladze, 1999: 31-35). The 633 presence of metalworking debris in two places suggests that artifact production may not have 634 been restricted to a single area within this low density settled area.

635 Metal production debris has been found at numerous other LBA-EIA settlements in

636 Colchis. Recent excavations at Kulevi have yielded a casting crucible, tuyères, numerous axe and 637 jewelry molds (Papuashvili and Jibladze, 2014), as well as a bronze ingot and a possible iron 638 bloom (personal observation, Poti Museum of Colchian Culture), which the excavator dates to 639 the 8th-7th centuries BC (Papuashvili, personal communication). A dagger mold was found 640 along with "pre-antique" (roughly 8th-early 6th c. BC) ceramics at Pichori, Mound 4, another 641 smaller tell settlement 35-40 m from the Pichori settlement discussed above (Apakidze, 2009:

642 335). Crucibles, ingot fragments, and a possible furnace were discovered near the top of 643 Sukhumi Hill and dated to the turn of the 1st millennium BC on ceramic evidence (Kalandadze, 644 1953: 89-91). The description of the finds and the accompanying drawings suggest the 645 possibility that this furnace was intended for melting copper to produce large ingots 
646 (Kalandadze, 1953: figs. 28-30, Pls. II, XXII). At Dablagomi near Vani, molds, crucibles, and 647 copper-alloy ingots were found (Tolordava, 1977). Farther inland, crucible fragments have been

648 found near Itkhvisi, a site with occupation spanning the 1st millennium BC (Apakidze, 2009:

649 354, Tf. 395). A mold for inlay was discovered in excavations at Tskheta and dated to the 8th-5th 650 c. BC (Sulava, 2008).

651 Assessing the social contexts of craftspeople who made bronze artifacts is challenging,

652 since detailed contextual information is often lacking, and the predominantly wooden

653 architecture of the period typically does not preserve well. The pyrotechnological feature on top

654 of Sukhumi Hill may be significant, since bringing fuel and metal up to the top of a steep hill 655 seems unnecessary in the absence of an explicit desire to control and/or protect the products of 656 metal production. Whatever this decision signifies about the control of this particular workshop, 657 the ubiquity of secondary production debris at a wide range of sites suggests that, as a whole, 658 copper and bronze production was not controlled, even if bronze was a valued material used for a 659 range of prestige and agricultural items. The lack of centralization, coupled with a general lack 660 of evidence for extreme hierarchy until well into the 1st millennium BC (see Kacharava and 661 Kvirkvelia, 2009), shows that local elites probably did not exercise exclusive control over the 662 production of artifacts from raw metal. Coupled with the ubiquity of ore deposits and the 663 dispersed distribution of smelting sites, the evidence of secondary production suggests that 664 efforts at direct control over production of raw copper and most types of artifacts were bound to 665 be futile.

\section{Conclusion: The Social Organization of Bronze Production}

Detailed examination of the production of copper alloys, from mining and smelting in the

671 an industry whose defining feature at nearly every stage is dispersion. Mining was carried out on 672 a small scale at numerous different outcrops, as evidenced by the chemical analysis of a large 673 sample of slags. Smelting was equally dispersed, and any putative attempt at coordination would 674 have had to confront serious challenges posed by the rough topography and dense vegetation of 675 the sub-tropical landscape. Casting and forging of artifacts did not take place at the smelting 676 sites, but the distribution of secondary production debris shows a similar lack of spatial 
concentration. Molds, tuyères and casting crucibles are found at numerous sites, but never in

678 quantities that suggest massive centralized production. There are some ambiguous hints (e.g. the

679 hilltop workshop at Sukhumi) that metal resources were deemed worthy of protection, and the

680 ubiquity of Late Bronze Age hoards suggests some accumulation of metal wealth, but there is no

681 evidence that control of production was in any way exclusive. This situation contrasts with shell

682 bead production in the Channel Islands (Arnold and Munns, 1994). In the latter case, elites

683 maintained exclusive control over a key node in the production and distribution chain, giving

684 them effective control over bead production, even if it did not take place under their direct

685 supervision. In ancient Colchis, the ubiquitous evidence for both primary and secondary

686 production, the modest quantities of metallurgical debris found at any individual site, and the

687 broad range of metal uses all point to a single conclusion: exclusive control of the metal supply

688 was impossible.

689 Many lines of evidence, though indirect, point to seasonal smelting carried out by

690 metalworkers moving between lowland areas and foothill/mountain zones. First, climatic factors

691 would have made it difficult to carry out smelting year-round. Some areas of western Georgia

692 receive more than $2500 \mathrm{~mm}$ of precipitation per year, with significant seasonal variation (Connor

693 et al., 2007: 32-33; Lydolph, 1985: 280). Snow would have prevented access to mines at higher

694 elevations in the winter. If the metalworkers also engaged in agriculture, smelting would have to

695 have been scheduled around the harvest and planting seasons. Second, there is little evidence of

696 permanent habitation at smelting sites in the Supsa-Gubazeuli region, given the almost

697 exclusively metallurgical character of the finds. With few possible exceptions (Khakhutaishvili,

6982009 [1987]: 95), settlement sites have not been found in the vicinity of smelting sites. This may

699 reflect a real absence of habitation in these areas, or it may reflect the difficulty of finding

700 settlements in such a densely vegetated landscape. Third, intra-site chemical variation (see

701 discussion of Site 43 above) and the small size of the sites are consistent with intermittent

702 smelting episodes in which different ore outcrops were exploited at different times.

703 Based on the current evidence, it is not possible to say whether metalworkers lived

704 permanently within a few kilometers of their smelting camps and travelled back and forth every

705 day, or whether they lived tens of kilometers away in the more densely settled coastal lowland

706 areas and stayed at the smelting sites only for the duration of a seasonal smelting campaign.

707 Whether or not the metalworkers themselves moved between these different topographic zones, 
the evidence clearly demonstrates the regularized movement of people and materials between

709 these areas. Considering the output of each smelting site and the modest distances involved,

710 however, the balance of evidence favors a model where people producing metal were also

711 involved with its transport to more populated areas. The smelting sites, therefore, served as

712 intermediate nodes between the areas where coastal/lowland raw materials, labor, and markets

713 were located and the ore-bearing zones located somewhat further up in the mountains.

714 In this light, the spatial segmentation of different stages of production should not be seen

715 as evidence for horizontally specialized production. In other words, spatial segmentation of

716 production does not require social segmentation of metalworkers by production stage.

717 Metalworkers probably moved between lowland and foothill areas as part of a regular pattern of

718 movement. If different people were involved in secondary production, primary smelting, and ore

719 mining, it is likely that these groups would have been closely connected socially, probably by

720 kinship relations. The ubiquity of small-scale production debris suggests that metallurgical

721 knowledge was fairly widespread in Colchian society. Yet at the same time, the complex, multi-

722 stage process of copper-sulfide smelting would have required significant time to learn, and a

723 relatively structured system of apprenticeship probably existed.

724 There is much discussion in the literature about the formation of a specialized group of

725 craftspeople, especially in the 1st half of the 1st millennium BC (Khakhutaishvili, 1981;

726 Khakhutaishvili, 2009 [1987]: 123-125; Khakhutaishvili, 2008; Khakhutaishvili and Khalvashi,

727 2010). Given the considerable elasticity of the term "specialization" (Clark and Parry, 1990;

728 Costin, 1991; Flad and Hruby, 2007; Muller, 1984), it is worth examining how it has been

729 applied in the Colchian case. Significant emphasis has been placed on textual descriptions in

730 Appolonius of Rhodes' Argonautica, linking these accounts to ethnographic descriptions of

731 metalworkers in Georgia (Khakhutaishvili, 2009 [1987]: 125). Passages in the Argonautica seem

732 to present a textbook case of specialization defined as an activity undertaken at the expense of

733 subsistence pursuits: "[The Chalybes] do not use the ploughing ox. They not only grow no corn,

734 but plant no vines or trees for their delicious fruit and graze no flocks in dewy pastures. Their

735 task is to dig for iron in the stubborn ground and they live by selling the metal they produce. To

736 them no morning ever brings a holiday. In a black atmosphere of soot and smoke they live a life

737 of unremitting toil." (Argonautica 2.1002-1008, tr. E.V. Rieu). 
Interpretations of this vivid passage, composed sometime in the $3^{\text {rd }}$ century BC (Murray, 2014), must be undertaken with caution. The fact that the passage refers to iron production makes its relevance to the organization of copper smelting as much as 1000 years earlier somewhat questionable. Though the accuracy of external descriptions of peoples and places is

742 itself uncertain, the Chalybes and the Colchians are distinguished in the narrative, with the land 743 of the Chalybes situated somewhere to the south and west of Colchis (Tsetskhladze, 1995: 321;

744 Tsetskhladze and Treister, 1995: 18). Conservatively, one may conclude that late 1st millennium

745 BC descriptions of metal producers in the southeastern Black Sea region simply reflect the long746 standing tradition of metallurgical expertise in the region. Earlier archaeologists studying these 747 metallurgical landscapes have not simply taken the reports of extreme specialization (i.e. the 748 complete abandonment of agriculture in favor of metal production) at face value. Rather, they 749 present a picture of seasonal metal production mostly in line with the new data presented here 750 (Khakhutaishvili, 2009 [1987]: 123-125), with the exception that earlier hypotheses of centralized administration are no longer tenable.

This detailed examination of the copper and bronze industry in western Georgia provides

753 no evidence that metal production was organized and controlled by a single unified authority.

754 Yet metalworkers at these sites constructed workshops with similar layouts, built similar 755 furnaces, and used similar smelting techniques. If these similarities were not the product of 756 imposed top-down organization, they nonetheless require explanation in the context of the 757 proposed model of dispersed mining and smelting carried out by independent groups of 758 metalworkers.

759 Evidence of homogeneity in technological practice does not necessarily indicate the 760 existence of a centralized, highly organized, tightly controlled mode of production. A better way 761 of explaining these shared characteristics is through reference to the concept of a "community of 762 practice" (Stöllner et al., 2016; Wenger, 1998, 2000). This term refers to a group of craftspeople 763 who interact and exchange ideas in both structured and unstructured ways. "Communities of 764 practice" include both tightly connected, constantly interacting groups and more loosely joined 765 associations (Wenger and Snyder, 2000: 139-140). As a whole, the metalworkers on the 766 southeastern coast of the Black Sea probably fall on the more loosely connected end of that 767 spectrum, though smaller, kin-related sub-groups within this larger community likely had more 768 regularized contact. Dispersed groups and irregular contact are by no means insurmountable 
barriers to community formation, nor is the fact that metal producers were engaged in independent mining enterprises. Ethnographic and historic studies of mining and craft production

771 have shown that metalworkers maintain social ties over long distances, even in spite of high

772 levels of mobility and transience (Douglass, 1998). Ideas and techniques developed by some 773 members of the group may be transferred to others through apprenticeships or less structured 774 modes of communication (Minar and Crown, 2001; Wendrich, 2013). Regular movements of 775 people and materials between centers of settlement and marginal foothill zones would facilitate 776 these contacts, as areas rich in metal deposits drew in craftspeople living in different lowland 777 areas. These kinds of social relations create a defining feature of communities of practice: their 778 "shared repertoire" for approaching and solving particular problems (Wenger, 2000: 229). This 779 concept not only explains why, with minor variations, copper smelting sites are remarkably 780 similar, it also explains how this homogeneity can occur without accompanying evidence for top781 down organization.

782 This reconstruction of the organization of Colchian metal contrasts sharply with other 783 well-documented contemporary metal production systems in Southwest Asia (Ben-Yosef et al., 784 2012; Levy et al., 2014; Weisgerber, 2003: 85-86). Despite the recognition that craft production 785 indices are theoretically independent, many of the better documented case studies show strong 786 correlations between scale, concentration, and organizational complexity. The smelting 787 landscapes of the southeastern Black Sea region provide a clear counterexample. In aggregate, 788 the copper production industry was large-scale, as evidenced by the quantity of both metal 789 artifacts and production debris found in the region. Yet individually, sites are quite small, and 790 many lines of evidence point to an industry composed of numerous small groups of 791 metalworkers who, though they employed similar technologies and probably had at least 792 intermittent contact with one another, did not coordinate activities in any systematic way. While 793 the Colchian case is remarkable for the number of sites recovered in such a small area, this 794 model of production was probably not unique to the South Caucasus. The Colchian smelting 795 landscape has some intriguing parallels in Central Europe (Stöllner, 2003: 433-435; Stöllner et 796 al., 2016), and if more small smelting sites like Politiko Phorades (Knapp and Kassianidou, 797 2008) are found, the organization of LBA Cypriot mining and smelting may require re798 evaluation. 
The Colchian copper mining and smelting landscape might be compared to a slow-

800 motion gold rush. The rates of production surely did not approach those of the Californian or

801 Yukon gold rushes; Colchian production landscapes formed over several hundred years. There is

802 no evidence that Colchian mining operations followed the claim systems of the western gold

803 rushes, but as with the Toro of Uganda (Childs, 1998), there were probably local norms and

804 practices governing mining rights. The pattern of numerous small groups of miners, smelters,

805 and craftspeople exploiting metal deposits in an uncoordinated manner applies to both situations.

806 The model of loose networks of mining communities in the American West (Douglass, 1998),

807 involving exchange of ideas, competitive behaviors, and fairly high levels of mobility, is

808 applicable to the Colchian copper industry. Fundamentally, these cases show how production

809 taking place at individually small-scale sites can, in aggregate, play a major role in shaping the

810 landscape.

811 This discussion of the Colchian copper industry adds a new dimension to recent

812 discussions of technological development and social organization of craft production. Recent

813 work on the emergence of metallurgy on the Iranian plateau has argued that technological

814 developments do not always follow a predictable linear sequence according to the so-called

815 "Levantine Paradigm" (Thornton, 2009a, 2009b). Thornton demonstrates the co-existence of

816 production in both domestic spaces and specialized workshop areas at the same site (Thornton,

817 2009a: 189-198). Similar evidence has emerged even in the Southern Levant. Copper smelting

818 debris in Timna, originally assigned to the Chalcolithic due to its simpler technology, has been

819 re-dated on the basis of paleomagnetic intensity measurements to the Early Iron Age, roughly

820 contemporary with the large fortified smelting camp at Site 30 (Ben-Yosef et al., 2010). Copper

821 production landscapes in the South Caucasus are remarkable for their combination of small site

822 sizes, dispersed distribution, and large aggregate scale of production. The Colchian metal

823 production industry shows that large industries with high aggregate output using complex

824 technologies need not be centralized, nor must they be coordinated on a large scale.

\section{Acknowledgements}

This article is based on a dissertation chapter by Nathaniel Erb-Satullo. Committee 
830 and provided helpful feedback on issues to consider. Amiran Kakhidze (Batumi Archaeological 831 Museum) was influential in supporting our field project. The field team included Marc Cox, 832 Amy Lawn, Anthony Gilmour and Emzar Kakhidze. Bruce Kaiser provided guidance on the use 833 of the pXRF and area-under-the-curve calculations. Special thanks to Shadreck Chirikure for 834 assistance in submitting slag samples for powder WDS-XRF analysis at the University of 835 Capetown, and to two anonymous reviewers for their comments. An NSF Doctoral Dissertation 836 Improvement Grant (BCS-1338893), and an NSF Graduate Research Fellowship (DGE0644491 837 and DGE1144152) to Nathaniel Erb-Satullo provided funding for this research. Additional 838 support came from the British Academy (SG100285), the National Geographic Society 839 (GEFNE30-11) the Davis Center for Russian and Eurasian Studies at Harvard University, the 840 Jens Aubrey Westengard Fund, and the Harvard Anthropology Department. Digital elevation 841 data in maps was provided by SRTM and ASTER (a product of METI and NASA). 


\section{Figure Captions}

845 Figure 1. Map of Late Bronze-Early Iron Age copper smelting sites in Western Georgia, mapped

846 by the authors in 2010-2014. Contours in the largest-scale map are at $5 \mathrm{~m}$ intervals.

848 Figure 2. Lines of sight between smelting sites in the Supsa-Gubazeuli area, assuming a $2 \mathrm{~m}$

849 target and observer height. Contours are at $5 \mathrm{~m}$ intervals.

851 Figure 3. Geological map with approximate locations of known copper deposits. Information on

852 base geology from Nazarov (1966). Each circle indicates approximate location of a deposit

853 mentioned in Gabunia (1933: 556-557). Information about exact locations is variable, hence the

854 variable sizes of the circles. Contours are at $100 \mathrm{~m}$ intervals.

856 Figure 4. Schematic representation of how paragenetic mineral variation in ore veins is translated

857 into the chemical composition of the slag. The example shown is for zinc-bearing minerals such

858 as sphalerite. Similar processes may also apply to other elements, though partitioning and

859 volatilization may affect how well these variations translate from ore to slag.

861 Figure 5. Plot of molybdenum versus cobalt trace element content in copper smelting slags, as 862 measured by powder WDS-XRF.

864 Figure 6. Alternative models of copper ore mining and distribution to smelting sites.

866 Figure 7. Intra-site variation in slag composition as determined by pXRF. Each bar represents a

867 single context. Site numbers are given before the “-”. Surface collections (-S) are treated as a

868 single context. Broken vertical lines divide contexts from different sites.

870 Figure 8. Map of the presence of $\mathrm{Zn}$ at smelting sites in the Supsa-Gubazeuli production area. Pie 871 charts show the proportion of samples at each size which have no $\mathrm{Zn}$, low $\mathrm{Zn}$, and high $\mathrm{Zn}$. The 872 size of the pie chart is related to the number of samples analyzed (see figure A1 in online 873 supplementary material). Pie charts are labeled with site numbers. 
875 Figure 9. Map of the presence of Mo at smelting sites in the Supsa-Gubazeuli production area.

876 Pie charts show the proportion of samples at each size which have no Mo, low Mo, and high Mo.

877 The size of the pie chart is related to the number of samples analyzed (see figure A1 in online

878 supplementary material). Pie charts are labeled with site numbers.

880 Figure 10. Map of the combined presence of $\mathrm{Zn}$ and Mo at smelting sites in the Supsa-Gubazeuli 881 production area. The size of the pie chart is related to the number of samples analyzed (see figure 882 A1 in online supplementary material). Pie charts are labeled with site numbers.

884 Figure 11. Model showing independent groups of metalworkers exploiting multiple ore deposits 885 in a zoned ore body.

887 Figure 12. Map of sites in western Georgia where evidence of secondary production 888 (casting/melting crucibles, tuyères, casting molds) has been found. 


\begin{tabular}{|c|c|c|c|c|c|c|c|}
\hline $\begin{array}{l}\text { Site } \\
\text { Number }\end{array}$ & $\begin{array}{l}\text { Khakhutaishvili } \\
\text { Site Name }\end{array}$ & $\begin{array}{l}\text { Collected } \\
\text { Slag Pile } \\
\text { (Cubic } \\
\text { Meters) }\end{array}$ & $\begin{array}{l}\text { Slag (kg) } \\
\text { (Calculation 1) }\end{array}$ & Area $\left(\mathrm{m}^{2}\right)$ & $\begin{array}{l}\text { Thickness } \\
(\mathrm{m})\end{array}$ & $\begin{array}{l}\text { Slag }(\mathrm{kg}) \\
\text { (Calculation } \\
\text { 2) }\end{array}$ & Notes \\
\hline 8 & Askana II,1 & 8 & 12000 & 80 & 1 & 13000 & \\
\hline 8 & Askana II, 2 & 10 & 15000 & 100 & 1.2 & 19000 & \\
\hline 15 & Askana III,1 & 8 & 12000 & 600 & 0.4 & 38000 & \\
\hline 18 & Mziani I & 10 & 15000 & 300 & $\mathrm{n} / \mathrm{a}$ & $\mathrm{n} / \mathrm{a}$ & $\begin{array}{l}\text { Slag heap } \\
\text { damaged by } \\
\text { agricultural } \\
\text { activities }\end{array}$ \\
\hline 19 & Mziani II & 4 & 6000 & $\mathrm{n} / \mathrm{a}$ & $\mathrm{n} / \mathrm{a}$ & $\mathrm{n} / \mathrm{a}$ & \\
\hline 20 & Mziani III,1 & 4 & 6000 & 200 & 0.3 & 9000 & $\begin{array}{l}\text { Slag heaps } \\
\text { associated } \\
\text { with other } \\
\text { furnaces at } \\
\text { Mziani III } \\
\text { too heavily } \\
\text { disturbed }\end{array}$ \\
\hline 21 & Mziani IV & 2 & 3000 & 100 & $\mathrm{n} / \mathrm{a}$ & $\mathrm{n} / \mathrm{a}$ & $\begin{array}{l}\text { Slag heap } \\
\text { partially } \\
\text { damaged. }\end{array}$ \\
\hline 14 & Mshvidobauri I & $\mathrm{n} / \mathrm{a}$ & $\mathrm{n} / \mathrm{a}$ & 400 & 0.4 & 25000 & \\
\hline - & $\begin{array}{l}\text { Mshvidobauri } \\
\text { IV }\end{array}$ & 10 & 15000 & 400 & $\mathrm{n} / \mathrm{a}$ & $\mathrm{n} / \mathrm{a}$ & $\begin{array}{l}\text { Slag heap } \\
\text { partially } \\
\text { damaged. }\end{array}$ \\
\hline 16 & Nagomari I,1 & 5 & 8000 & 200 & 0.25 & 8000 & \\
\hline - & Charnali I,1 & 6 & 9000 & 60 & 1 & 9000 & $\begin{array}{l}\text { Two slag } \\
\text { heaps of } \\
\text { Charnali I } \\
\text { are reported } \\
\text { as } \\
\text { overlapping }\end{array}$ \\
\hline - & Charnali I,2 & 3 & 5000 & & $\mathrm{n} / \mathrm{a}$ & $\mathrm{n} / \mathrm{a}$ & $\begin{array}{l}\text { Two slag } \\
\text { heaps of } \\
\text { Charnali I } \\
\text { are reported } \\
\text { as } \\
\text { overlapping }\end{array}$ \\
\hline - & Jikhanjuri I,1 & 4 & 6000 & 30 & 0.55 & 3000 & $\begin{array}{l}\text { Text } \\
\text { mentions } 4 \\
\text { cubic meter } \\
\text { in one place } \\
\text { and } 5 \text { in } \\
\text { another. }\end{array}$ \\
\hline- & Jikhanjuri I,2 & 4 & 6000 & 20 & 0.35 & 1000 & \\
\hline- & Jikhanjuri I,3 & 5 & 8000 & 40 & 0.4 & 3000 & \\
\hline- & Jikhanjuri III & 5 & 8000 & 40 & 0.35 & 2000 & \\
\hline- & Jikhanjuri IV & 10 & 15000 & 60 & 0.4 & 4000 & \\
\hline 55 & Tsetskhlauri I & 10 & 15000 & 600 & 0.5 & 47000 & \\
\hline
\end{tabular}




\begin{tabular}{|l|l|r|r|r|r|r|r|}
\hline $\begin{array}{l}\text { possibly } \\
56\end{array}$ & Tsetskhlauri II & 10 & 15000 & 300 & 0.45 & 21000 & \\
\hline- & Tsetskhauri III & 6 & 9000 & 200 & 0.4 & 13000 & \\
\hline 54 & Leghva I, 1 & 5 & 8000 & 100 & 0.5 & 8000 & \\
\hline 54 & Leghva I, & 6 & 9000 & n/a & n/a & n/a & \\
\hline 74 & Chogha I & 5 & 8000 & n/a & n/a & n/a & \\
\hline
\end{tabular}

894 Table 1. Rough calculations of slag at previously excavated sites, using two independent

895 methods. Calculation 1 uses the cubic meters of slag reported in Khakhutaishvili (2009 [1987]),

896 and density estimated by Gilmour in the foreword to that book. Calculation 2 takes

897 Khakhutaishvili's report of the area and depth of the slag heap, and approximates the volume of

898 the slag heap (dirt included), modeling it as a generalized cone. Estimated measurements of slag

899 mass per cubic meter of (unexcavated) slag heap (from testing of Site 43 in 2012) were then used

900 to estimate the total slag mass. All estimates were rounded to the nearest $1000 \mathrm{~kg}$. Note:

901 Khakhutaishvili often subdivided sites, using with Arabic numerals following the Roman

902 numerals to refer to different furnaces and their associated slag heap. Those slag heaps with

903 Arabic numerals are therefore only part of the total quantity of slag at a site. For example, while

904 dimensions of the slag heap and quantities of slag are reported for Mziani III,1, no values are

905 given for Mziani III,2 and Mziani III,3.

906 
Abesadze, T., Bakhtadze, R., 2011 [1988]. Kolkhuri kulturis metalurgiis istoriisatvis (On the history of the metallurgy of the Colchis Culture) (in Georgian with Russian summary). Georgian National Museum, Tbilisi.

Apakidze, J., 2009. Die Spätbronze- und Früheisenzeit in West- und Zentralkaukasien: Chronologische Studien zur Kolchis-Kultur. Marie Leidorf GMBH, Rahden, Germany.

Apollonius of Rhodes, [1971]. The Argonautica. Translated by Reiu, E.V. Penguin, London.

Arnold, J.E., Munns, A., 1994. Independent or attached specialization: the organization of shell bead production in California. Journal of Field Archaeology 21, 473-489.

Bachmann, H.G., Rothenberg, B., 1980. Die Verhüttungsverfahren von Site 30, in: Conrad, H.G. (Ed.), Antikes Kupfer im Timna-Tal. Deutsches Bergbau-Museum, Bochum, Germany, pp. 215236.

Baramidze, M.B., Jibladze, L., Dzidziguri, L., 2002. Predmety, svyazannye c metallurgicheskim proizvodstvom iz severo-zapadnoy Kolkhidy. Kavkazovedenie 1, 41-43.

Bell, C., 2012. The merchants of Ugarit: oligarchs of the Late Bronze Age trade in metals, in: Kassianidou, V., Papasavvas, G. (Eds.), Eastern Mediterranean metallurgy and metalwork in the second millennium BC. Oxbow Books, Oxford, pp. 180-187.

Ben-Yosef, E., 2010. Technology and Social Process: Oscillations in Iron Age Copper Production and Power in Southern Jordan, Department of Anthropology. University of California, San Diego, San Diego, CA.

Ben-Yosef, E., Shaar, R., Tauxe, L., Ron, H., 2012. A new chronological framework for Iron Age copper production at Timna (Israel). Bulletin of the American Schools of Oriental Research 367, 31-71.

Ben-Yosef, E., Tauxe, L., Levy, T.E., 2010. Archaeomagnetic dating of copper smelting site F2 in the Timna Valley (Israel) and its implications for the modelling of ancient technological developments. Archaeometry 52, 1110-1121.

Bray, P., Cuénod, A., Gosden, C., Hommel, P., Liu, R., Pollard, A.M., 2015. Form and flow: the 'karmic cycle' of copper. Journal of Archaeological Science 56, 202-209.

Bray, P., Pollard, A.M., 2012. A new interpretive approach to the chemistry of copper-alloy objects: source, recycling and technology. Antiquity 86, 853-867.

Burchuladze, A.A., Gedevanishvili, L.D., Togonidze, G.I., 1976. Tbilisi radiocarbon dates III. Radiocarbon 18, 355-361. 
Burchuladze, A.A., Togonidze, G.I., 1987. Tbilisi radiocarbon dates IV. Radiocarbon 29, 239262.

Campbell, R.B., Li, Z., He, Y., Jing, Y., 2011. Consumption, exchange and production at the Great Settlement Shang: bone-working at Tiesanlu, Anyang. Antiquity 85, 1279-1297.

Chartolani, S., 1989. K istorii nagor'ya zapadnoy Gruzii doklassovoy epoxi (On the history of the highlands of western Georgia during the pre-class era). Metsniereba, Tbilisi.

Chartolani, S., 2001. Alter Bergbau in Swanetien, in: Gambaschidze, I., Hauptmann, A., Slotta, R., Yalçin, Ü. (Eds.), Georgien: Schätze aus dem land des goldenen Vlies. Deutsches BergbauMuseum, Bochum, pp. 120-129.

Chavleishvili, I., 1991. Kolkhuri brinjaos satsarmoo kera cholok-ochkhamuris khertvisshi (A Colchian bronzecasting production hearth from the Choloki-Ochkhamuri interfluve) (in Georgian with Russian summary). Samkhret-Dasavlet Sakartvelos Dzeblebi (Monuments of Southwestern Georgia) XIX, 3-26.

Chernykh, E.N., 1992. Ancient metallurgy in the USSR: the early metal age. Cambridge University Press, Cambridge.

Childs, S.T., 1998. 'Find the ekijunjumira' Iron mine discovery, ownership, and power among the Toro of Uganda, in: Knapp, A.B., Pigott, V.C., Herbert, E.W. (Eds.), Social approaches to an industrial past: The archaeology and anthropology of mining. Routledge, London, pp. 123-137.

Clark, J.E., Parry, W.J., 1990. Craft specialization and cultural complexity. Research in Economic Anthropology 12, 289-346.

Connor, S.E., Thomas, I., Kvavadze, E.V., 2007. A 5600-yr history of changing vegetation, sea levels and human impacts from the Black Sea coast of Georgia. Holocene 17, 25-36.

Constantinou, G., 1982. Geological features and ancient exploitation of the cupriferous sulphide orebodies of Cyprus, in: Muhly, J.D., Maddin, R., Karageorghis, V. (Eds.), Acta of the International Archaeological Symposium on Early Metallurgy in Cyprus, 4,000-500 BC, Larnaca, Cyprus 1-6 June 1981. Pierides Foundation, Nicosia, pp. 13-24.

Costin, C.L., 1991. Craft specialization: issues in defining, documenting, and explaining the organization of production, in: Schiffer, M.B. (Ed.), Archaeological method and theory. University of Arizona Press, Tucson, pp. 1-56.

Costin, C.L., 1996. Craft production and mobilization strategies, in: Wailes, B. (Ed.), Craft specialization and social evolution: in memory of V. Gordon Childe. University Museum of Archaeology and Anthropology, Philadelphia, pp. 211-225. 
997

Costin, C.L., 2011. Textiles and Chimú identity under Inka hegemony on the north coast of Peru, in: Little, W.E., McAnany, P.A. (Eds.), Textile economies: power and value from the local to the transnational. Altamira, Lanham, MD, pp. 101-124.

Courtois, 1982. L'activité métallurgique et les bronzes d'Enkomi au Bronze Récent (1650-1100 avant J.-C.), in: Muhly, J.D., Maddin, R., Karageorghis, V. (Eds.), Acta of the International Archaeological Symposium on Early Metallurgy in Cyprus, 4,000-500 BC, Larnaca, Cyprus 1-6 June 1981. Pierides Foundation, Nicosia, pp. 155-174.

Douglass, W.A., 1998. The mining camp as community, in: Knapp, A.B., Pigott, V.C., Herbert, E.W. (Eds.), Social approaches to an industrial past: The archaeology and anthropology of mining. Routledge, London, pp. 97-108.

Earle, T., 1981. Comment on P. Rice, Evolution of specialized pottery production: a trial model. Current Anthropology 22, 230-231.

Erb-Satullo, N.L., Gilmour, B.J.J., Khakhutaishvili, N., 2014. Late Bronze Age and Early Iron Age copper smelting technologies in the South Caucasus: The view from ancient Colchis c. 1500-600 BC. Journal of Archaeological Science 49, 147-159.

Erb-Satullo, N.L., Gilmour, B.J.J., Khakhutaishvili, N., 2015. Crucible technologies in the Late Bronze-Early Iron Age South Caucasus: Copper processing, tin bronze production, and the possibility of local tin ores Journal of Archaeological Science 61, 260-276.

Erb-Satullo, N.L., Gilmour, B.J.J., Khakhutaishvili, N., submitted. The Ebb and Flow of Copper and Iron Smelting in the South Caucasus. Submitted to the journal Radiocarbon.

Flad, R., Hruby, Z., 2007. "Specialized" production in archaeological contexts: Rethinking specialization, the social value of products, and the practice of production. Archaeological Papers of the American Anthropological Association 17, 1-19.

Gabunia, K., 1933. Med' (Copper), in: Godabrelidze, S.A. (Ed.), Mineral'nye resursy SSR Gruzii (Mineral resources of the Soviet Socialist Republic of Georgia) Gostekhizdat Gruzii "Tekhnika da Shroma", Tiflis, pp. 477-561.

Gale, N.H., 1999. Lead isotope characterization of the ore deposits of Cyprus and Sardinia and its application to the discovery of the sources of copper for Late Bronze Age oxhide ingots, in: Young, S.M.M., Pollard, A.M., Budd, P., Ixer, R.A. (Eds.), Metals in Antiquity. Archaeopress, Oxford

Gale, N.H., Stos-Gale, Z.A., 1982. Bronze Age Copper Sources in the Mediterranean: a new Approach. Science 216, 11-19.

Ghambashidze, D., 1919. Mineral resources of Georgia and Caucasia: Manganese industry of Georgia. George Allen and Unwin, London. 
1043 Gilmour, B.J.J., 2009. Forward 1, in: Khakhutaishvili, D.A. (Ed.), The manufacture of iron in 1044 ancient Colchis. Archaeopress, Oxford.

1045

1046

1047

1048

1049

1050

1051

1052

1053

1054

1055

1056

1057

1058

1059

1060

1061

1062

1063

1064

1065

1066

1067

1068

1069

1070

1071

1072

1073

1074

1075

1076

1077

1078

1079

1080

1081

1082

1083

1084

1085

1086

1087

1088
Gugushvili, V., Popkhadze, N., Beridze, T., Khutsishvili, S., 2010. Sources of base, precious and rare metals during the Tethyan Phanerozoic evolution of the Caucasus and Pontides, Proceedings of the XIX CBGA Congress. School of Geology, Aristotle University of Thessaloniki, Thessaloniki, Greece, pp. 333-341.

Gzelishvili, I.A., 1964. Zhelezoplavil'noe Proizvodstvo v Drevney Gruzii (Iron Smelting Production in Ancient Georgia). Metsniereba, Tbilisi.

Hardesty, D.L., 2010. Mining archaeology in the American West. University of Nebraska Press, Lincoln, NE.

Hauptmann, A., 2007. The archaeometallurgy of copper: evidence from Faynan, Jordan. Springer, Berlin.

Iessen, A.A., Degen-Kovalevskiy, B.E., 1935. Iz istorii drevney metallurgii Kavkaza. Gosudarstvennaya Akademiya Istorii Material'noy Kul'tury imeni N. Ya. Marra, Leningrad.

Janelidze, Z., 2007. Absolute age of the relief of the Black Sea coast zone of Georgia based on archaeological materials. Bulletin of the Georgian National Academy of Sciences 175, 74-76.

Janelidze, Z., Tatashidze, Z., 2010. Paleogeographical interpretation of archaeologic sites of the swamps of the Black Sea coast of Georgia. Bulletin of the Georgian National Academy of Sciences 4, 159-161.

Kacharava, D.D., Kvirkvelia, G.T., 2009. Recent archaeological finds on the upper terrace of the Vani site. Ancient Civilizations from Scythia to Siberia 14, 237-315.

Kalandadze, A., 1953. Sukhumis mtis arkeologiuri dzeglebi (Archaeological monuments of Sukumi Hill) (in Georgian with Russian summary). Apkhazetis Sakhelbani, Sukhumi.

Kassianidou, V., 2012. Metallurgy and metalwork in Enkomi: the early phases, in: Kassianidou, V., Papasavvas, G. (Eds.), Eastern Mediterranean Metallurgy and Metalwork in the Second Millennium BC. Oxbow Books, Oxford, pp. 94-106.

Kassianidou, V., 2013. Mining landscapes of prehistoric Cyprus. Metalla 20, 36-45.

Khakhutaishvili, D.A., 1976. A contribution of the Kartvelian tribes to the mastery of metallurgy in the ancient Near East, in: Harmatta, J., Komoróczy, G. (Eds.), Wirtschaft und Gesellschaft in Vorderasien. Akadémai Kiadó, Budapest, pp. 337-348.

Khakhutaishvili, D.A., 1977. K khronologii kolkhidsko-khalibskogo tsentra drevnezheleznoy metallurgii (On the chronology of the Colchian-Khalibian early iron metallurgy). Voprosy drevney istorii (Kavkazsko-blizhnevostochny sbornik) 5, 119-141. 
Khakhutaishvili, D.A., 1981. Yugo-zapadnaya Gruzia v VIII-VI vv. do n. e. (Southwestern Georgia in the 8th-6th centuries BC), in: Lordkipanidze, O.D. (Ed.), Demograficheskaya situatsiya v Prichyophomor'ye (Kolkhida) v period velikoy grecheskoy kolonizatsii (The demographic situation on the Black Sea Coast in the period of the great Greek colonization). Metsniereba, Tbilisi, pp. 329-333.

Khakhutaishvili, D.A., 2009 [1987]. The Manufacture of Iron in Ancient Colchis. Archaeopress,

Khakhutaishvili, N., 2008. Sotsialnaya i politicheskaya obstanovka primor'ya yugo-zapadhoy Georgia in the early Iron Age), Innovatsionnye aspecty issledovaniya kultury, arkheologii, etnologii, lingvistiki stran Chyornomorskogo basseyna (Innovative aspects of the research of the culture, archaeology, ethnology and linguistics of the countries of the Black Sea basin). Shota Rustaveli State University, Tbilisi, pp. 182-196. Bronse Age Cultures, Tire.

Killick, D., 2015. Archaeometallurgy as archaeology: a key-note lecture, in: Hauptmann, A., Modaressi-Tehrani, D. (Eds.), Archaeometallurgy in Europe III: Proceedings of the 3rd international conference, Deutsches Bergbau-Museum Bochum, June 29-July 1, 2011. Deutsches Bergbau-Museum, Bochum, Germany, pp. 295-300.

Kling, B., Muhly, J.D., 2007. Joan du Plat Taylor's Excavations at the Late Bronze Age Mining Settlement at Apliki Karamallos, Cyprus. Paul Åströms förlag, Sävdalen, Sweden.

Knapp, A.B., 2012. Metallurgical production and trade on Bronze Age Cyprus: Views and variations, in: Kassianidou, V., Papasavvas, G. (Eds.), Eastern Mediterranean Metallurgy and Metalwork in the Second Millennium BC. Oxbow Books, Oxford, pp. 14-25.

Knapp, A.B., Kassianidou, V., 2008. The archaeology of Late Bronze Age copper production: Politiko Phorades on Cyprus, in: Yalçin, Ü. (Ed.), Anatolian Metal IV. Bochum Vereinigung der Freunde von Kunst und Kultur im Bergbau, Bochum, Germany, pp. 135-147.

Levy, T.E., 2009. Pastoral nomads and Iron Age metal production in ancient Edom, in:

Szuchman, J. (Ed.), Nomads, tribes, and the state in the ancient Near East. Oriental Instiute, Chicago, pp. 147-177.

Levy, T.E., Adams, R.B., Najjar, M., Hauptmann, A., Anderson, J.D., Brandl, B., Robinson, M.A., Higham, T., 2004. Reassessing the chronology of Biblical Edom: new excavations and C14 dates from Khirbat en-Nahas (Jordan). Antiquity 78, 865-879. 
1134 Levy, T.E., Ben-Yosef, E., Najjar, M., 2012. New perspectives on Iron Age copper production and society in the Faynan Region, Jordan, in: Kassianidou, V., Papasavvas, G. (Eds.), Eastern Mediterranean Metallurgy and Metalwork in the Second Millennium BC. Oxbow Books, Oxford, pp. 197-214.

Levy, T.E., Najjar, M., Higham, T., Arbel, Y., Muniz, A., Ben-Yosef, E., Smith, N.G., Beherec, M., Gidding, A., Jones, I.W., Frese, D., Smitheram, C., Robinson, M., 2014. Excavations at into the Iron Age archaeolo from the Edom Lowlands Regional Archaeology Project (ELRAP), Vol. 1. Cotsen Institute of Archaeology Press, UCLA, Los Angeles, pp. 89-244.

Liverani, M., 2003. The influence of political institutions on trade in the ancient Near East (Late Bronze to Early Iron Age), in: Zaccagnini, C. (Ed.), Mercanti e politica nel mondo antico. «L'Erma» di Bretschneider, Rome, pp. 119-137.

Liverani, M., 2008. The Late Bronze Age: materials and mechanisms of trade and cultural exchange, in: Aruz, J., Benzel, K., Evans, J.M. (Eds.), Beyond Babylon: Art, Trade, and Diplomacy in the Second Millennium B.C. Yale University Press, New Haven, pp. 161-168.

Lordkipanidze, O., 2001. "Gandzebi" kolkhur brinjaos kulturashi (punktiis depinitsiis da kulturul-sotsiologiuri interpretatsiis tsda) ("Hoards" of the Colchian Bronze Culture (An attempt at functional definition and sociological and ethnocultural interpretation)) Caucasus essays on the archaeology of the Neolithic-Bronze Age: Dedicated to the 80th Birthday of Prof. Otar Japaridze. Center for Archaeological Studies of the Georgian Academy of Sciences, Tbilisi, pp. 178-194.

Lutz, J., Pernicka, E., Wagner, G.A., 1994. Chalkolithische Kupferverhüttung in Murgul, Ostanatolien, in: Wartke, R.-B. (Ed.), Handwerk und Technologie im Alten Orient. Philipp von Zabern, Mainz, pp. 56-66.

Lydolph, P.E., 1985. The climate of the earth. Rowman \& Littlefield, Lanham, MDs.

Maisuradze, B., Gobedzhischvili, G., 2001. Alter Bergbau in Ratscha, in: Gambashidze, I., Hauptmann, A., Slotta, R., Yalçin, Ü. (Eds.), Georgien: Schätze aus dem land des goldenen Vlies. Deutsches Bergbau-Museum, Bochum, pp. 130-135.

Maldonado, B., Rehren, T., 2009. Early copper smelting at Itziparátzico. Journal of Archaeological Science 36, 1998-2006.

Martinón-Torres, M., Killick, D., in press. Archaeological Theories and Archaeological Sciences, in: Gardner, A., Lake, M., Sommer, U. (Eds.), The Oxford handbook of archaeological theory. 
Martinón-Torres, M., Li, X.J., Bevan, A., Xia, Y., Zhao, K., Rehren, T., 2014. Forty thousand arms for a single emperor: from chemical data to the labor organization behind the bronze arrows of the terracotta army. Journal of Archaeological Method and Theory 21, 534-562.

Melikishvili, G.A., 1962. Kulkha (Iz drevney istorii Yuzhnogo Zakabkaz'ya) (Kulkha (from the ancient history of Southern Transcaucasia)), in: Pigulevskaya, H.V., Kallistov, D.P., Katsnelson, I.C., Korostovtsev, M.A. (Eds.), Drevniy mir: Sbornik statey. Izdatel'stvo Vostochnoy Literatury, Moskva, pp. 319-326.

Mikeladze, T.K., 1990. K arkheologii Kolkhidy (On the archaeology of Colchis). Metsniereba, Tbilisi.

Mikeladze, T.K., Khakhutaishvili, D.A., 1985. Drevnekolkhidskoye poseleniye Namcheduri I (The ancient Colchian settlement Namcheduri I). Metsniereba, Tbilisi.

Minar, C.J., Crown, P.L., 2001. Learning and craft production: an introduction. Journal of Anthropological Research 57, 369-380.

Mirau, N.A., 1997. Social context of early ironworking in the Levant, in: Aufrecht, W.A., Mirau, N.A., Gauley, S.W. (Eds.), Urbanism in Antiquity: From Mespotamia to Crete. Sheffield Academic Press, Sheffield, UK, pp. 99-115.

Moon, C.J., Gotsiridze, G., Gugushvili, V., Kekelia, M., Kekelia, S., Migineishvili, R., Otkhmezuri, Z., Özgür, N., 2001. Comparison of the Mineral Deposits between Georgian and Turkish Sectors of the Tethyan Metallogenic Belt, in: Piestrzyński (Ed.), Mineral Deposits at the Beginning of the 21st Century. Swets and Zeitlinger, Lisse, pp. 309-312.

Morse, K., 2003. The nature of gold: an environmental history of the Klondike Gold Rush. University of Washington Press, Seattle, WA.

Mudzhiri, T., 2011. Gornorudnoye Proizvodstvo v Drevney Gruzii (Mining in ancient Georgia). Artlines, Tbilisi.

Muller, J., 1984. Mississippian specialization and salt. American Antiquity 49, 489-507.

Murray, J., 2014. Anchored in time: The date in Apollonius' Argonautica, in: Harder, M.A., Regtuit, R.F., Wakker, G.C. (Eds.), Hellenistic Poetry in Context. Peeters, Leuven, pp. 247-283.

Nazarov, Y.I., 1966. Osobennosti Formirovaniya i Prognoz Glubinnykh (Skrytykh) Mestorozhdeniy Mednokolchedannoy Formatsii Yuzhnoy Gruzii (Particularities of the Formation and Prognosis of Deep (Blind) Ore Deposits of Chalcopyrite Formation of Southern Georgia). Nedra, Moscow.

Olivier, L., Kovacik, J., 2006. The 'briquetage de la Seille' (Lorraine, France): proto-industrial salt production in the European Iron Age. Antiquity 80, 558-566. 
1224 Papuashvili, R., Jibladze, L., 2014. Brinjaos meoradi metalurgiuli sharmoebis tsentri qulevis 1225 namosakhlaridan (A center of secondary metallurgical production at the Qulevi settlement).

1226 Dziebani 22, 178-191.

1227

1228

1229

1230

1231

1232

1233

1234

1235

1236

1237

1238

1239

1240

1241

1242

1243

1244

1245

1246

1247

1248

1249

1250

1251

1252

1253

1254

1255

1256

1257

1258

1259

1260

1261

1262

1263

1264

1265

1266

1267

1268

1269
Peltenburg, E., 1996. From isolation to state formation in Cyprus c. 3500-1500 BC, in:

Karageorghis, V., Michaelidis, D. (Eds.), The development of the Cypriot Economy. From the prehistoric period to the present day. University of Cyprus and the Bank of Cyprus, Nicosia, Cyprus, pp. 45-60.

Perucchetti, L., Bray, P., Dolfini, A., Pollard, A.M., 2015. Physical barriers, cultural connections: Prehistoric metallurgy across the Alpine region. Journal of European Archaeology $18,599-632$.

Pulak, C., 2008. The Uluburun shipwreck and Late Bronze Age trade, in: Aruz, J., Benzel, K., Evans, J.M. (Eds.), Beyond Babylon: art, trade and diplomacy in the second millennium BC. Metropolitan Museum of Art, New York.

Rochette, E.T., 2009. Jade in full: prehispanic domestic production of wealth goods in the middle Montagua Valley, Guatemala. Archaeological Papers of the American Anthropological Association 19, 205-224.

Rothenberg, B., 1987. Pharaonic copper mines in south Sinai. Institute for Archaeometallurgical Studies Newsletter 10/11, 1-7.

Rothenberg, B., 1988. The Egyptian mining temple at Timna. Institute for Archaeo-Metallurgical Studies, Institute of Archaeology, University College London, London.

Rothenberg, B., 1990. The ancient metallurgy of copper: Archaeology, experiment, theory. Institute for Archaeo-Metallurgical Studies, Institute of Archaeology, University College London, London.

Routledge, B., McGeough, K., 2009. Just what collapsed? A network perspective on 'palatial and 'private' trade at Ugarit, in: Bachhuber, C., Roberts, R.G. (Eds.), Forces of transformation: the end of the Bronze Age in the Mediterranean. Oxbow, Oxford, pp. 22-29.

Seeliger, T.C., Pernicka, E., Wagner, G.A., Begemann, F., Schmitt-Strecker, S., Eibner, C., Öztunali, Ö., Baranyi, I., 1985. Archäometallurgische Untersuchungen in Nord- und Ostanatolien. Jahrbuch des Römisch-Germanischen Zentralmuseums Mainz 32, 597-569.

Shaar, R., Lauxe, L., Ben-Yosef, E., Kassianidou, V., Lorentzen, B., Feinberg, J.M., Levy, T.E., 2015. Decadal-scale variations in geomagnetic field intensity from ancient Cypriot slag mounds. Geochemistry, Geophysics, Geosystems 16, 195-214.

Shalev, S., Shilstein, S.S., Yekutieli, Y., 2006. XRF study of archaeological and metallurgical material from an ancient copper-smelting site new Ein-Yahav, Israel. Talanta 70, 909-913. 
Shaw, I., 1998. Exploiting the desert frontier: The logistics and politics of ancient Egyptian mining expeditions, in: Knapp, A.B., Pigott, V.C., Herbert, E.W. (Eds.), Social Approaches to an

Sherratt, S., 1993. Commerce, iron and ideology: metallurgical innovation 12th-11th century Cyprus, in: Karageorghis, V. (Ed.), Cyprus in the 11th century B.C. A. G. Leventis Foundation, Athens, pp. 59-106.

Sherratt, S., 1998. 'Sea Peoples' and the economic structure of the late second millennium in the eastern Mediterranean, in: Gitin, S., Mazar, A., Stern, E. (Eds.), Mediterranean peoples in transition: 13th through early 10th centuries B.C.E. Israel Exploration Society, Jerusalem, pp. 292-313.

South, A., 2012. Tinker, tailor, farmer, miner: metals in the Late Bronze Age economy at Kalavasos, in: Kassianidou, V., Papasavvas, G. (Eds.), Eastern Mediterranean Metallurgy and Metalwork in the Second Millennium BC. Oxbow Books, Oxford, pp. 35-47.

Stark, M.T., 1991. Ceramic production and community specialization: a Kalinga ethnoarchaeological study. World Archaeology 23, 64-78.

Stech, T., 1982. Urban Metallurgy in Late Bronze Age Cyprus, in: Muhly, J.D., Maddin, R., Karageorghis, V. (Eds.), Acta of the International Archaeological Symposium on Early Metallurgy in Cyprus, 4,000-500 BC, Larnaca, Cyprus 1-6 June 1981. Pierides Foundation, Nicosia, pp. 105-115.

Stöllner, T., 2003. Mining and economy - a discussion of spatial oragnizations and structures of early raw material exploitation, in: Stöllner, T., Körlin, G., Steffens, G., Cierny, J. (Eds.), Man and Mining-Mensch und Bergbau: Studies in honor of Gerd Weisgerber on occasion of his 65th birthday. Deutsches Bergbau-Museum, Bochum, pp. 415-446.

Stöllner, T., von Rüden, C., Hanning, E., Lutz, J., Kluwe, S., 2016. The enmeshment of eastern Alpine mining communities in the Bronze Age: From economic networks to Communities of Practice, in: Körlin, G., Prange, M., Stöllner, T., Yalçin, Ü. (Eds.), From bright ores to shiny metals: Festschrift for Andreas Hauptman on the occasion of 40 years research in archaeometallurgy and archaeometry. Deutsches Bergbau-Museum, Bochum, pp. 75-107.

Stos-Gale, Z.A., Maliotis, G., Gale, N.H., Annetts, N., 1997. Lead isotope characteristics of the Cyprus copper ore deposits applied to provenance studies of copper oxhide ingots. Archaeometry 19, 83-123.

Straka, T.J., 2014. Historic charcoal production in the US and forest depletion: Development of production parameters. Advances in Historical Studies 3, 104-114.

Sulava, N., 2001. Letschchumi--eine bedeutende frhe Metallurgie-Region in der Kolchis, in: Gambaschidze, I., Hauptmann, A., Slotta, R., Yalçin, Ü. (Eds.), Georgien: Schätze aus dem land des goldenen Vlies. Deutsches Bergbau-Museum, Bochum, pp. 186-187. 
Sulava, N., 2008. On an small mould discovered in mountainous Colchida, in: Yalçin, Ü., Özbal, H., Paşamehmetoğlu, A.G. (Eds.), Ancient mining in Turkey and the eastern Mediterranean. Atılım University, Ankara, pp. 299-305.

Thornton, C.P., 2009a. The Chalcolithic and Early Bronze Age Metallurgy of Tepe Hissar, Northeast Iran: A Challenge to the 'Levantine Paradigm', Department of Anthropology. University of Pennsylvania, Philadelphia, PA.

Thornton, C.P., 2009b. The emergence of complex metallurgy on the Iranian Plateau: Escaping the Levantine paradigm. Journal of World Prehistory 22, 301-327.

Tolordava, V.A., 1977. Arkheologicheskiye raskopki v Dablagomi v 1973-1974 godakh, in: Lordkipanidze, O. (Ed.), Vani III. Metsniereba, Tbilisi.

Tsetskhladze, G.R., 1995. Did the Greeks go to Colchis for metals? Oxford Journal of Archaeology 14, 307-332.

Tsetskhladze, G.R., 1999. Pichvnari and its environs: 6th c BC-4th c AD. Presses Universitaires Franc-Comtoises, Besançon, France.

Tsetskhladze, G.R., Treister, M.Y., 1995. The metallurgy and production of precious metals in Colchis before and after the arrival of the Ionians (towards the problem of the reasons for Greek colonisation). Bulletin of the Metals Museum 24, 1-32.

Tylecote, R.F., 1982. The Late Bronze Age: copper and bronze metallurgy at Enkomi and Kition, in: Muhly, J.D., Maddin, R., Karageorghis, V. (Eds.), Acta of the International Archaeological Symposium on Early Metallurgy in Cyprus, 4,000-500 BC, Larnaca, Cyprus 1-6 June 1981. Pierides Foundation, Nicosia, pp. 81-100.

Tylecote, R.F., Ghaznavi, H.A., Boydell, P.J., 1977. Partitioning of trace elements between ores, fluxes, slags and metal during the smelting of copper. Journal of Archaeological Science 4, 305333.

Weisgerber, G., 2003. Spatial organization of mining and smelting at Feinan, Jordan: mining archaeology beyond the history of technology, in: Craddock, P., Lang, J. (Eds.), Mining and Metal Production Through the Ages. British Museum Press, London, pp. 76-89.

Wendrich, W., 2013. Archaeology and apprenticeship: body knowledge, identity, and communities of practice, in: Wendrich, W. (Ed.), Archaeology and apprenticeship: body knowledge, identity, and communities of practice. University of Arizona Press, Tucson, AZ, pp. $1-19$.

Wenger, E., 1998. Communities of practice: learning, meaning, and identity. Cambridge 1361 
1362 Wenger, E., 2000. Communities of practice and social learning systems. Organization 7, 2251363246.

1365 Wenger, E.C., Snyder, W.M., 2000. Communities of practice: the organizational frontier.

1366 Harvard Business Review January-February Issue, 139-145.

Wertime, T.A., 1982. Cypriot metallurgy against the backdrop of Mediterranean pyrotechnology: energy reconsidered, in: Muhly, J.D., Maddin, R., Karageorghis, V. (Eds.), Acta of the International Archaeological Symposium on Early Metallurgy in Cyprus, 4,000-500 BC, Larnaca, Cyprus 1-6 June 1981. Pierides Foundation, Nicosia, pp. 351-361.

Wertime, T.A., 1983. The furnace versus the goat: The pyrotechnologic industries and Mediterranean deforestation in Antiquity. Journal of Field Archaeology 10, 445-452.

Yagel, O.A., Ben-Yosef, E., Craddock, a.P.T., 2016. Late Bronze Age copper production in Timna: new evidence from Site 3. Levant 48, 33-51.

Yener, K.A., 2000. The domestication of metals. Brill, Leiden.

Zaccagnini, C., 1990. The transition from bronze to iron in the Near East and the Levant: marginal notes. (A review of Copper production and divine protection: archaeology, ideology and social complexity on Bronze Age Cyprus by A. Bernard Knapp and Early Metallurgy on Cyprus, 4000-500 B. C. edited by James Muhly, Robert Maddin, and Vassos Karageorghis. Journal of the American Oriental Society 110, 493-502.

Zori, C., Tropper, P., Scott, D., 2013. Copper production in late prehispanic northern Chile. Journal of Archaeological Science 40, 1165-1175. 


\section{Appendix A (Supplementary Material). pXRF Methodology for Rapid Qualitative Analysis}

2 of Slag

Qualitative portable X-ray fluorescence (pXRF) analysis of a large number of slags was used to track patterns of ore acquisition and demonstrate lack of coordination in copper mining activities. The analysis focused on measuring the zinc and molybdenum content of the slags as a means of approximating variation of those elements in different ore deposits. While WDS trace

8 element analysis showed cobalt also varies between ore sources, the overlap between the large

$9 \quad \mathrm{Fe} \mathrm{K}_{\beta}$ and the $\mathrm{Co} \mathrm{K}_{\alpha}$ X-ray peaks complicated measurement of Co by pXRF.

While quantitative analyses by $\mathrm{pXRF}$ are possible in certain well-controlled circumstances (Mass and Matsen, 2012; Shugar and Mass, 2012), doing so in this case is both inappropriate and unnecessary. Slags contain significant quantities of low-atomic weight elements, which the pXRF is ineffective at detecting, and standards for the two primary elements of interest, zinc and molybdenum, were unavailable. Moreover, rigorous quantification is unnecessary: the variation in the elements of interest is large and easily detected by qualitative methods alone.

Where possible, the samples were taken from a range of different contexts in order to maximize the likelihood that the sample assemblage reflects many different smelting episodes. Slags from sites with radiocarbon dates were particularly heavily sampled, with 10 sites having 25 or more analyses (Figure A1). Samples were analyzed using a Bruker Tracer III-V with the yellow Ti-Al filter at $40 \mathrm{kV}$ without any vacuum attachment. Current was adjusted to keep counts under about 10,000 cps. Counting times were a minimum of 100 seconds. Where possible the analysis was done on a freshly broken edge or polished section, but for some samples (such as thin slag glazes on ceramics) only surface analyses were possible. Comparison of spectra gathered from a broken edge and the corroded surface of the same sample showed that in qualitative terms, the choice of where to analyze the sample made little difference. In most cases,

27 only a single measurement was necessary, as repeat measurements usually yielded similar results. However, if spectra were qualitatively anomalous or unusual in some way, repeat measurements were done.

Qualitative $\mathrm{pXRF}$ analysis produces an energy spectrum with peaks corresponding to 31 specific elements. The size of the peak is proportional to the amount of that element present in 
32 the sample. Spectra were examined visually and given a preliminary assignment to one of three 33 categories - no peak, a small peak, or a large peak. The primary distinguishing feature was the 34 relative heights of zinc and molybdenum peaks to the copper peaks in the characteristic X-ray 35 spectrum. Classification was made on a relative basis with respect to the peak sizes of that 36 element in the assemblage as a whole, meaning that a sample with "high" Mo was high with 37 respect to the Mo content of the assemblage as a whole. "High" zinc peaks, were generally much 38 larger than "high" molybdenum peaks, as the absolute Zn content of the slags was much greater 39 than the absolute Mo content. Following this initial categorization, a more consistent method of categorization was developed by calculating area-under-the-curve ratios using Artax 7 software.

41 The deconvolution method included the following elements: $\mathrm{K}, \mathrm{Ca}, \mathrm{Ti}, \mathrm{Mn}, \mathrm{Fe}, \mathrm{Co}, \mathrm{Ni}, \mathrm{Cu}, \mathrm{Zn}$, $42 \mathrm{As}, \mathrm{Rb}, \mathrm{Sr}, \mathrm{Zr}, \mathrm{Mo}, \mathrm{Rh}, \mathrm{Sn}, \mathrm{Ba}, \mathrm{W}$, and $\mathrm{Pb}$. Area-under-the-curve ratios between $\mathrm{Zn} / \mathrm{Cu}$ and $43 \mathrm{Mo} / \mathrm{Cu}$ were calculated, correcting for variable count times and rates between samples. $\mathrm{Cu}$ was 44 chosen as the reference, since that element also derived exclusively from the ore source. Next, by reexamination of a number of different spectra and referring back to their original preliminary visual categorization, sharp cut-offs were fixed between categories. This created a rigorous classification system that eliminated any creep in the definition of the categories between spectra collected over a period of several months. In the minority of cases where multiple spectra were measured for a single sample, peak ratios were averaged prior to classification. For the $\mathrm{Zn} / \mathrm{Cu}$ area-under-the-curve categorization, 0.02 was cutoff between "no zinc" and "low zinc," while 1 was the cutoff between "low zinc" and "high zinc." For the $\mathrm{Mo} / \mathrm{Cu}$ area-under-the-curve categorization, 0.06 was cutoff between "no molybdenum" and "low molybdenum," while 0.2 was the cutoff between "low molybdenum" and "high molybdenum."

The sharp and somewhat arbitrary cut-offs for such qualitative classification may invite some skepticism. What if a particular slag was corroded in such a way that it was incorrectly classified? What if the boundaries between categories were incorrectly placed? The coarse qualitative categorization and large sample size mean that the "erroneous" classification of a few 58 borderline samples will not obscure the broader pattern. In any event, the smelting process itself is an imperfect translation of ore mineralogy to slag chemistry, so minor variations have no significance for understanding broader patterns of ore acquisition. Anomalous single measurements were not given great interpretive weight, especially not without reference back to 
62 the original spectra and any accompanying notes taken during analysis. Adjusting of the cut-offs

63 does shift a few samples between categories, but the overall pattern does not change.

\section{List of Figures}

Figure A1. Sample sizes for pXRF analysis.

\section{Caption for table of WDS-XRF chemical analyses included as online supplementary information}

Table S1. Trace element WDS-XRF analyses of copper production slags. Values above 10,000 ppm (1\%) are outside the calibrated range of the instrument, and may not be accurate. Slag types include amorphous spongy slags (A) dense slag cakes (D) and more fluid tap slags (TS). See Erb-Satullo et al. $(2014 ; 2015)$ for a more detailed discussion of slag types and the technology of production. An entry of "nm" means that the element was not measured for that sample.

\section{References}

Erb-Satullo, N.L., Gilmour, B.J.J., Khakhutaishvili, N., 2014. Late Bronze Age and Early Iron Age copper smelting technologies in the South Caucasus: The view from ancient Colchis c. 1500-600 BC. Journal of Archaeological Science 49, 147-159.

Erb-Satullo, N.L., Gilmour, B.J.J., Khakhutaishvili, N., 2015. Crucible technologies in the Late Bronze-Early Iron Age South Caucasus: Copper processing, tin bronze production, and the possibility of local tin ores Journal of Archaeological Science 61, 260-276.

Mass, J.L., Matsen, C., 2012. Quantitative non-destructive analysis of historic silver alloys: Xray fluorescence approaches and challenges, in: Shugar, A., Mass, J.L. (Eds.), Handheld XRF for art and archaeology. Leuvan University Press, Leuven, pp. 215-247. 


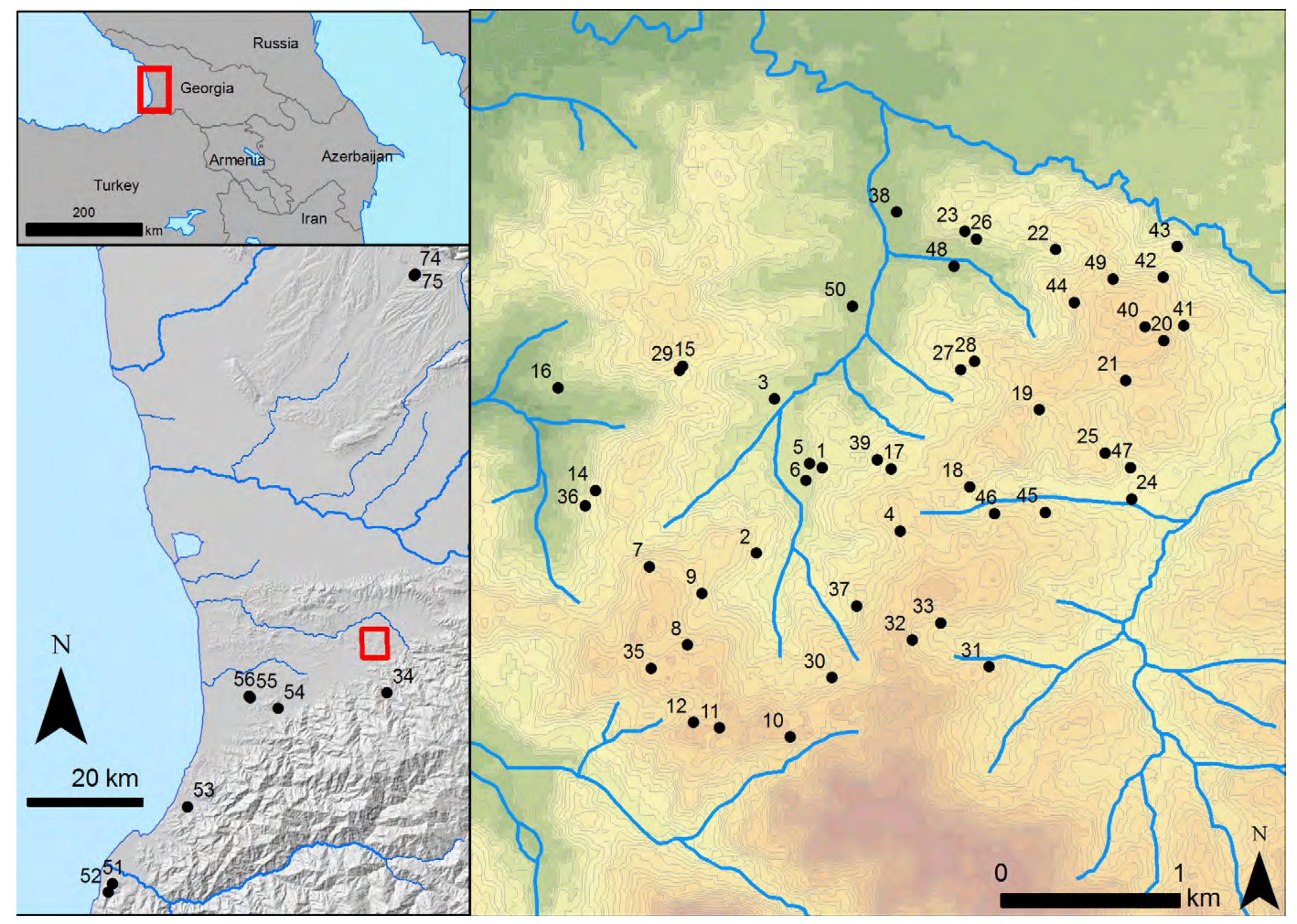




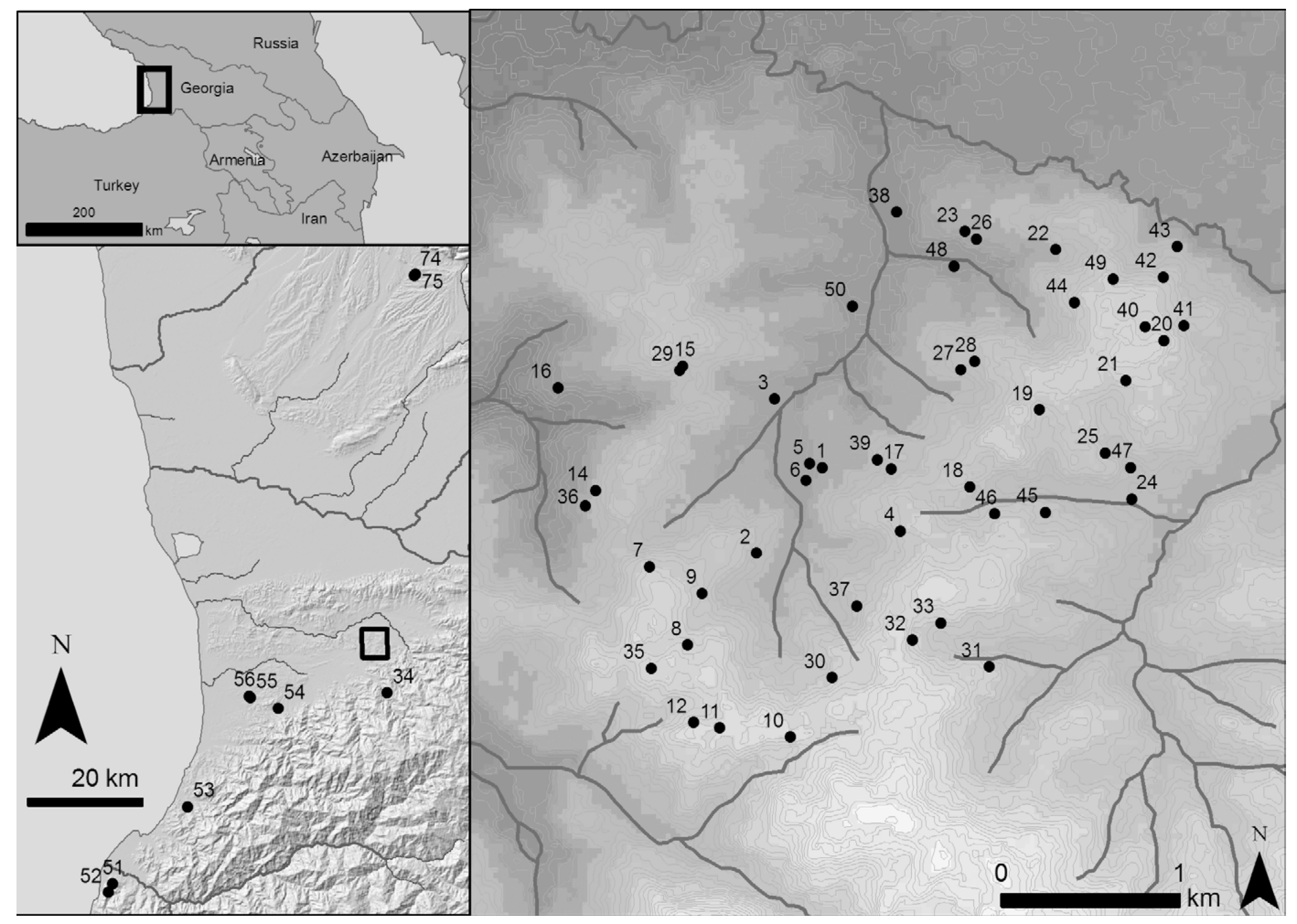




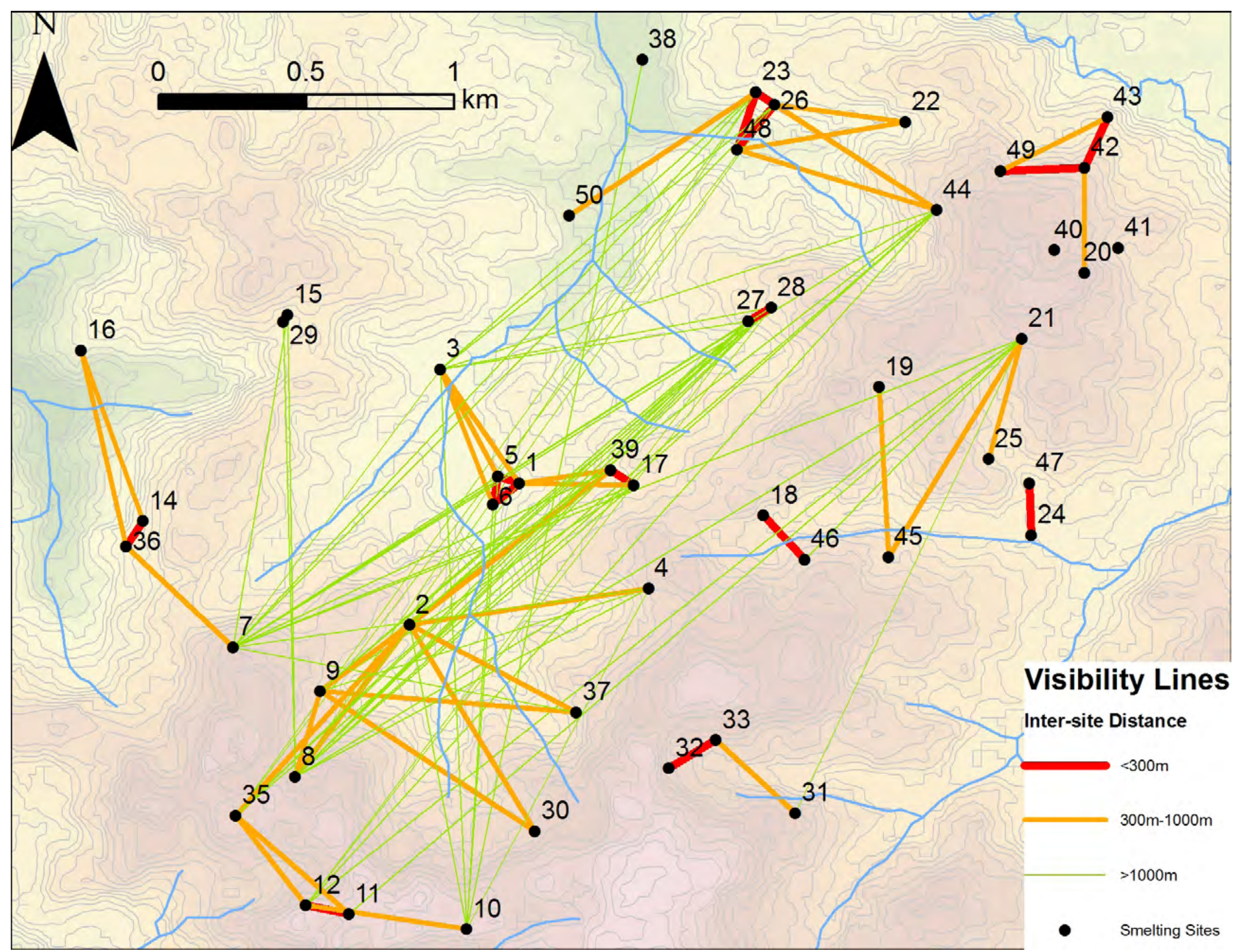




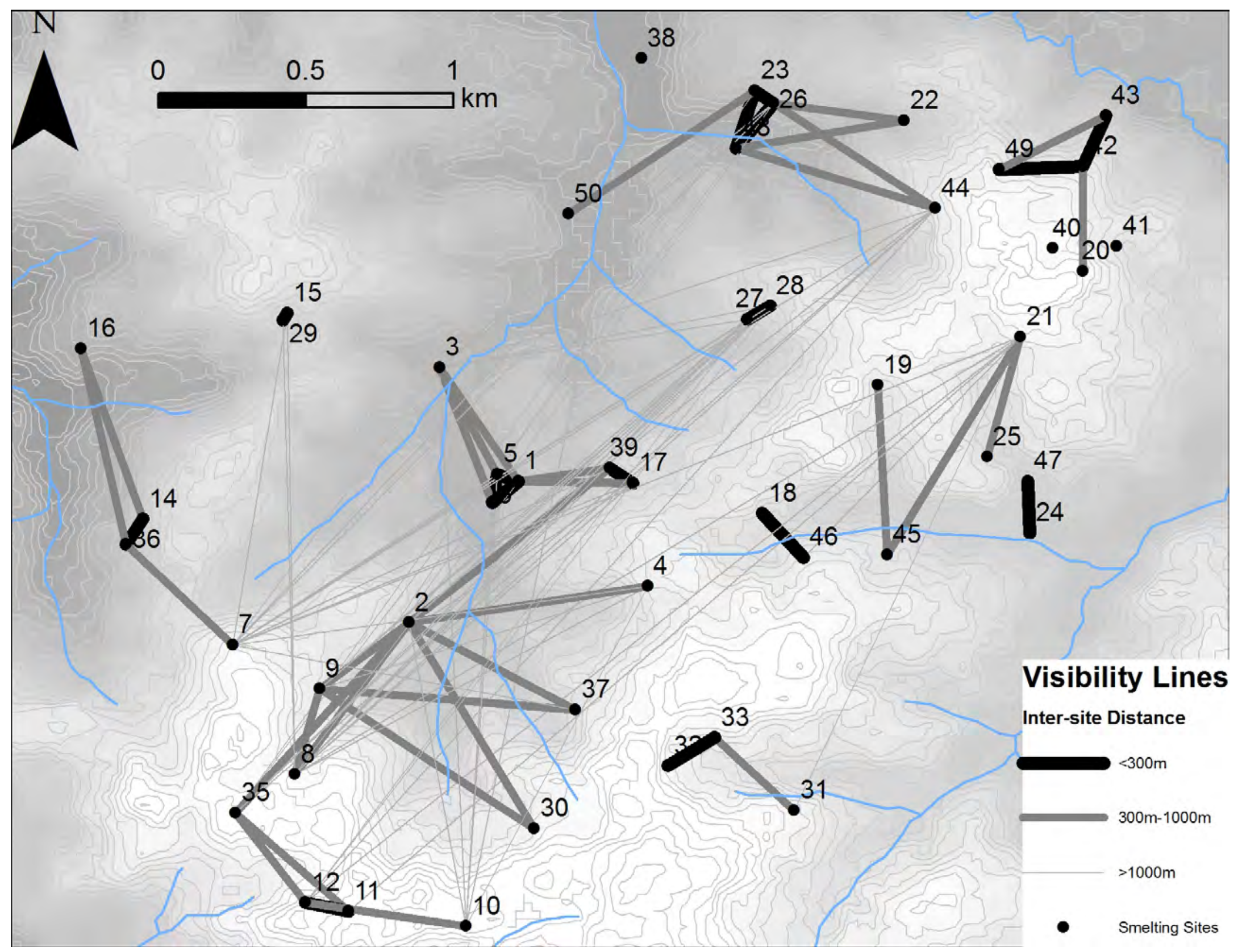




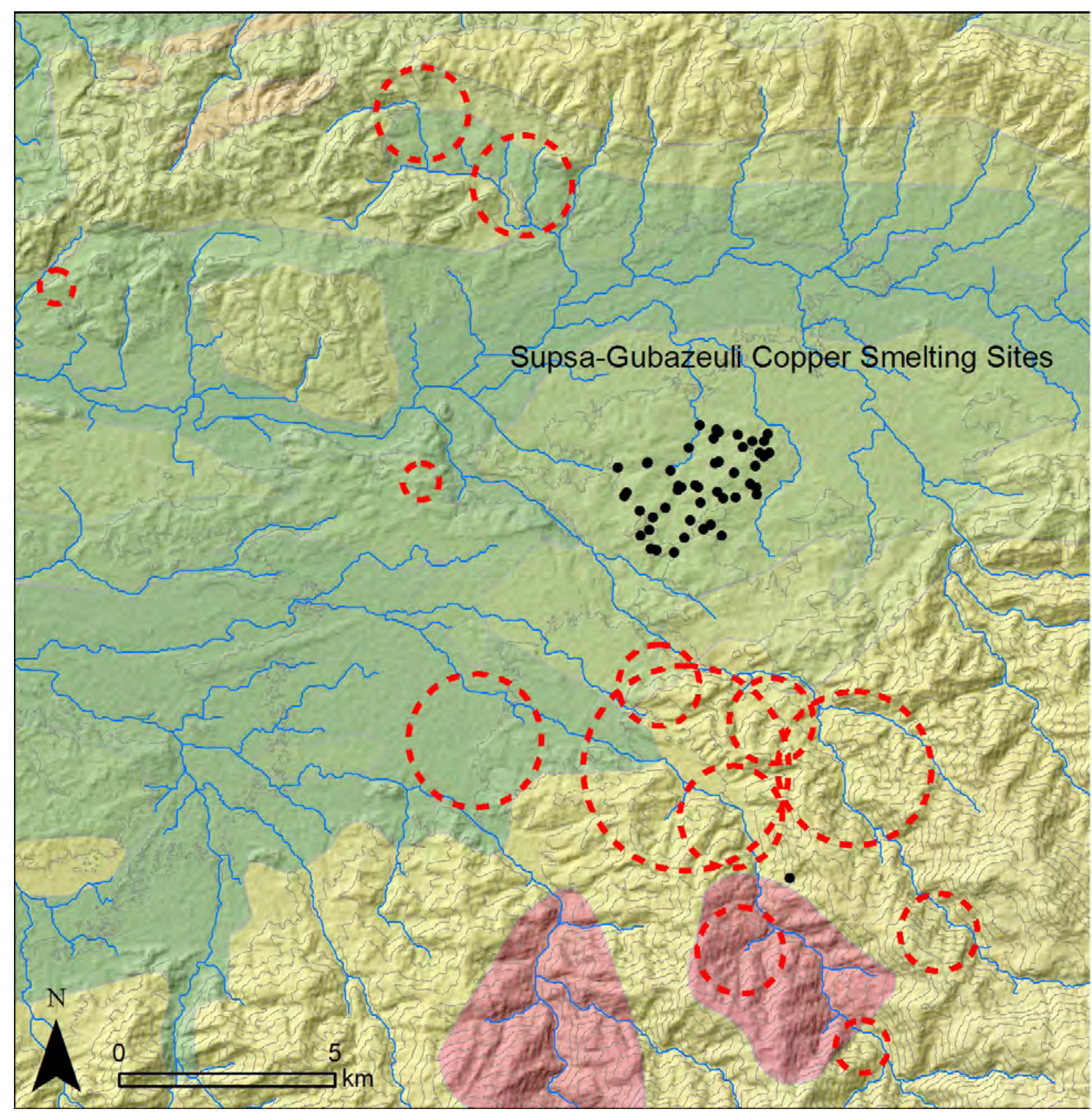

Approximate

I= = - Locations of

I - = I Known Cu

Deposits

Quaternary

Deposits

Upper-Miocene to mid-Quaternary

lavas and

terrigenous

deposits

Oligocene-Lower Miocene sandy-

clayey deposits

Upper Eocene

vulcanogenic

sedimentary

deposits

Middle Eocene

Andesites

Paleocene-Lower

Eocene

sedimentary

volcanogenic

formations

Stock batholith intrusions

(generally

syenites-diorites;

Trialeti Phase) 


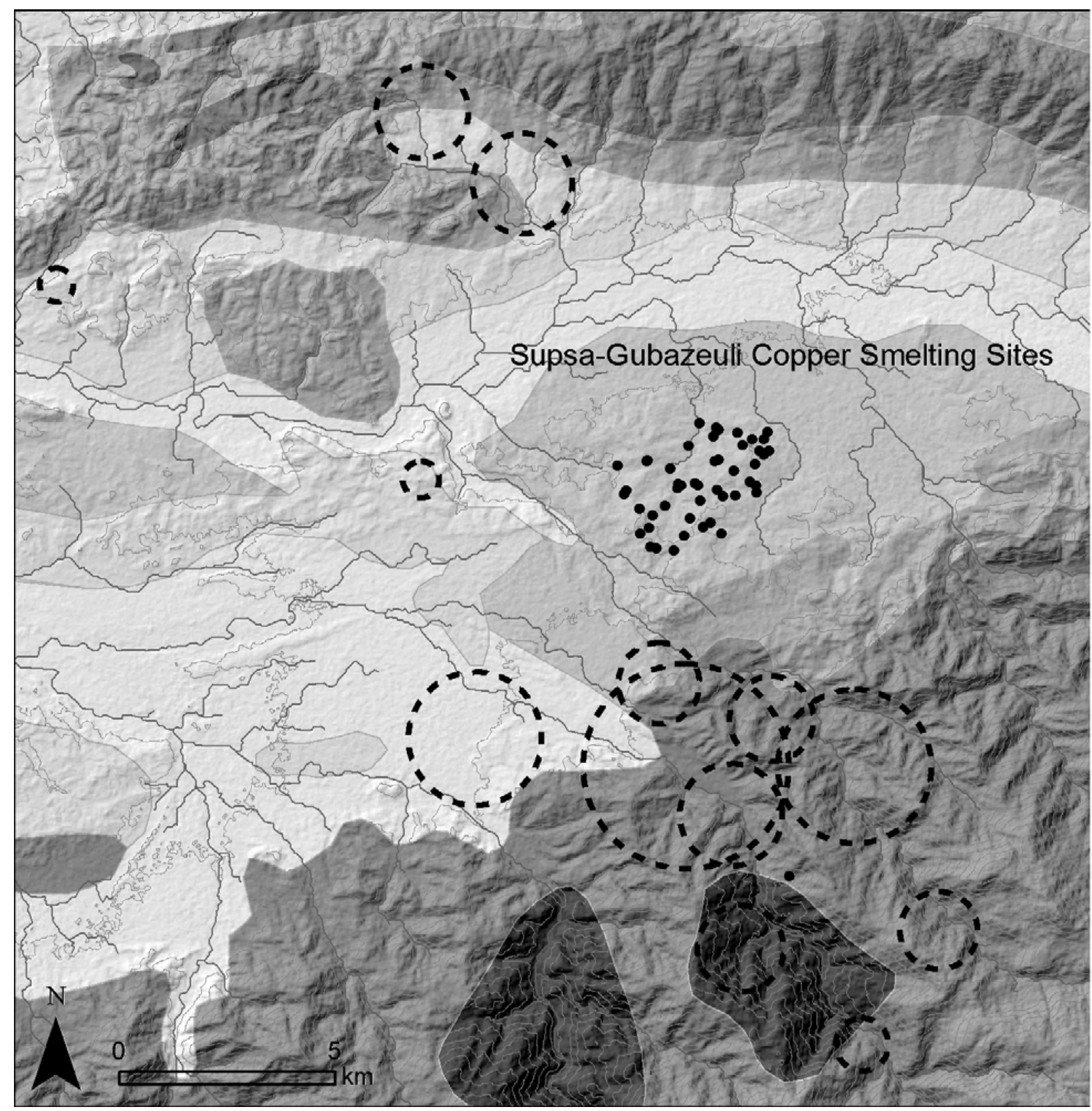

Approximate

I= - - Locations of

I. - - I Known Cu

Deposits

Quaternary

Deposits

Upper-Miocene to mid-Quaternary

lavas and

terrigenous

deposits

Oligocene-Lower Miocene sandy-

clayey deposits

Upper Eocene

vulcanogenic

sedimentary

deposits

Middle Eocene

Andesites

Paleocene-Lower

Eocene

sedimentary

volcanogenic

formations

Stock batholith

intrusions

(generally

syenites-diorites;

Trialeti Phase) 


\section{Ore Deposits}

Copper ore vein with associated zinc minerals

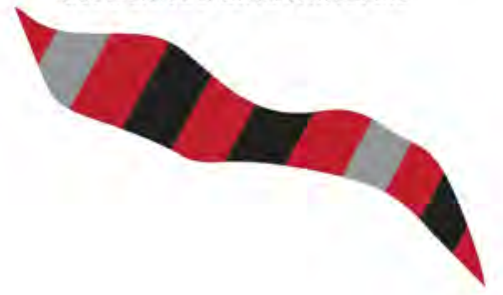

Copper vein without associated zinc minerals

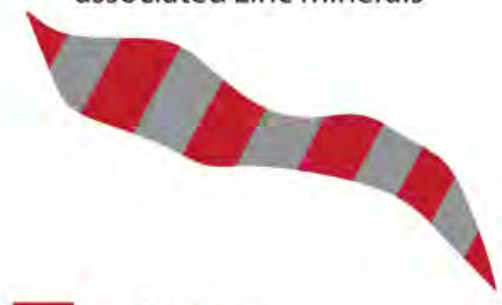

Copper

Zinc

\section{Smelting in Pit Furnace}

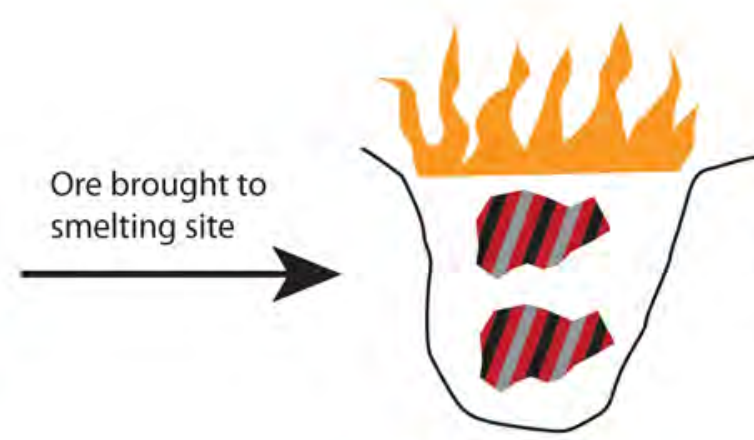

Reduction of metal and formation of slag

$\longrightarrow \sqrt{7}$ Slag (remains at site)

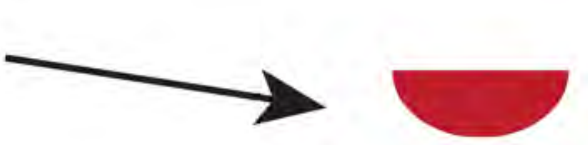

Copper Ingot (removed for fashioning into objects)

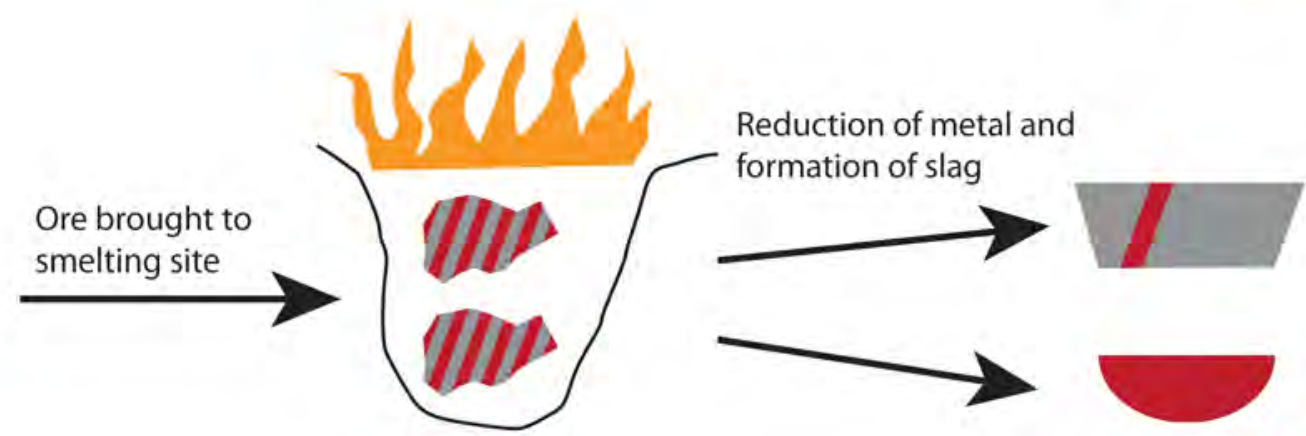

Slag (remains at site)

Copper Ingot (removed for fashioning into objects)

Other ore impurities (mostly silicon, iron, oxygen, sulfur) 


\section{Ore Deposits}

Copper ore vein with associated zinc minerals

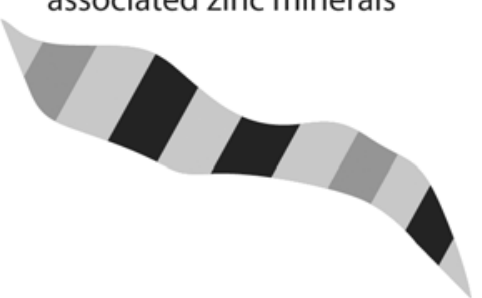

Copper vein without associated zinc minerals

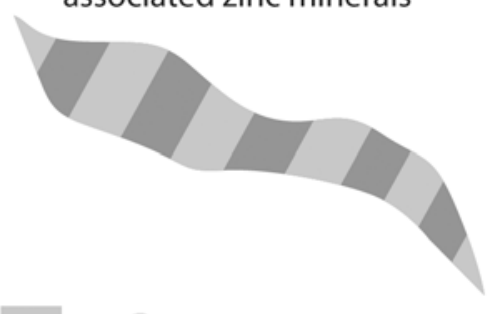

Copper

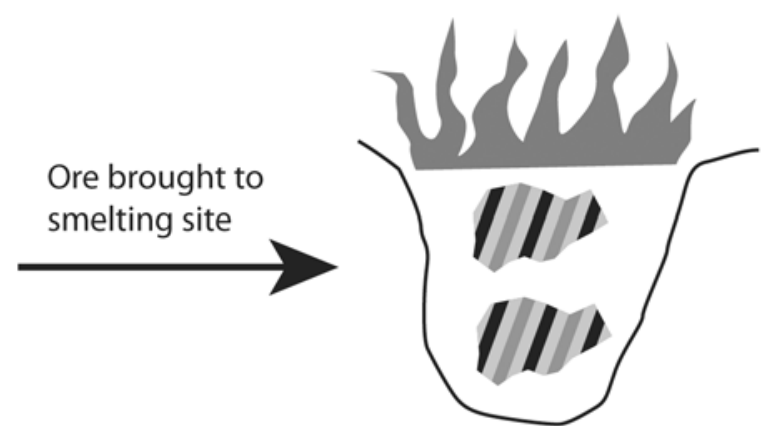

Reduction of metal and formation of slag

$\longrightarrow$ Slag (remains at site)

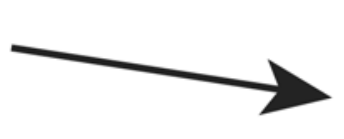

Copper Ingot (removed for fashioning into objects)

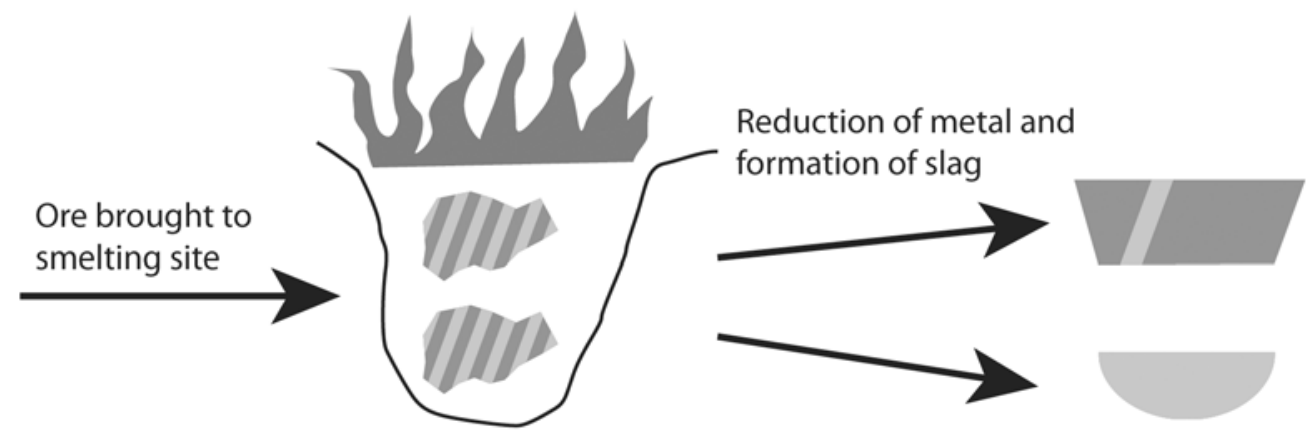

Slag (remains at site)

Copper Ingot (removed for fashioning into objects)

Zinc

Other ore impurities (mostly silicon, iron, oxygen, sulfur) 


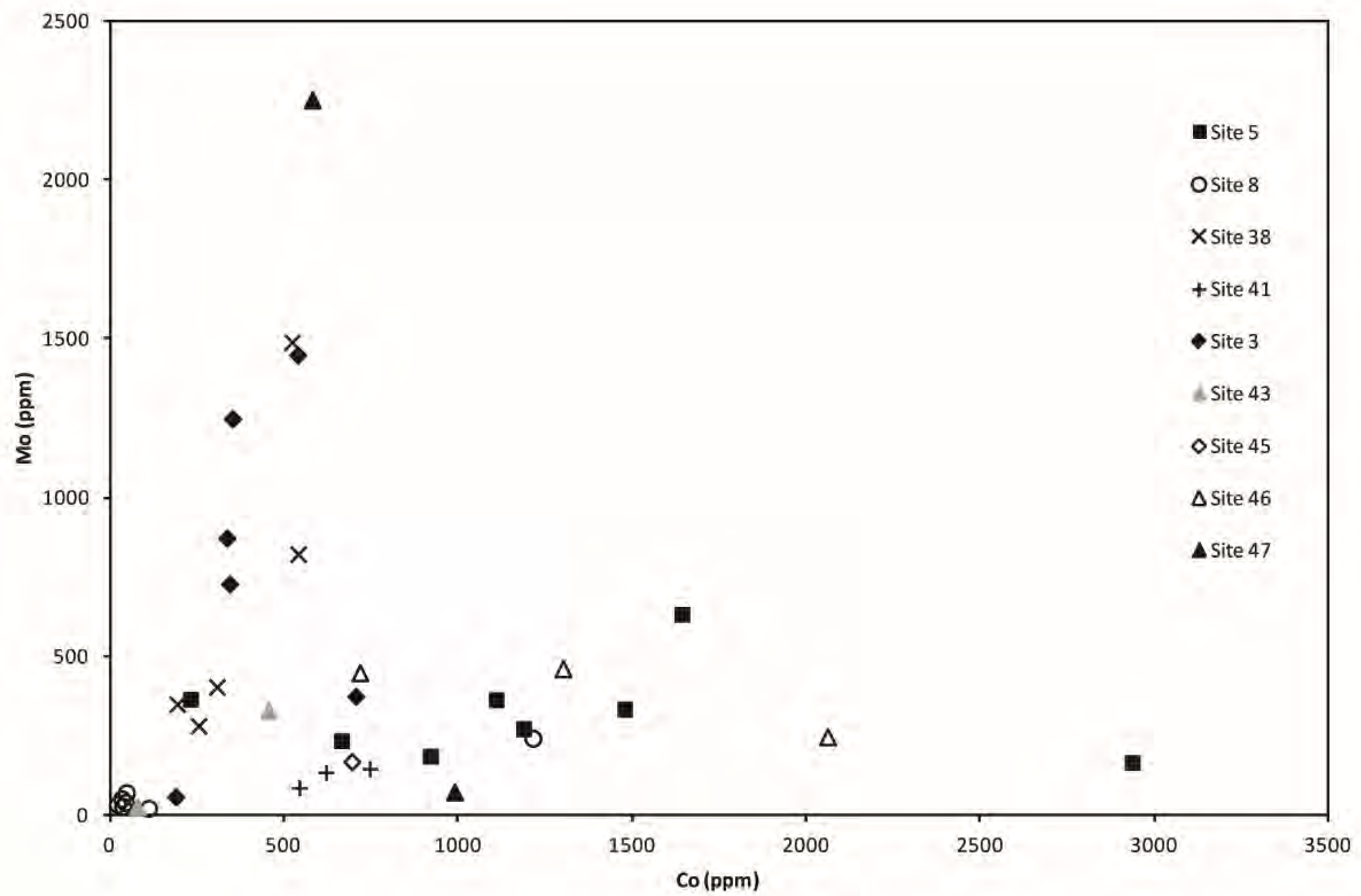


Coordinated Mining Model

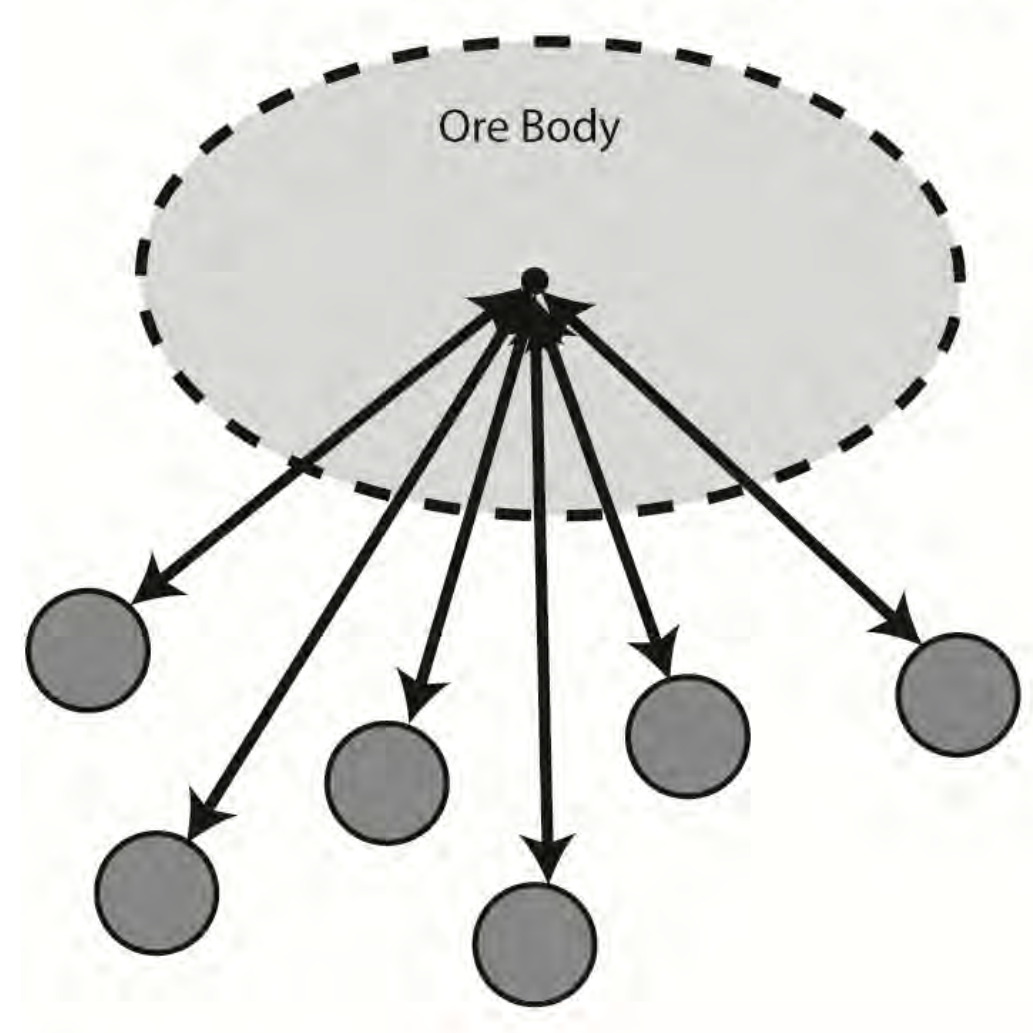

Independent Mining Model

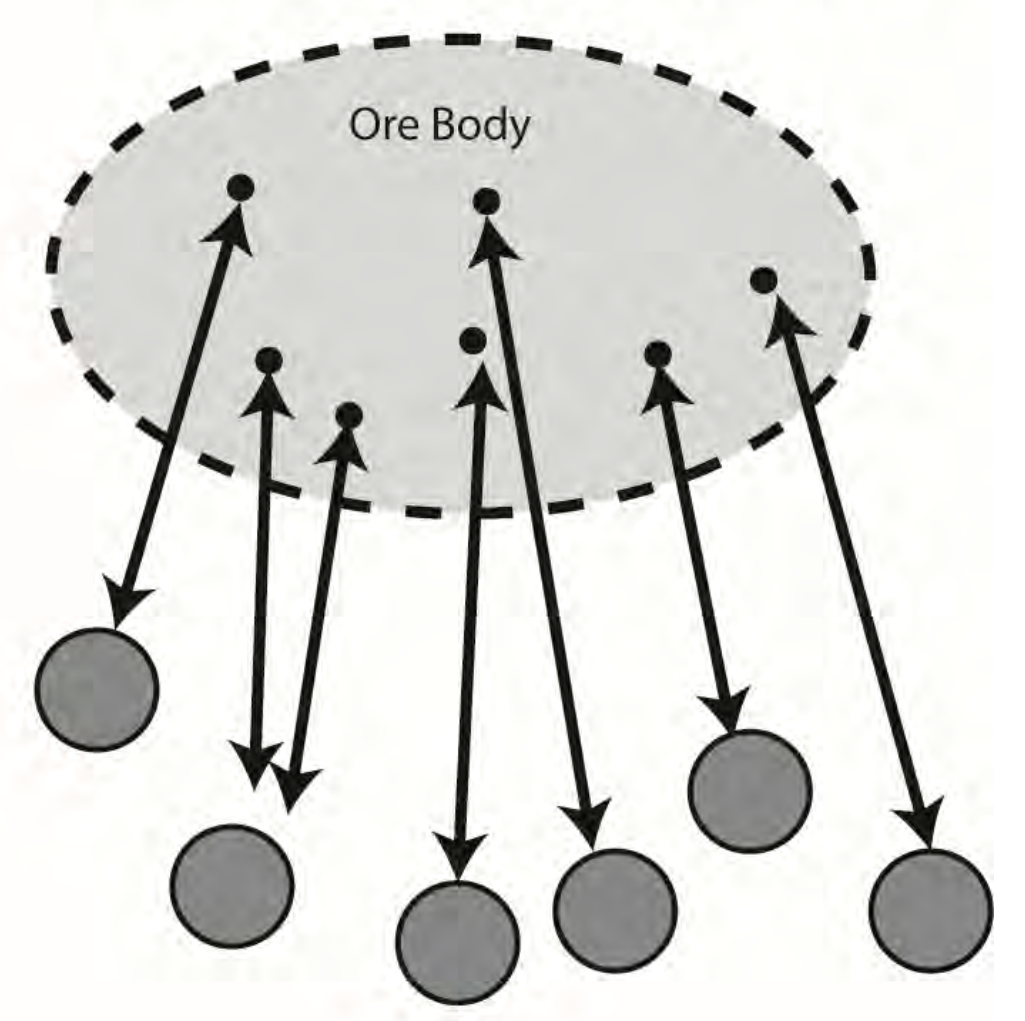

- Mining Site

Smelting Site 

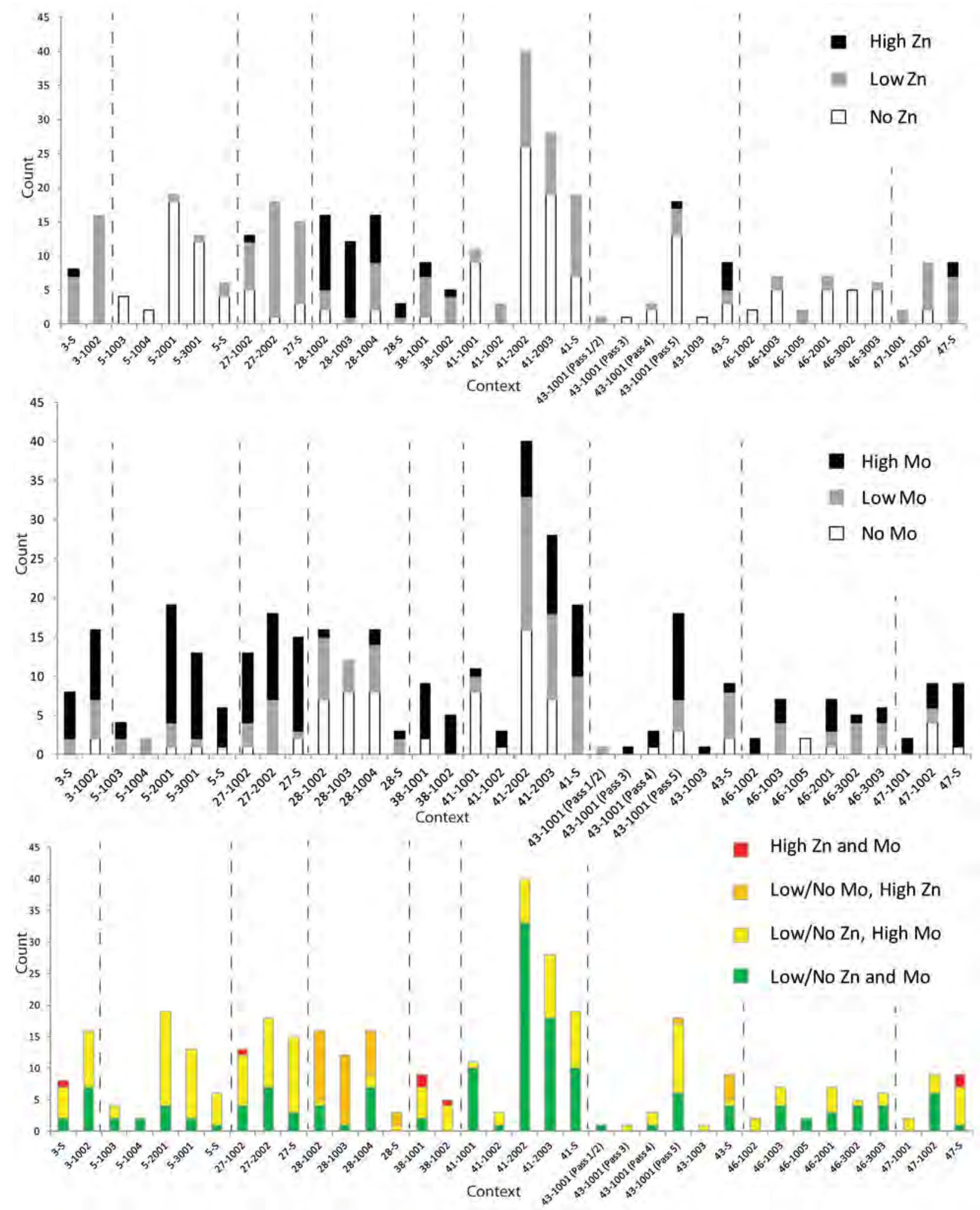

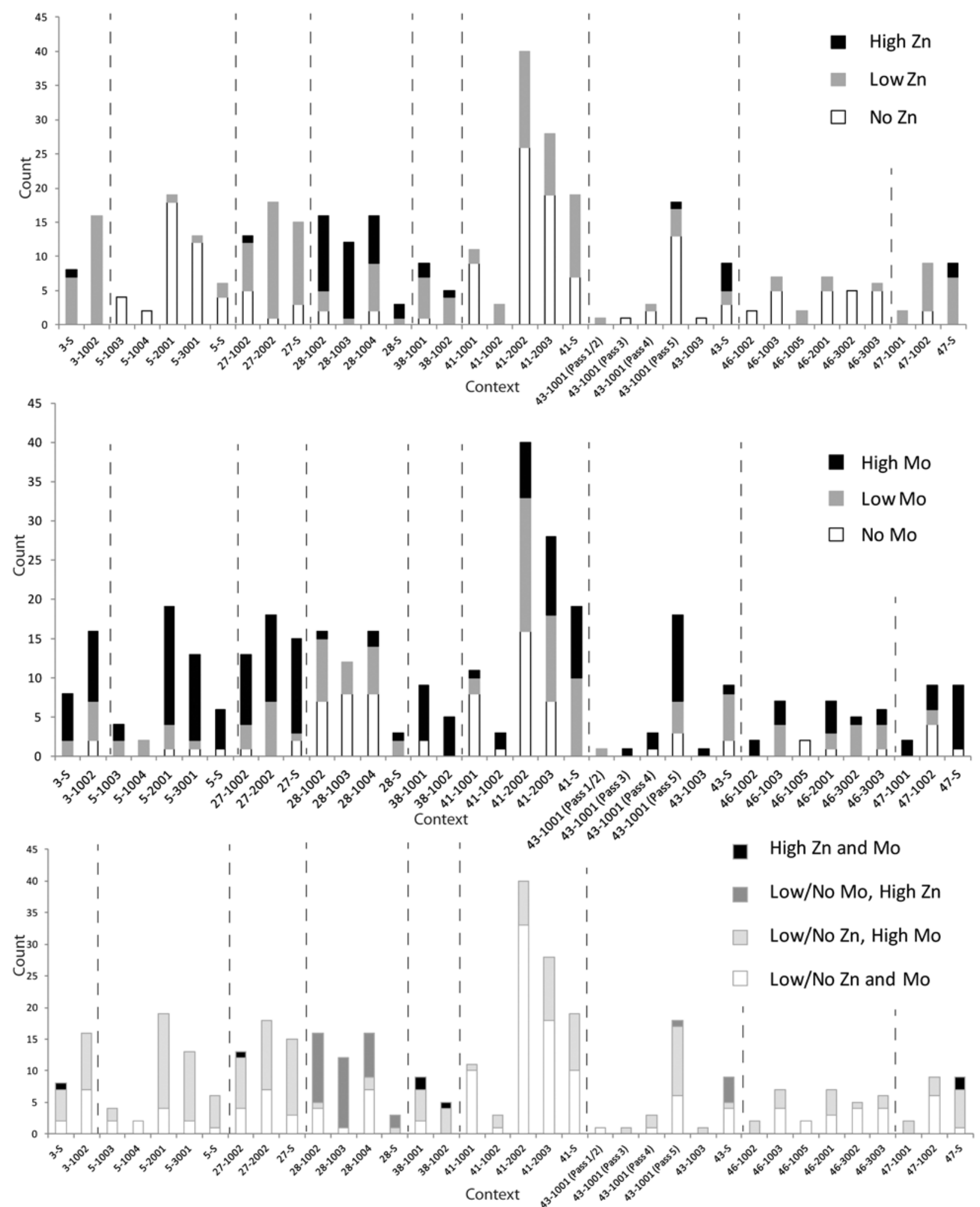


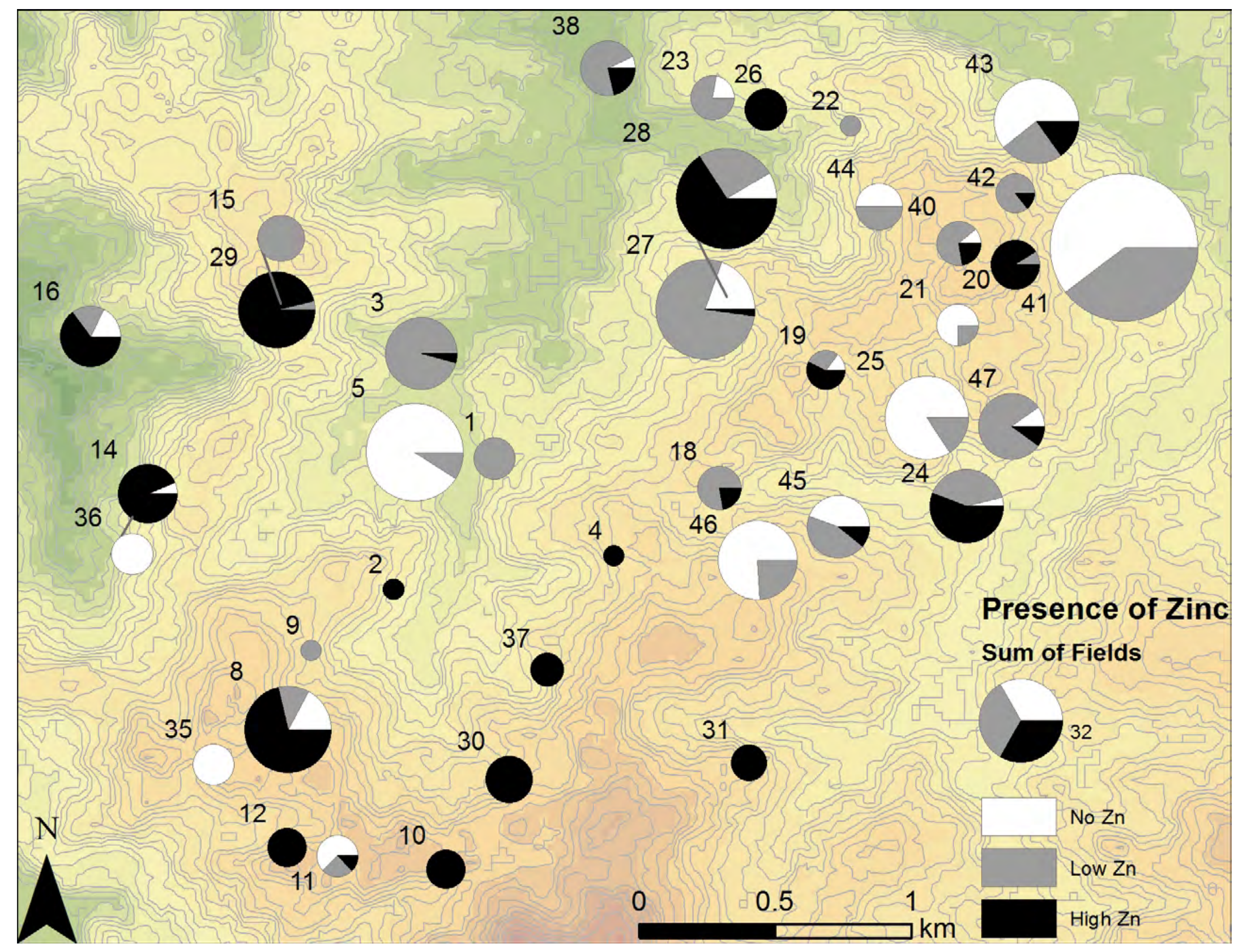




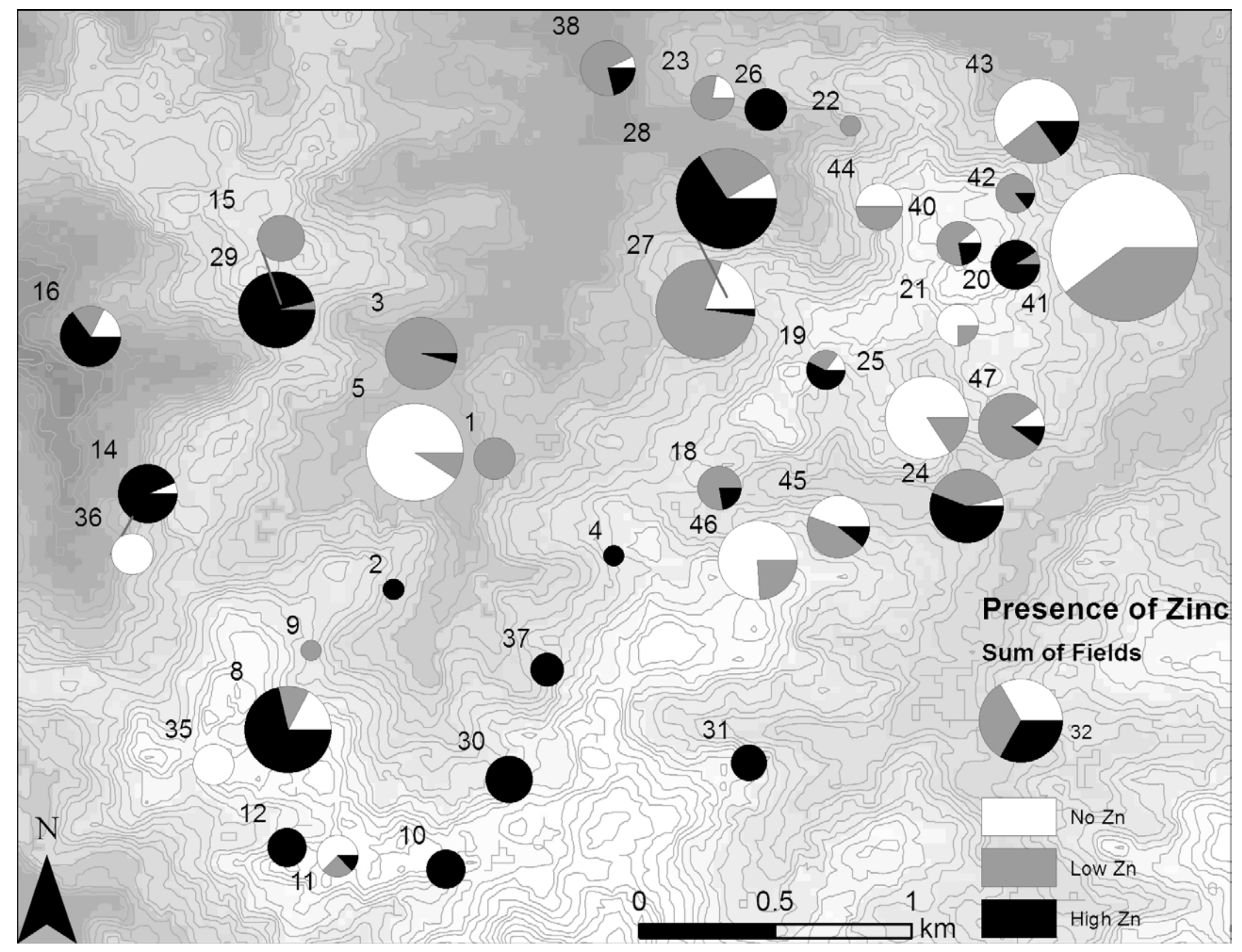




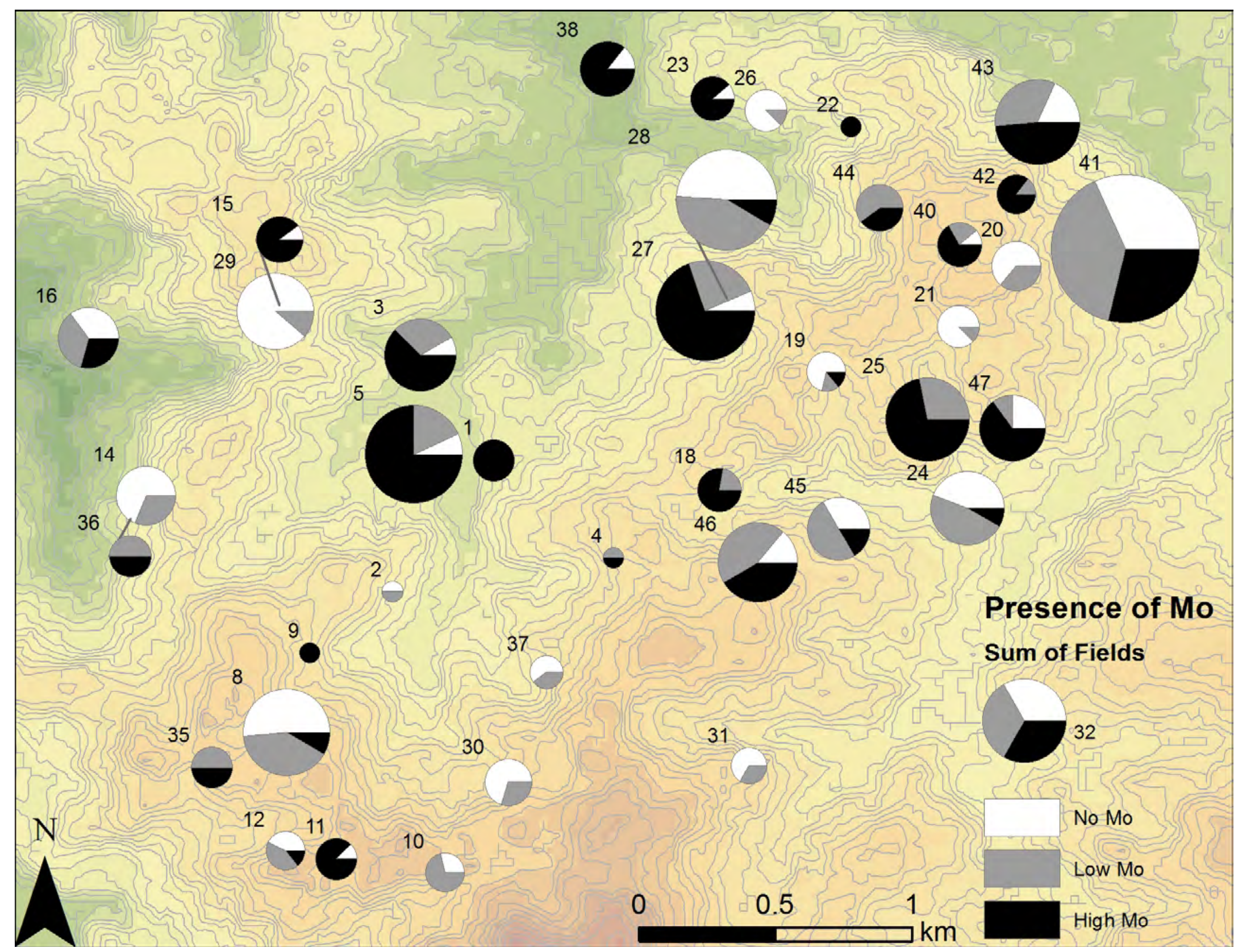




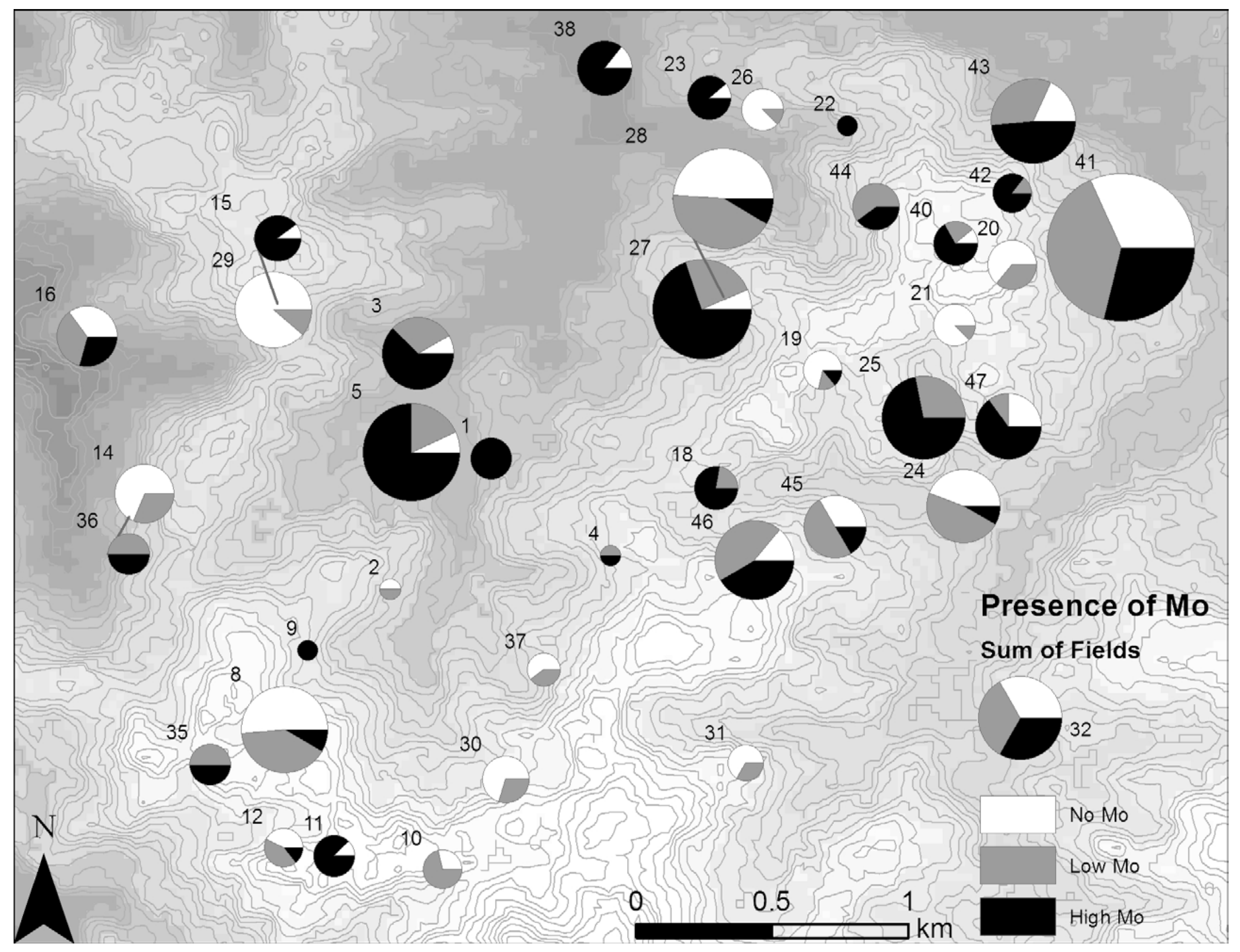




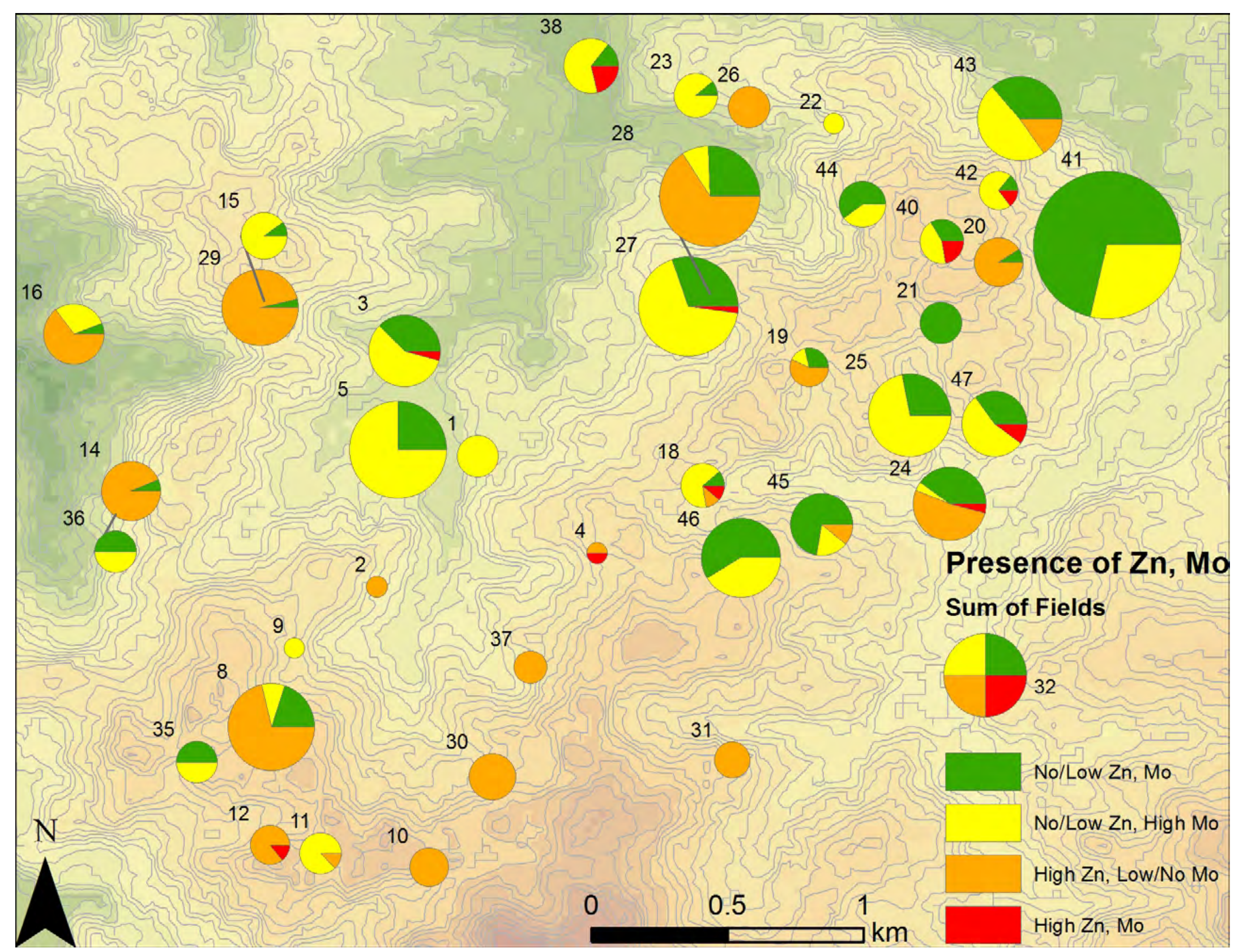




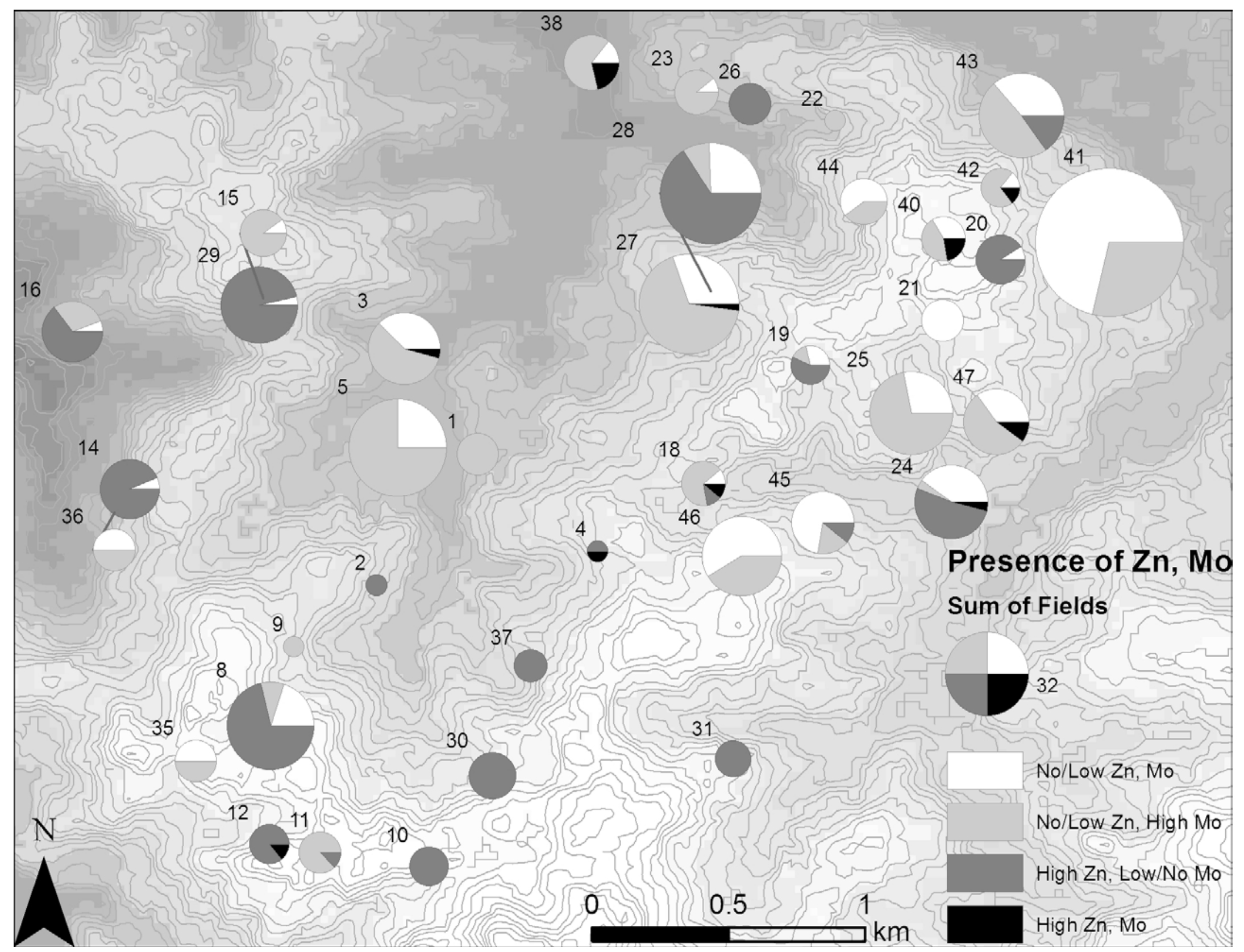




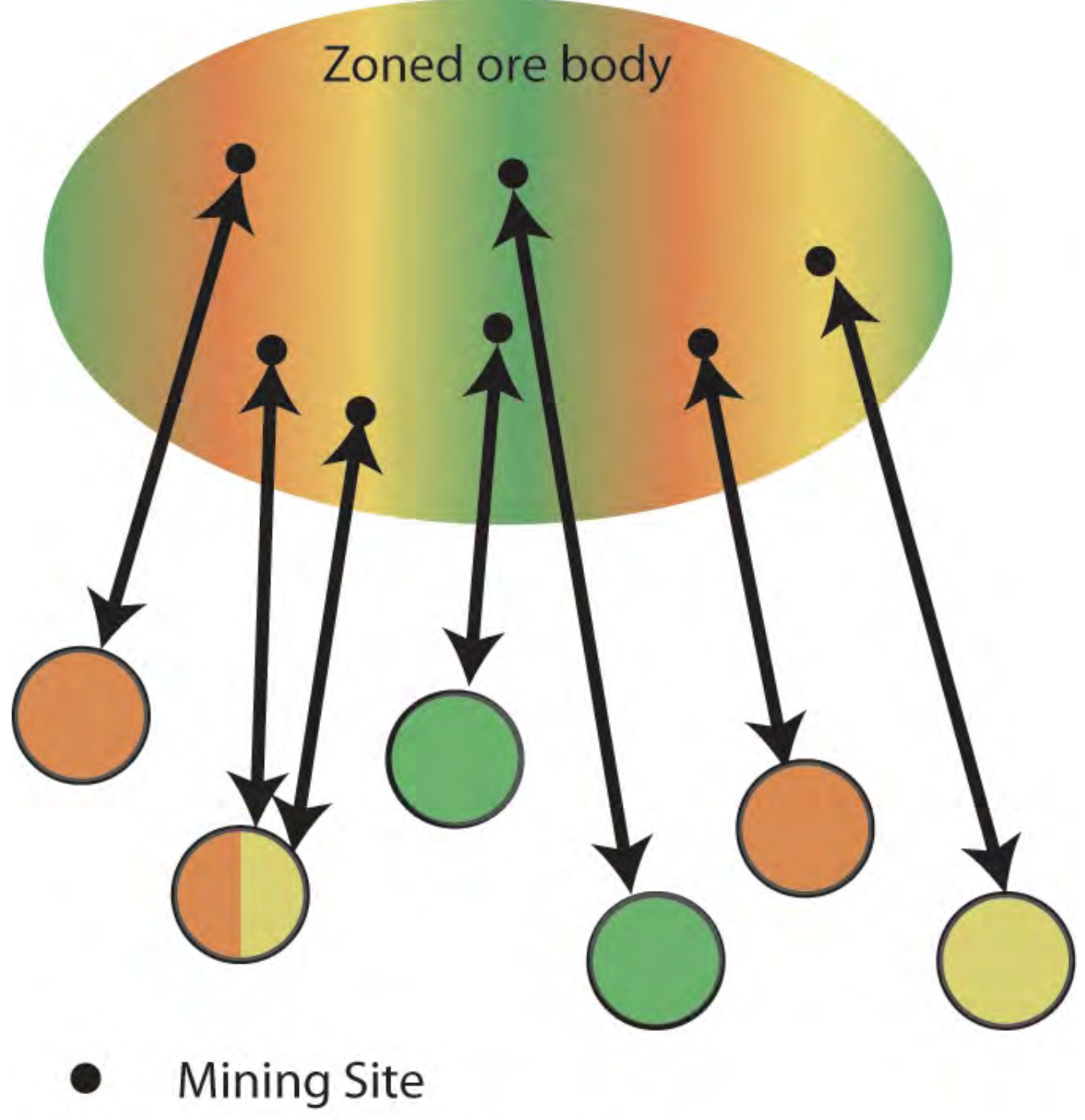

Smelting Site (colored
according to ore type used) 


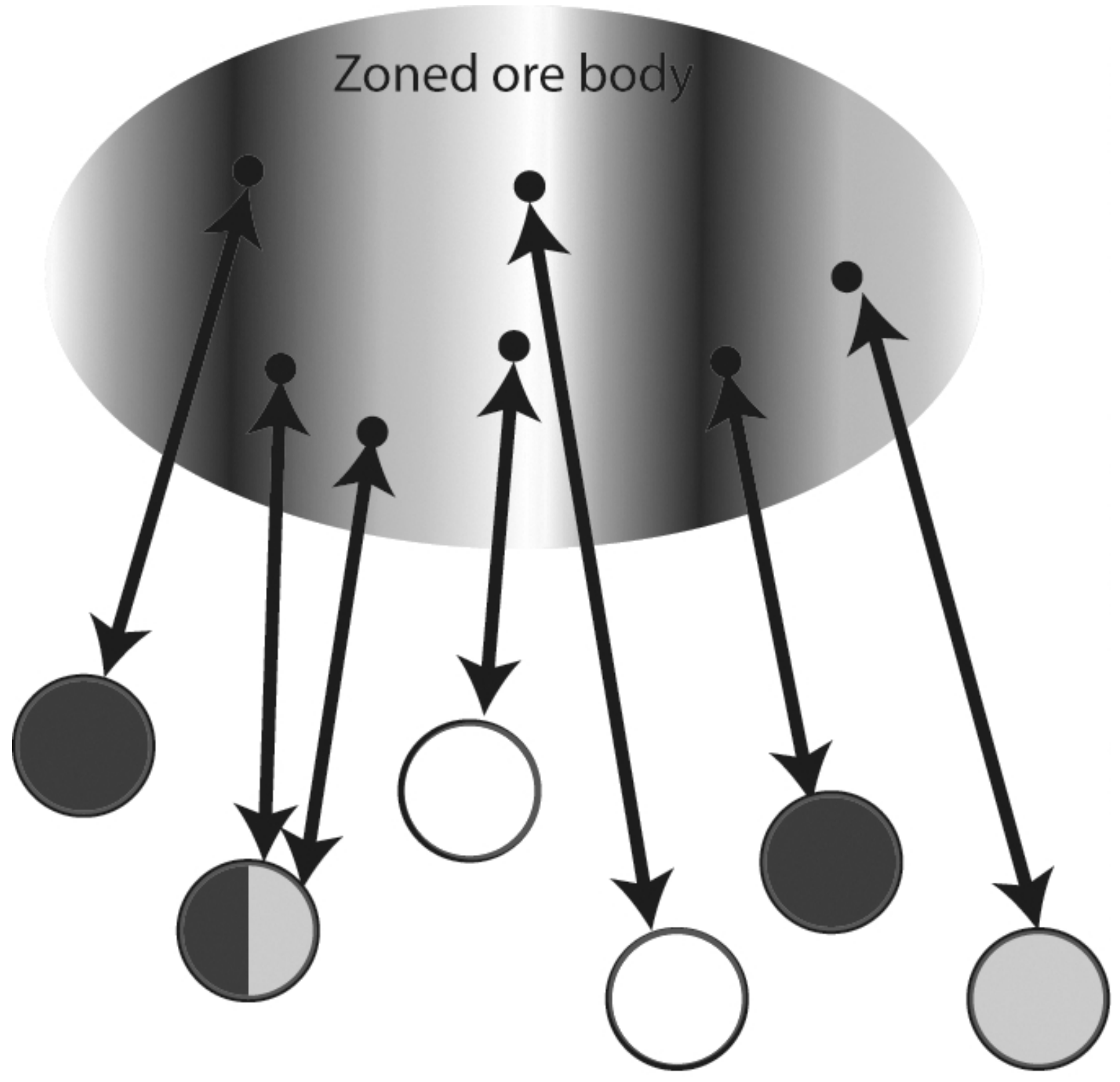

- Mining Site

Smelting Site (colored

according to ore type used) 


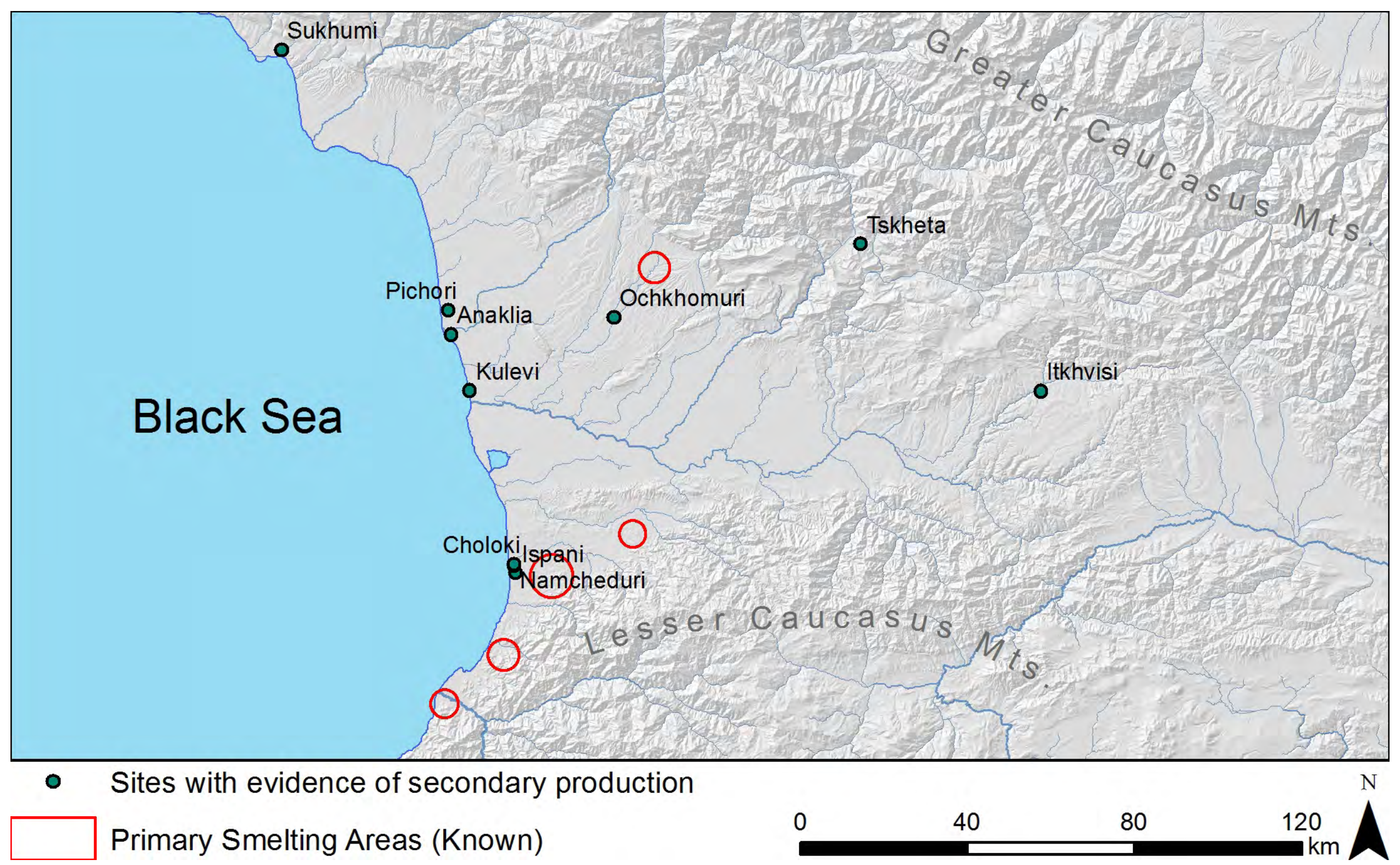




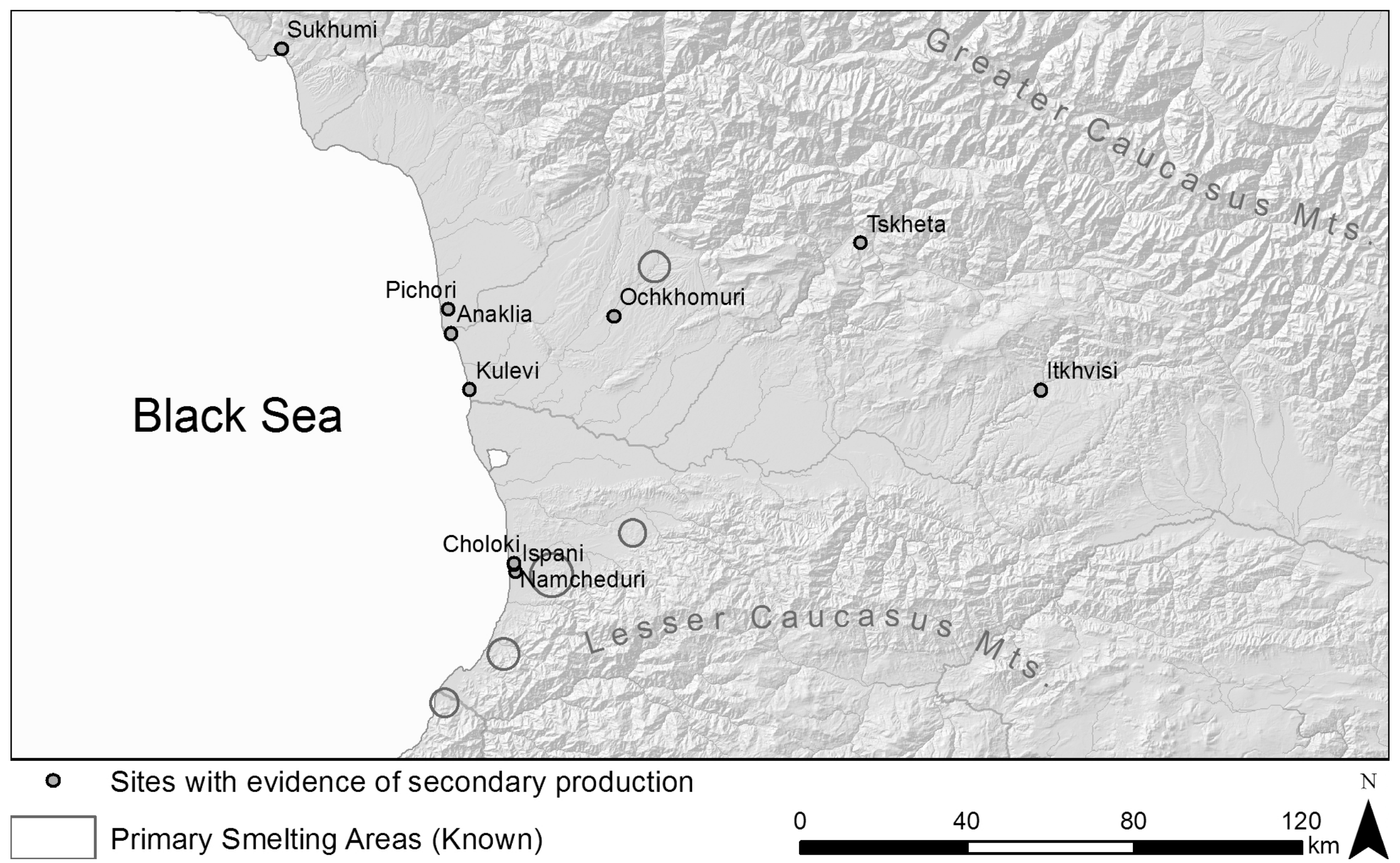




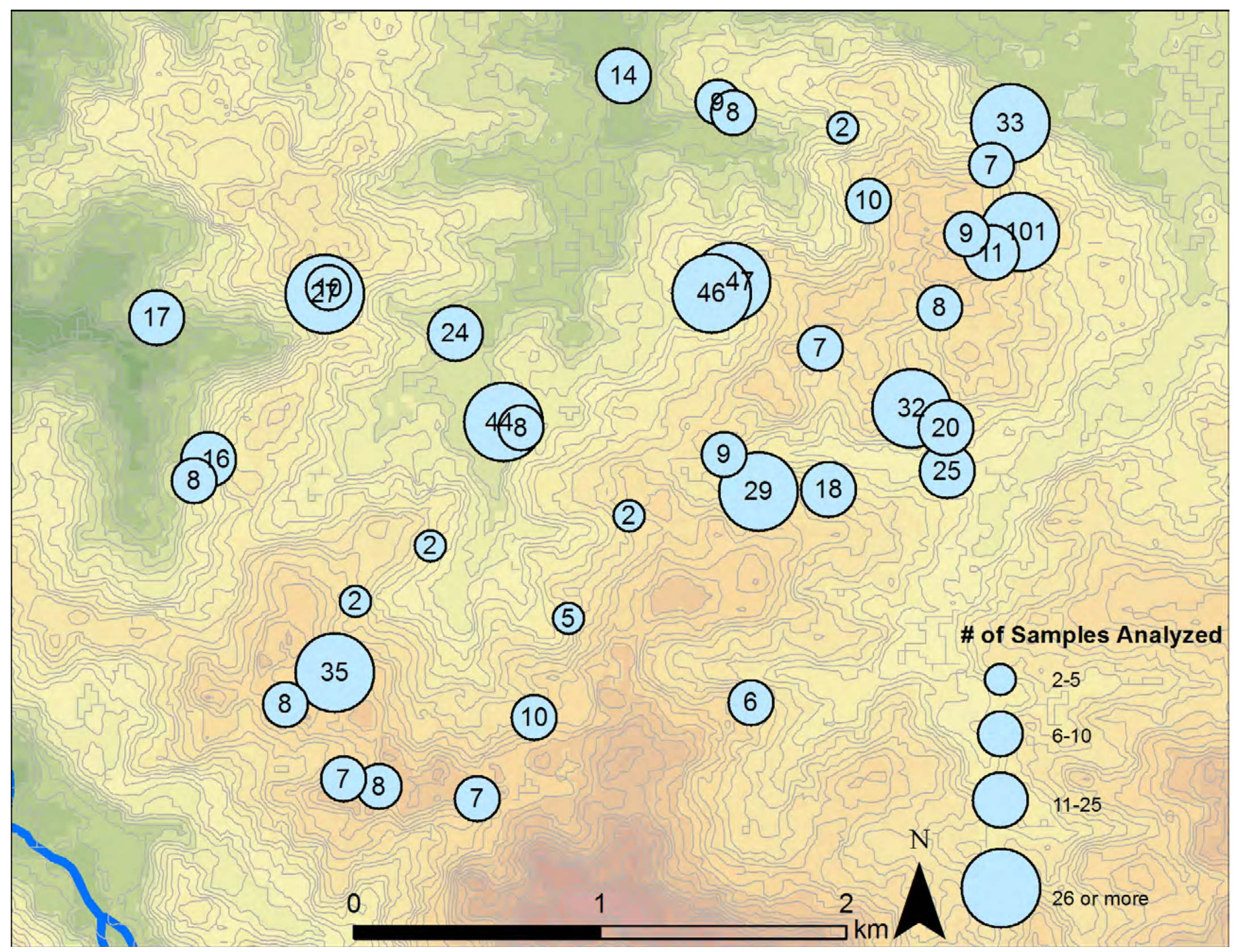


(14)

(8) (2)

(10)

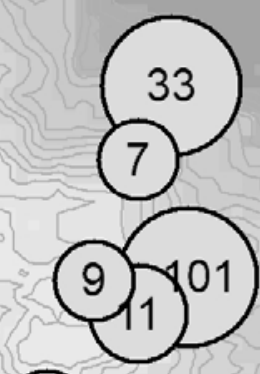

(17) (90)

(24)

(자)

(8)

(7)

(44)

(8)

(2)

(2) (92) 18

(2)

(5)

835

(10)

(6)

\# of Samples Analyzed

(7) 8

(7)

( $2-5$

6-10

$\bigcirc_{11-25}$

0) 1326 or more 


\begin{tabular}{|c|c|c|c|c|c|c|c|c|}
\hline Sample & Jample Typє & $\mathrm{Zn}$ & $\mathrm{Cu}$ & $\mathrm{Ni}$ & Mo & $\mathrm{Nb}$ & $\mathrm{Zr}$ & $\mathrm{Y}$ \\
\hline 301 & $\mathrm{~A}$ & 173 & 5937 & 64 & 59 & 6 & 97 & 23 \\
\hline 302 & A & 995 & 5725 & 70 & 729 & $<5$ & 35 & 30 \\
\hline 303 & $\mathrm{D}$ & 204 & 2377 & 10 & 375 & $<5$ & 77 & 18 \\
\hline 304 & $\mathrm{D}$ & 1238 & 11843 & 121 & 1449 & $<5$ & 20 & 23 \\
\hline 305 & $\mathrm{D}$ & 1407 & 2507 & 40 & 1249 & $<5$ & 1 & 33 \\
\hline 306 & A & 1017 & 9511 & 106 & 873 & $<5$ & 20 & 56 \\
\hline 501 & A & 116 & 3294 & 9 & 184 & $<5$ & 56 & 16 \\
\hline 502 & A & 85 & 3337 & $<5$ & 233 & $<5$ & 58 & 19 \\
\hline 504 & A & 55 & 4165 & 13 & 270 & $<0.5$ & 53 & 14 \\
\hline 506 & $\mathrm{D}$ & 51 & 3463 & 5 & 362 & $<0.5$ & 68 & 19 \\
\hline 508 & D & 49 & 4791 & 43 & 164 & $<0.5$ & 71 & 12 \\
\hline 511 & A & 29 & 3908 & 8 & 363 & $<0.5$ & 69 & 19 \\
\hline 512 & $\mathrm{D}$ & 65 & 9886 & 9 & 332 & $<5$ & 45 & 11 \\
\hline 515 & $\mathrm{D}$ & 45 & 5841 & 14 & 630 & $<0.5$ & 28 & 9 \\
\hline 802 & TS & 99006 & 6136 & 23 & 53 & $<5$ & 64 & 14 \\
\hline 803 & $\mathrm{D}$ & 135861 & 6375 & 35 & 71 & $<5$ & 63 & 3 \\
\hline 805 & A & 70647 & 12626 & 17 & 35 & $<5$ & 53 & 9 \\
\hline 806 & $\mathrm{D}$ & 23811 & 18334 & 14 & 23 & $<5$ & 49 & 6 \\
\hline 810 & TS & 124840 & 5427 & 26 & 41 & $<5$ & 64 & 13 \\
\hline 812 & A & 559 & 4465 & 12 & 243 & $<5$ & 78 & 18 \\
\hline 814 & A & 28499 & 6689 & 7 & 28 & $<5$ & 71 & 13 \\
\hline 3801 & D & 996 & 3437 & 92 & 1490 & $<0.5$ & 32 & 25 \\
\hline 3802 & A & 890 & 8572 & 105 & 823 & $<0.5$ & 34 & 12 \\
\hline 3805 & A & 542 & 7835 & 46 & 350 & $<5$ & 56 & 28 \\
\hline 3807 & A & 842 & 27504 & 108 & 405 & $<5$ & 48 & 19 \\
\hline 3808 & A & 939 & 6382 & 40 & 282 & $<0.5$ & 34 & 14 \\
\hline 4104 & A & 120 & 4512 & 14 & 147 & 7 & 96 & 13 \\
\hline 4105 & D & 1097 & 5724 & 23 & 87 & $<5$ & 70 & 23 \\
\hline 4106 & A & 71 & 3354 & 14 & 135 & $<5$ & 95 & 14 \\
\hline 4303 & D & 135490 & 10895 & 33 & 29 & $<5$ & 46 & 19 \\
\hline 4310 & A & 208 & 13029 & 17 & 331 & $<5$ & 47 & 15 \\
\hline 4504 & A & 161 & 4902 & 9 & 169 & $<0.5$ & 63 & 14 \\
\hline 4602 & A & 66 & 6552 & 18 & 462 & $<0.5$ & 27 & 6 \\
\hline 4604 & A & 78 & 4355 & 7 & 449 & $<0.5$ & 36 & 17 \\
\hline 4607 & D & 38 & 16672 & 51 & 248 & $<0.5$ & 55 & 16 \\
\hline 4701 & A & 163 & 18466 & 46 & 74 & $<5$ & 53 & 22 \\
\hline 4705 & A & 2912 & 5700 & 128 & 2253 & $<5$ & -19 & 37 \\
\hline
\end{tabular}




\begin{tabular}{|c|c|c|c|c|c|c|c|c|}
\hline $\mathrm{Sr}$ & $\mathrm{Rb}$ & $\mathrm{U}$ & Th & $\mathrm{Pb}$ & Co & $\mathrm{Mn}$ & $\mathrm{Cr}$ & V \\
\hline 255 & 82 & $<5$ & $<5$ & 21 & 187 & 2629 & 89 & 509 \\
\hline 240 & 48 & 46 & 9 & 337 & 343 & 2550 & 223 & 276 \\
\hline 578 & 61 & 10 & 3 & 53 & 705 & 1865 & 87 & 175 \\
\hline 205 & 44 & 57 & 19 & 1495 & 538 & 1647 & 194 & 290 \\
\hline 260 & 49 & 78 & 9 & 314 & 351 & 1921 & 126 & 177 \\
\hline 272 & 103 & 83 & 6 & 177 & 335 & 2740 & 107 & 227 \\
\hline 197 & 74 & 5 & 5 & 14 & 922 & 1392 & 130 & 211 \\
\hline 195 & 89 & $<5$ & 5 & 17 & 666 & 1101 & 136 & 204 \\
\hline 123 & 32 & $<1.6$ & 5 & 9 & 1190 & 1064 & 108 & 167 \\
\hline 273 & 68 & 8 & 5 & 7 & 1111 & 1547 & 144 & 172 \\
\hline 292 & 53 & 4 & 2 & 12 & 2939 & 1463 & 80 & 121 \\
\hline 219 & 186 & 10 & 4 & 8 & 232 & 966 & 129 & 148 \\
\hline 143 & 49 & $<5$ & 6 & 9 & 1480 & 1018 & 99 & 178 \\
\hline 123 & 45 & 8 & 8 & 18 & 1645 & 818 & 67 & 148 \\
\hline 323 & 24 & $<5$ & 5 & 239 & 32 & 744 & 29 & 80 \\
\hline 404 & 36 & $<5$ & 5 & 805 & 46 & 871 & 28 & 59 \\
\hline 274 & 17 & $<5$ & 3 & 356 & 20 & 443 & 22 & 50 \\
\hline 226 & 44 & $<5$ & 7 & 108 & 109 & 1583 & 60 & 112 \\
\hline 415 & 21 & $<5$ & 7 & 632 & 43 & 604 & 35 & 110 \\
\hline 279 & 65 & $<5$ & 5 & 25 & 1214 & 1663 & 127 & 202 \\
\hline 298 & 38 & $<5$ & 6 & 478 & 35 & 1279 & 71 & 105 \\
\hline 227 & 54 & 45 & 8 & 147 & 522 & 1990 & 210 & 242 \\
\hline 100 & 25 & 5 & 15 & 1852 & 539 & 1102 & 184 & 315 \\
\hline 203 & 44 & 14 & 8 & 95 & 192 & 1733 & 252 & 334 \\
\hline 162 & 35 & 15 & 14 & 168 & 306 & 1676 & 302 & 348 \\
\hline 159 & 33 & 10 & 5 & 126 & 253 & 1367 & 143 & 309 \\
\hline 761 & 80 & 10 & $<5$ & 38 & 746 & 1116 & 79 & 159 \\
\hline 295 & 45 & $<5$ & 5 & 39 & 543 & 1587 & 125 & 181 \\
\hline 333 & 134 & 5 & 6 & 34 & 619 & 994 & 79 & 177 \\
\hline 235 & 28 & $<5$ & 5 & 1049 & 77 & 1768 & 20 & 52 \\
\hline 249 & 120 & 18 & 5 & 13 & 454 & 1270 & 148 & 204 \\
\hline 251 & 159 & 10 & 4 & 34 & 694 & 849 & 76 & 168 \\
\hline 71 & 44 & 5 & 7 & 21 & 1301 & 811 & 124 & 188 \\
\hline 169 & 51 & 6 & 4 & 11 & 717 & 1902 & 60 & 131 \\
\hline 223 & 51 & $<1.6$ & 4 & 23 & 2061 & 1397 & 66 & 145 \\
\hline 136 & 33 & $<5$ & 6 & 22 & 989 & 1053 & 37 & 68 \\
\hline 248 & 43 & 116 & 13 & 603 & 580 & 1908 & 160 & 179 \\
\hline
\end{tabular}




$\begin{array}{cccccc}\mathrm{F} & \mathrm{S} & \mathrm{Cl} & \mathrm{Sc} & \mathrm{Ba} & \mathrm{Sn} \\ 404 & 449 & 140 & 20 & 782 & \mathrm{~nm} \\ 852 & 808 & 150 & 21 & 2275 & \mathrm{~nm} \\ 531 & 1781 & 133 & 16 & 14930 & \mathrm{~nm} \\ 860 & 592 & 152 & 17 & 2356 & \mathrm{~nm} \\ 963 & 720 & 131 & 18 & 2528 & \mathrm{~nm} \\ 562 & 1977 & 155 & 17 & 1836 & \mathrm{~nm} \\ 1791 & 3172 & 154 & 24 & 799 & \mathrm{~nm} \\ 1484 & 3151 & 227 & 19 & 817 & \mathrm{~nm} \\ \mathrm{~nm} & 3955 & \mathrm{~nm} & 17 & 824 & 13 \\ \mathrm{~nm} & 6131 & \mathrm{~nm} & 17 & 2055 & <2.3 \\ \mathrm{~nm} & 2247 & \mathrm{~nm} & 14 & 2165 & 3 \\ \mathrm{~nm} & 3349 & \mathrm{~nm} & 13 & 1907 & <2.3 \\ 1957 & 6947 & 178 & 18 & 1112 & \mathrm{~nm} \\ \mathrm{~nm} & 5395 & \mathrm{~nm} & 13 & 984 & 16 \\ 591 & 2704 & 101 & <5 & 15477 & \mathrm{~nm} \\ 481 & 1959 & 109 & 8 & 15224 & \mathrm{~nm} \\ <50 & 5597 & 105 & <5 & 14324 & \mathrm{~nm} \\ 1624 & 2561 & 141 & 7 & 2249 & \mathrm{~nm} \\ 516 & 4475 & 107 & <5 & 22320 & \mathrm{~nm} \\ 1359 & 2036 & 204 & 20 & 1853 & \mathrm{~nm} \\ 308 & 3082 & 112 & 6 & 10083 & \mathrm{~nm} \\ \mathrm{~nm} & 3802 & \mathrm{~nm} & 10 & 1595 & <2.3 \\ \mathrm{~nm} & 526 & \mathrm{~nm} & 12 & 1416 & <2.3 \\ 901 & 545 & 129 & 30 & 1457 & \mathrm{~nm} \\ 237 & 1907 & 151 & 31 & 1371 & \mathrm{~nm} \\ \mathrm{~nm} & 691 & \mathrm{~nm} & 17 & 2003 & <2.3 \\ <50 & 1827 & 120 & 11 & 25676 & \mathrm{~nm} \\ 1368 & 1721 & 229 & 22 & 2548 & \mathrm{~nm} \\ 728 & 1030 & 139 & 14 & 4059 & \mathrm{~nm} \\ 1325 & 1601 & 126 & 6 & 6305 & \mathrm{~nm} \\ 600 & 3415 & 160 & 18 & 2929 & \mathrm{~nm} \\ \mathrm{~nm} & 3737 & \mathrm{~nm} & 11 & 2177 & <2.3 \\ \mathrm{~nm} & 3340 & \mathrm{~nm} & 17 & 483 & 14 \\ \mathrm{~nm} & 3586 & \mathrm{~nm} & 12 & 731 & 6 \\ 1647 & 3204 & \mathrm{~nm} & 12 & 1167 & 12 \\ & 1636 & 186 & 7 & 445 & \mathrm{~nm} \\ \mathrm{~nm} & 3277 & 201 & 13 & 5886 & \mathrm{~nm}\end{array}$


- A landscape of many small copper smelting sites was mapped in the South Caucasus.

- Though sites were highly dispersed, metal production was large-scale in aggregate.

- A pXRF survey of nearly 700 slag samples reveal spatial patterns in ore use.

- Spatial and archaeometric data suggest metalworkers lacked top-down coordination.

- This pattern of copper production contrasts with other parts of Western Asia. 